$10 / 28500012$

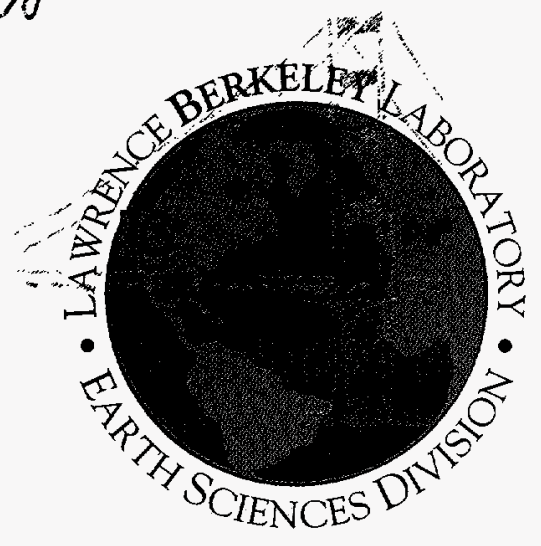

\title{
Preliminary Development of the LBL/USGS Three- Dimensional Site-Scale Model of Yucca Mountain, Nevada
}

\author{
C. Wittwer \\ BRGM 45960 \\ BP 6009
}

Orleans Cedex 2

France

G. Chen and G.S. Bodvarsson

Earth Sciences Division

Lawrence Berkeley Laboratory

University of California

Berkeley, CA 94720

M. Chornack, A. Flint, L. Flint,

E. Kwicklis and R. Spengler

US Geological Survey

Box 25046

Denver Federal Center

Denver, CO 80225

\section{$\boldsymbol{B}$}

June 1995

DISTRIBUTION OF THIS DOCUMENT IS UNLIMITED

This work was prepared under U.S. Department of Energy Contract No. DE-AC03-76SF00098, and DE-A108-78ET44802 administered by the Nevada Operations Office in cooperation with the U.S. Geological Survey, Denver. 


\section{DISCLAIMER}

This document was prepared as an account of work sponsored by the United States Government. While this document is believed to contain correct information, neither the United States Government nor any agency thereof, nor The Regents of the University of California, nor any of their employees, makes any warranty, express or implied, or assumes any legal responsibility for the accuracy, completeness, or usefulness of any information, apparatus, product, or process disclosed, or represents that its use would not infringe privately owned rights. Reference herein to any specific commercial product, process, or service by its trade name, trademark, manufacturer, or otherwise, does not necessarily constitute or imply its endorsement, recommendation, or favoring by the United States Government or any agency thereof, or The Regents of the University of California. The views and opinions of authors expressed herein do not necessarily state or reflect those of the United States Government or any agency thereof, or The Regents of the University of California.

Lawrence Berkeley Laboratory is an equal opportunity employer. 


\title{
Preliminary Development of the LBL/USGS Three-Dimensional Site-Scale Model of Yucca Mountain, Nevada
}

\author{
C. Wittwer \\ BRGM 45960 \\ BP 6009 \\ Orleans Cedex 2 \\ France \\ G. Chen and G.S. Bodvarsson \\ Earth Sciences Division \\ Lawrence Berkeley Laboratory \\ University of California \\ Berkeley, CA 94720
}

M. Chornack, A. Flint, L. Flint, E. Kwicklis and R. Spengler

US Geologic Survey

Box 25046

Denver Federal Center

Denver, CO 80225

June 1995

This work was prepared under U.S. Department of Energy Contract No. DE-AC03-76SF00098, and DE-A108-78ET44802 administered by the Nevada Operations Office in cooperation with the U.S. Geological Survey, Denver.

\section{MASTER}




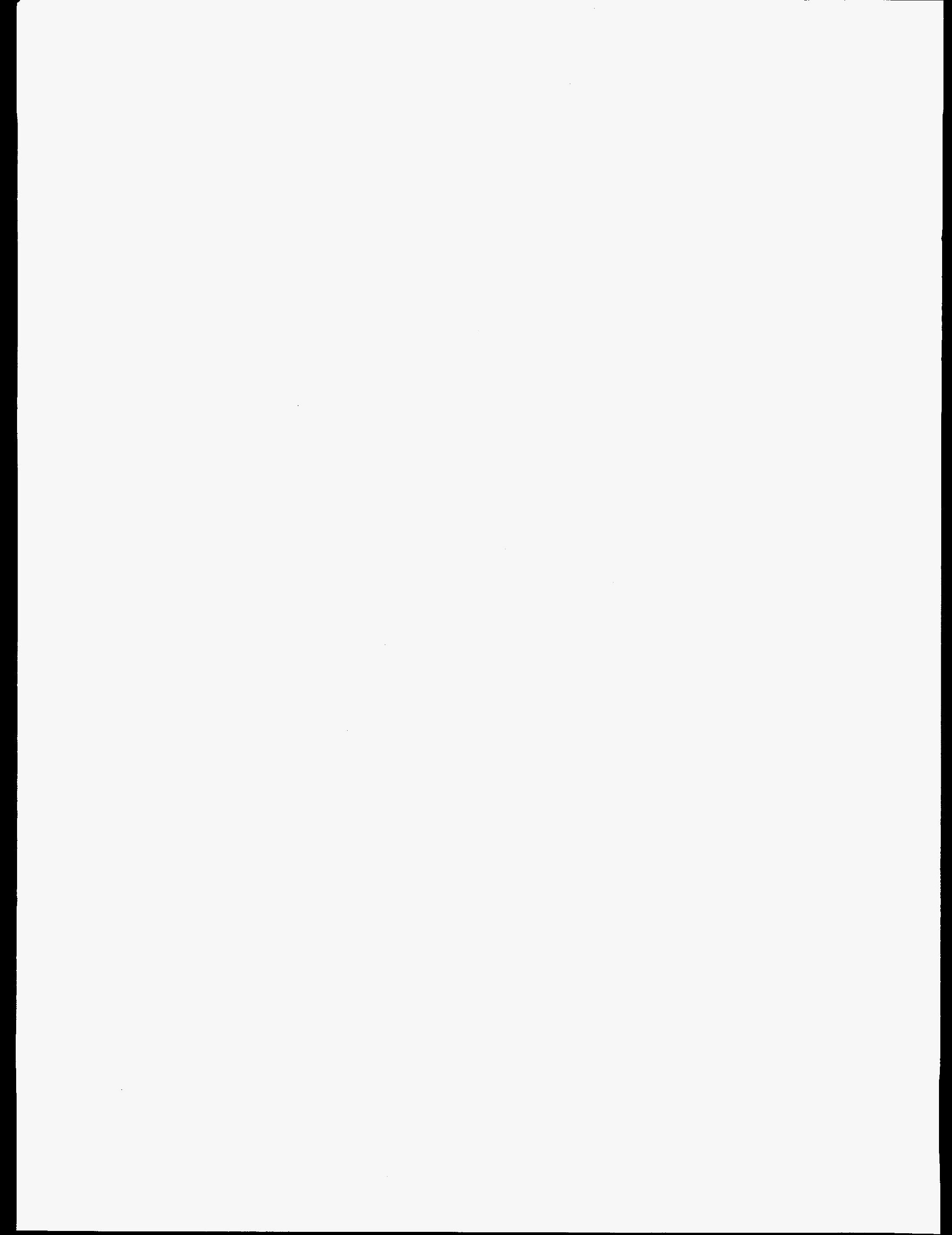




\section{DISCLAIMER}

Portions of this document may be illegible in electronic image products. Images are produced from the best available original document. 


\section{Table of Contents}

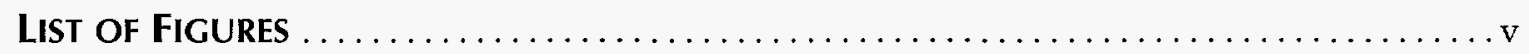

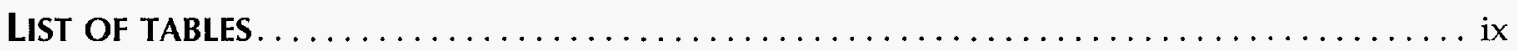

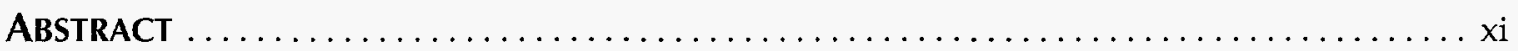

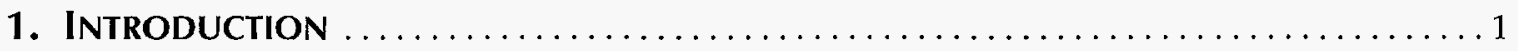

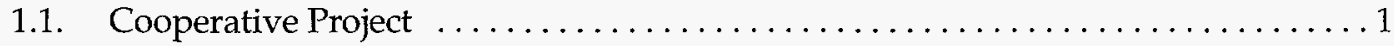

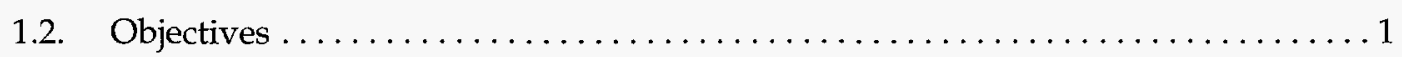

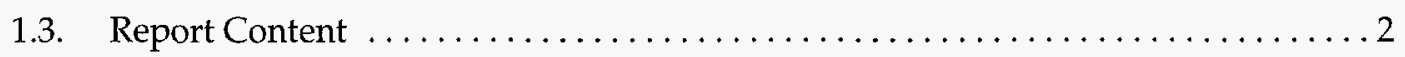

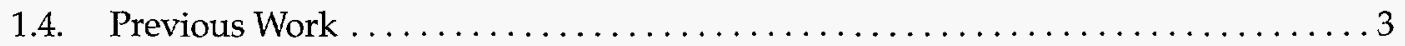

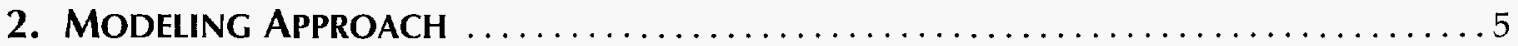

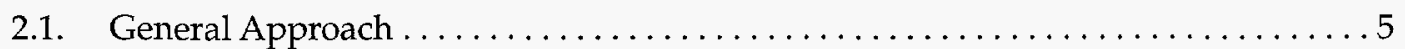

2.2. Model Development ............................... 8

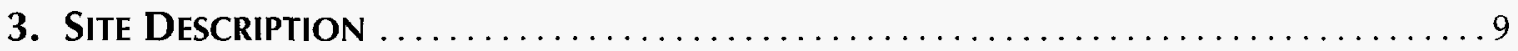

4. Development of the Three-Dimensional Grid $\ldots \ldots \ldots \ldots \ldots \ldots \ldots \ldots \ldots \ldots$

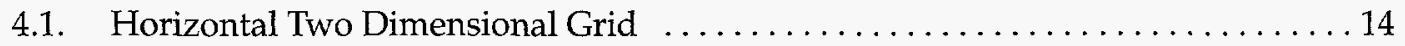

4.1.1. Location of boreholes . . . . . . . . . . . . . . . . . . . 15

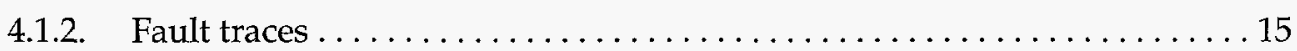

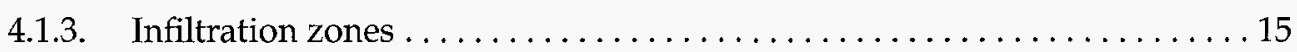




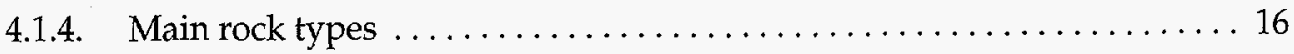

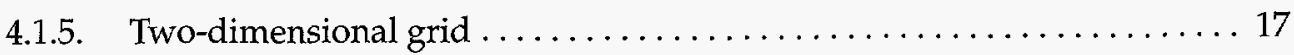

4.2. Design of Contour and Isopach Maps for Hydrogeologic Units $\ldots \ldots \ldots \ldots \ldots 17$

4.2.1. Data sources ..................................... 19

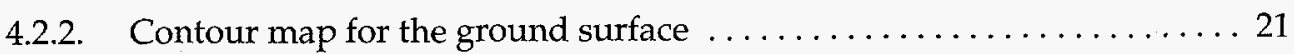

4.2.3. Contour map for the base of Tiva Canyon hydrogeologic unit . . . . . 21

4.2.4. Isopach map for the Paintbrush hydrogeologic unit $\ldots \ldots \ldots \ldots \ldots 21$

4.2.5. Isopach map for the Topopah Spring hydrogeologic unit $\ldots \ldots \ldots \ldots 22$

4.2.6. Contour map for the water table ...................... 23

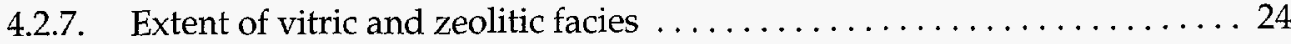

4.2.8. Isopach map for the Calico Hills hydrogeologic unit $\ldots \ldots \ldots \ldots \ldots 25$

4.3. Development of the Three-Dimensional Numerical Grid $\ldots \ldots \ldots \ldots \ldots \ldots 26$

4.3.1. Z-Coordinates of center node locations on unit boundaries . . . . . . 27

4.3.2. Subdivision of the hydrogeologic units $\ldots \ldots \ldots \ldots \ldots \ldots \ldots \ldots \ldots \ldots$

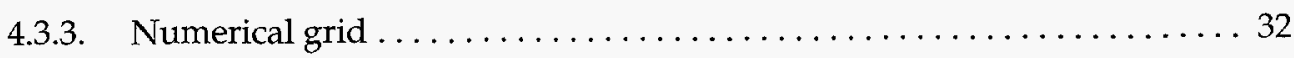

4.3.3.1. All gridblocks except those with offsets $\ldots \ldots \ldots \ldots \ldots . \ldots 33$

4.3.3.2. Gridblocks with offsets $\ldots \ldots \ldots \ldots \ldots \ldots \ldots \ldots \ldots \ldots \ldots \ldots \ldots \ldots$

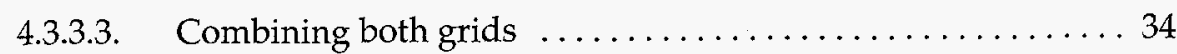

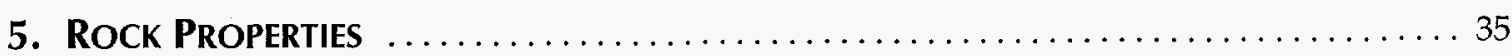

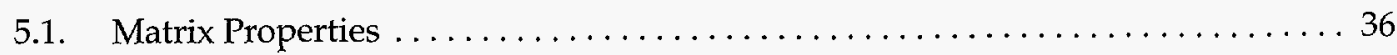

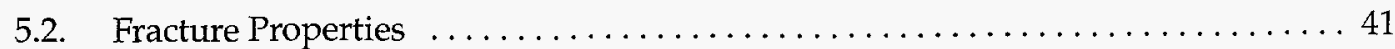

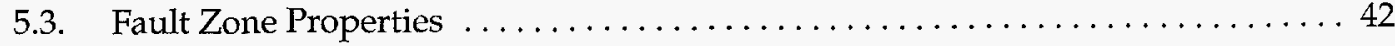

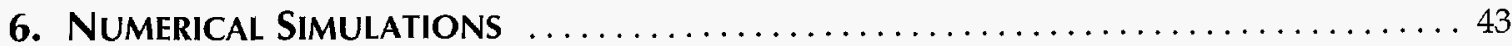

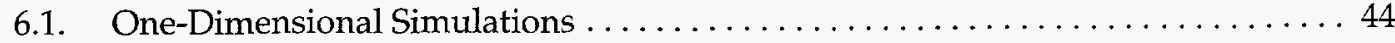

6.2. Two-Dimensional Simulations . ........................... 44

6.2.1. High permeability fault zone $\ldots \ldots \ldots \ldots \ldots \ldots \ldots \ldots \ldots \ldots \ldots 4$

6.2.2. Low permeability fault zone $\ldots \ldots \ldots \ldots \ldots \ldots \ldots \ldots \ldots \ldots \ldots$

6.2.3. Effect of two fault zones (simulations with cross-section B-B') $\ldots \ldots \ldots 50$

6.2.4. Vertical and lateral flow, perched water $\ldots \ldots \ldots \ldots \ldots \ldots \ldots \ldots$

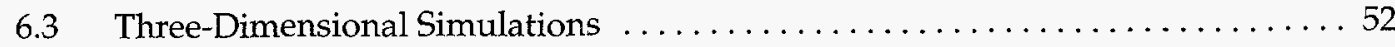

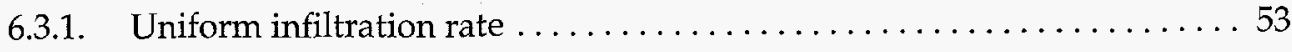

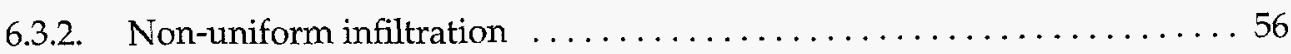


7. Model Predictions

8. Concluding Remarks

61

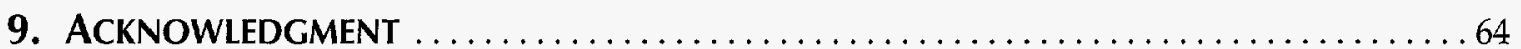

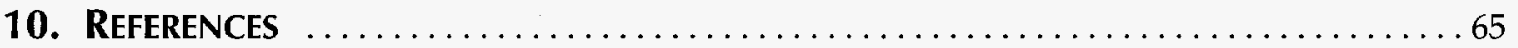

APPENDIX A

APPENDIX B 


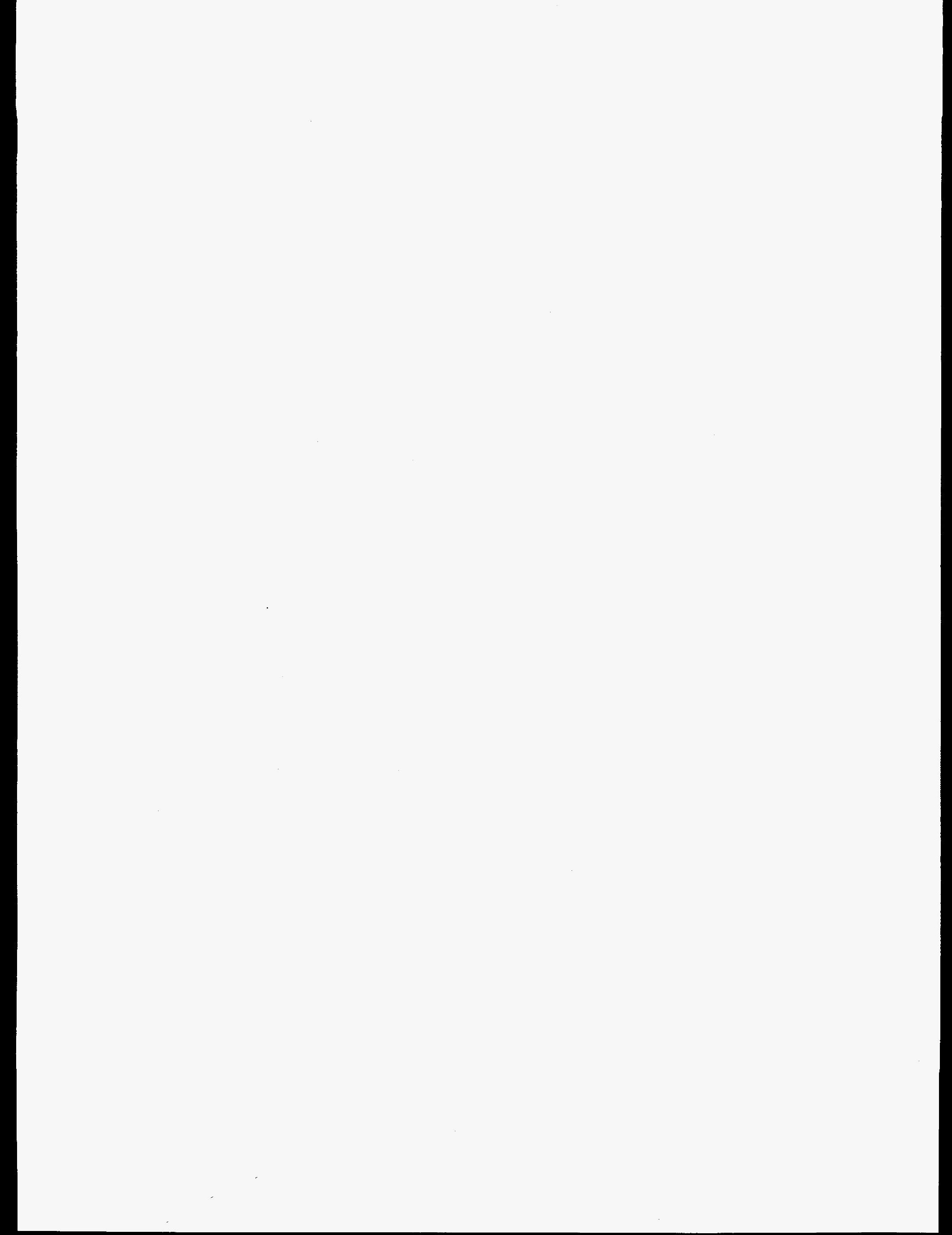




\section{List of Figures}

Figure 1. Simplified flow chart of the site-scale modeling approach. $\ldots \ldots \ldots \ldots \ldots \ldots 7$

Figure 2. Location of Yucca Mountain and the site-scale model area. Modified from Montazer and Wilson?

Figure 3. Close-up of the extent of the model area showing major and secondary faults, and the potential repository location.

Figure 4. NW-SE vertical cross section through the site-scale model area. Modified from Scott and Bonk $k^{9}$. Cross-section alignment is shown in Figure 3. . . 13

Figure 5. Approximate view of the different infiltration zones over the site-scale

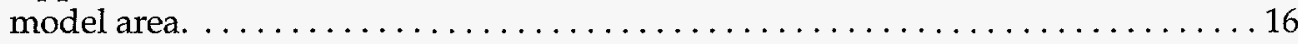

Figure 6. Schematic map of the different infiltration zones used for the site-scale model design. The distribution and topography of outcrops formed by the Tiva Canyon, Paintbrush and Topopah Spring hydrogeologic units is also given. . . . . . . . . . . . . . . . . . . . . . . . . 16

Figure 7. Horizontal grid for the site-scale model showing the location and identification number of the 286 gridblocks.

Figure 8. Contour map ( $\mathrm{m}$ above sea level) of the base of the Tiva Canyon hydrogeologic unit based on borehole lithology data.

Figure 9. Isopach map $(\mathrm{m})$ for Paintbrush hydrogeologic unit. $\ldots \ldots \ldots \ldots \ldots \ldots \ldots \ldots$

Figure 10. Isopach map $(\mathrm{m})$ for Topopah Spring hydrogeologic unit. . . . . . . . . . . 24

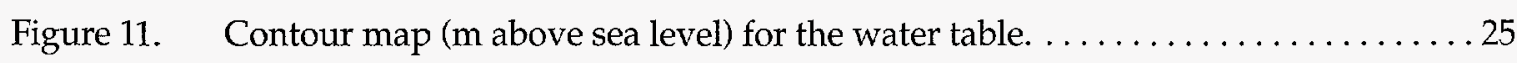

Figure 12. Isopach map $(\mathrm{m})$ for the unsaturated Calico Hills hydrogeologic unit. . . . . . 26

Figure 13. Distribution of layer thicknesses for the Tiva Canyon hydrogeologic unit gridblocks. 
Figure 14. Example of grid design near fault zones. . . . . . . . . . . . . . . . 34

Figure 15. Capillary pressure curves for the rock matrix of nonwelded tuffs

(Paintbrush and Calico Hills hydrogeologic units). The zeolitized

tuffs are represented by a dotted line. . . . . . . . . . . . . . . . . 41

Figure 16. Capillary pressure curves for the rock matrix of welded tuffs

(Tiva Canyon and Topopah Spring hydrogeologic units). The

Tiva Canyon tuffs are represented by a dotted line. ................. 41

Figure 17. Combined fracture and matrix capillary pressure curves for the

welded Tiva Canyon and Topopah Spring hydrogeologic units. . .

Figure 18. Capillary pressure curves for two types of fault zones. The low permeability fault is represented by a continuous line, and the high permeability fault by a dotted line.

Figure 19. Liquid-saturation profiles for a schematic vertical column of 19 and

46 gridblocks (infiltration rate $0.1 \mathrm{~mm} / \mathrm{yr}$ ) ..................... 45

Figure 20. Horizontal grid for the site-scale model showing the cross-sections used in the simulations $\left(\mathrm{A}-\mathrm{A}^{\prime}\right.$ and $\left.\mathrm{B}-\mathrm{B}^{\prime}\right)$ and for displaying 3-D simulation

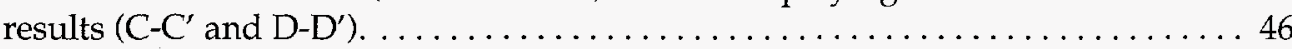

Figure 21. Schematic of vertical cross-sections (a) A-A'; and (b) B-B' showing fault offsets and model sublayer thickness variations.

Figure 22. Capillary pressure distribution for cross-section $A-A^{\prime}$ with infiltration rate of $10^{-1} \mathrm{~mm} / \mathrm{yr}$, and a saturated permeability of $10^{-11} \mathrm{~m}^{2}$ for Ghost Dance fault.

Figure 23. Liquid saturation distribution for cross-section A-A' with infiltration rate of $10^{-1} \mathrm{~mm} / \mathrm{yr}$, and a saturated permeability of $10^{-11} \mathrm{~m}^{2}$ for the Ghost Dance fault.

Figure 24. Capillary pressure distribution for cross-section B-B' with infiltration rate of $10^{-2} \mathrm{~mm} / \mathrm{yr}$, and a saturated permeability of $10^{-20} \mathrm{~m}^{2}$ for Abandoned Wash and Dune Wash faults.

Figure 25. Liquid saturation distribution for cross-section B-B' with infiltration rate of $10^{-2} \mathrm{~mm} / \mathrm{yr}$, and a saturated permeability of $10^{-20} \mathrm{~m}^{2}$ for the Abandoned

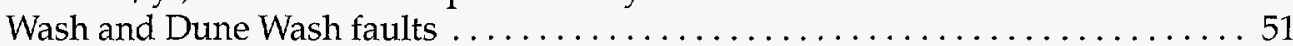

Figure 26. A quasi-three-dimensional calculated liquid saturation at Yucca Mountain shown using data for cross sections A-A', B-B', C-C' and D-D' (see Figure 20). . . 53

Figure 27. Calculated normalized vertical moisture fluxes (\% of infiltration at ground surface) at different depths in the site-scale model for the case of "capillary barrier" faults, and a uniform areal infiltration rate of

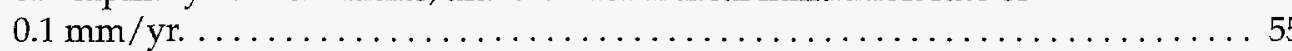

Figure 28. Calculated normalized vertical moisture fluxes (\% of infiltration at ground surface) at different hydrogeologic unit boundaries in the sitescale model for the case of "permeable" faults, and a uniform areal

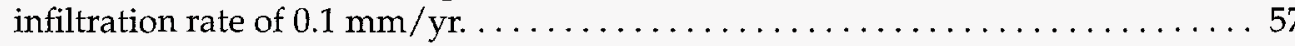


Figure 29. Calculated normalized vertical moisture fluxes (\% of average net infiltration) at different hydrogeologic unit boundaries in the site-scale model for the case of "capillary barrier" faults, and non-uniform infiltration (average $0.1 \mathrm{~mm} / \mathrm{yr}$ )

Figure 30. Borehole UE-25 UZ\#16 modeling predictions for saturation and capillary pressure versus elevation above mean sea level for a uniform infiltration rate of $0.1 \mathrm{~mm} / \mathrm{yr}$. 


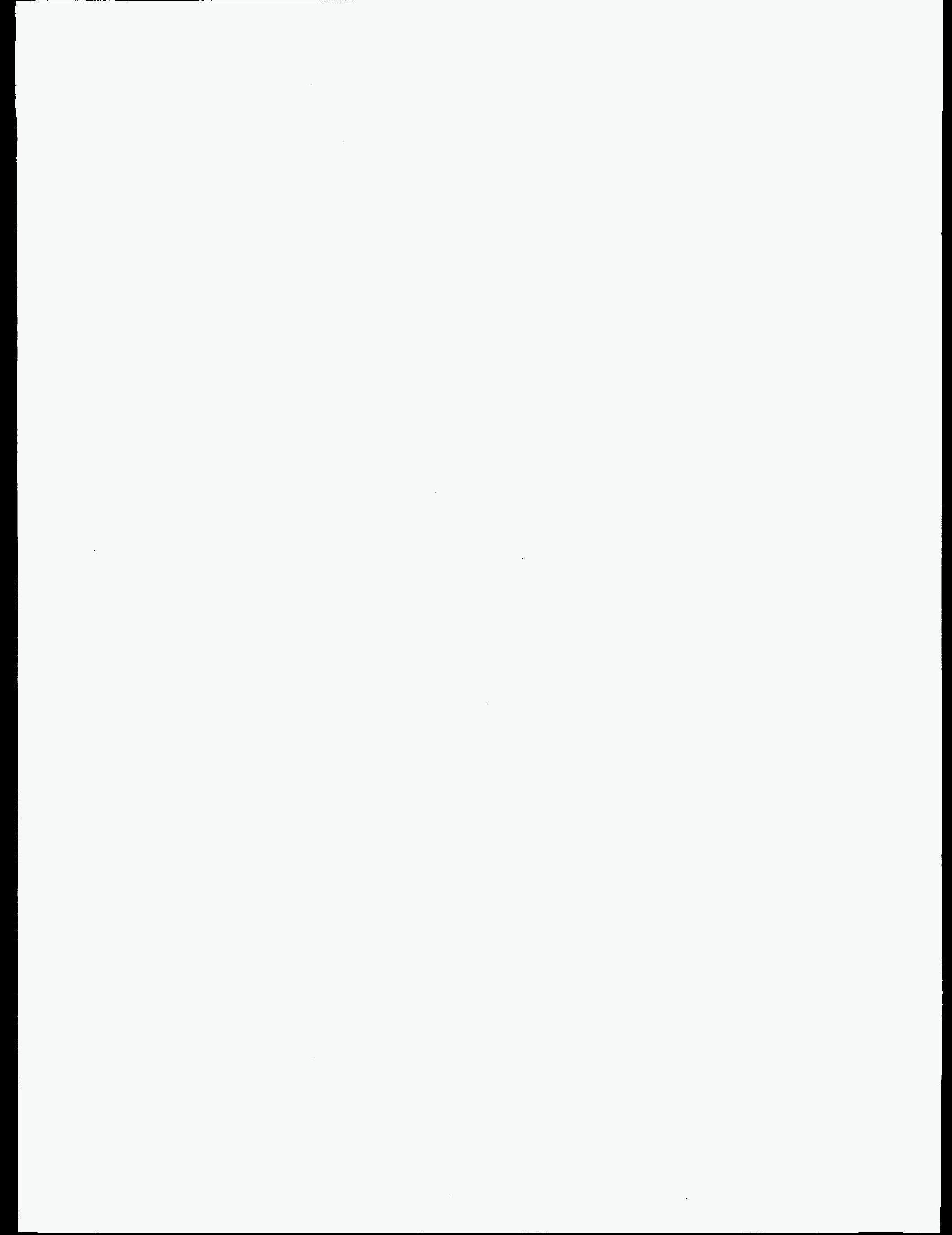




\section{List of Tables}

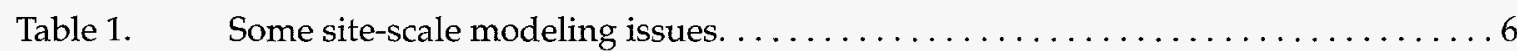

Table 2: $\quad$ Relation between major geologic members and Montazer and Wilson ${ }^{7}$

hydrogeologic units. . . . . . . . . . . . . . . . . . . . . . . . 12

Table 3. Previously published maps and cross-sections used for comparison during the three-dimensional grid design. . . . . . . . . . . . . . . . . 20

Table 4. Example of file with elevation of unit boundaries. ..................... 28

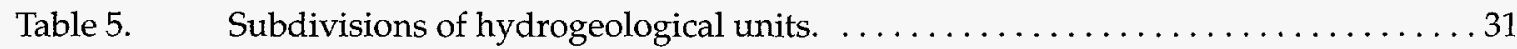

Table 6. Example of coordinate-file for the three-dimensional grid. . . . . . . . . . . 32

Table 7. Rock matrix properties for the seventeen model sublayers derived from the four hydrogeologic units. . . . . . . . . . . . . . . . . . . . 37

Table 8. Simplified dataset of rock matrix properties used for one-dimensional simulations. ..................................... 44 
A three-dimensional model of moisture flow within the unsaturated zone at Yucca Mountain is being developed at Lawrence Berkeley Laboratory (LBL) in cooperation with the U.S. Geological Survey (USGS). This sitescale model covers an area of about $34 \mathrm{~km}^{2}$ and is bounded by major faults to the north, east and west.

The model geometry is defined (1) to represent the variations of hydrogeological units between the ground surface and the water table; (2) to be able to reproduce the effect of abrupt changes in hydrogeological parameters at the boundaries between hydrogeological units; and (3) to include the influence of major faults.

A detailed numerical grid has been developed based on the locations of boreholes, different infiltration zones, hydrogeological units and their outcrops, major faults, and water level data. Contour maps and isopach maps are presented defining different types of infiltration zones, and the spatial distribution of Tiva Canyon, Paintbrush, and Topopah Spring hydrogeological units.

The grid geometry consists of seventeen non-uniform layers which represent the lithological variations within the four main welded and nonwelded hydrogeological units. Matrix flow is approximated using the van Genuchten model, and the equivalent continuum approximation is used to account for fracture flow in the welded units. The fault zones are explicitly modeled as porous medium using various assumptions regarding their permeabilities and characteristic curves. One-, two,-, and three-dimensional simulations are conducted using the TOUGH2 computer program. Steadystate simulations are performed with various uniform and non-uniform infiltration rates. The results are interpreted in terms of the effect of fault characteristics on the moisture flow distribution, and on the location and formation of preferential pathways. 


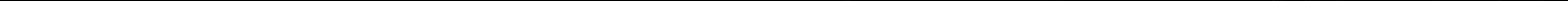




\section{INTRODUCTION}

\subsection{Cooperative Project}

The U.S. Geological Survey (USGS) is conducting site characterization studies of Yucca Mountain, Nevada, the potential site for underground storage of high-level radioactive waste. Lawrence Berkeley Laboratory (LBL) in cooperation with the USGS has developed a three-dimensional site-scale numerical model of the unsaturated zone at Yucca Mountain.

The work performed at USGS and LBL within the study plan "site unsaturated-zone modeling and synthesis" is subdivided into five activities, these are:

(1) Conceptualization of hydrogeologic system

(2) Development of codes

(3) Simulation of natural hydrogeologic system

(4) Uncertainty analysis

(5) Integration and synthesis

The present study reports work performed to date within tasks 1 and 3 , including the gathering of data, building a three-dimensional representation of the model area, and performing numerical one, two and three-dimensional simulations. These simulations are preliminary and will be superseded as the model development and refinement continues.

\subsection{Objectives}

The primary objectives of modeling the natural hydrogeologic system are:

(1) To investigate the feasibility of developing a detailed three-dimensional model of the moisture flow field at Yucca Mountain, attempting to incorporate the geologic complexities and the non-linearities involved with unsaturated fluid flow in fractured rocks.

(2) To use the model in the site characterization effort by evaluating temporal and spatial frequency of data needs.

(3) To quantify moisture flow within the unsaturated zone at Yucca Mountain and evaluate the effect of gas flow and the geothermal gradient on moisture flow.

(4) Calibration of model hydrologic parameters for use in Performance Assessment and radionuclide transport models. 
(5) Building confidence in long-term predictive models for which no direct comparisons with site data will be available.

Ultimately, the unsaturated-zone model will be combined with a similar model for the saturated zone to yield an integrated model to be used for repository performance predictions.

\subsection{Report Content}

Simulation of the natural hydrogeologic system at Yucca Mountain requires the collection and analysis of geological, geophysical, hydrogeologic, and geochemical data. All of these data are integrated into a three-dimensional numerical model referred to in this report as the "site-scale model."

The development of the site-scale model was performed in the following order:

- definition of model parameters, such as geological and tectonic framework, hydrogeologic units and model boundaries,

- building of the numerical grid,

- definition of hydrogeologic characteristics for the rock types, such as moisture retention and permeability curves,

- performance of one, two and three-dimensional numerical simulations (porous medium, continuum approach).

Following the introduction given in Chapter 1, which describes the general approach for the three-dimensional modeling at Yucca Mountain, a short description of the procedure followed during the development of the site-scale model is given in Chapter 2.

The description of the site, including stratigraphy and geologic structures, location of boreholes, model boundaries, and distribution of hydrogeologic units is presented in Chapter 3.

The development of the three-dimensional grid is given in Chapter 4 . Chapter 4.1 gives an overview of how the two-dimensional grid was built based on all surficial information, such as locations of main fault zones, and the distribution of infiltration zones. The design of contour and isopach maps for the various hydrogeologic units present in the unsaturated zone is described in Chapter 4.2. These maps are based on a large volume of information, and represent the first three-dimensional view of hydrogeologic units over the entire model area. In Chapter 4.3., the development of the three-dimensional grid for the site-scale model is described. The $\mathrm{x}$ and $\mathrm{y}$ coordinates for each center nodes of this grid are similar to those of the twodimensional grid, and the $z$ coordinates are determined based on the thickness of the hydrogeologic units, and on the offsets along major normal faults. 
The procedure used to define rock characteristic curves, such as moisture retention and permeability, is given in Chapter 5, as is the approach taken to include fracture flow in simulations.

Chapter 6 gives an overview of 1D-, 2D-, and 3D-simulations performed to check the grid geometry, and test the characteristic curves, and the moisture distribution that result from various assumed fault characteristics.

Chapter 7 provides a discussion of model predictions of observed phenomena at Yucca Mountain.

Concluding remarks and observations are presented in Chapter 8.

The main purpose of the current work described in the present report is to develop the numerical model in terms of the geological units, the major faults and offsets, the dipping, and other geological features affecting flow of moisture, gas, and heat at Yucca Mountain. Subsequent iterations of the report will focus on other important aspects of the model, including selection and justification of parameters pertaining to the hydrogeologic, thermal, and mechanical characteristics of the subsurface. Justification will include statistical analyses to support the data selection processes and evaluate the problem of scale in using data from laboratory measurements and applying it to large model gridblocks. Subsequent report iterations will also concentrate on thorough model sensitivity analyses to evaluate the uncertainties associated with boundary conditions, modeling assumptions, and material properties used in the model. The sensitivity analyses will also allow the determination of future data needs and priorities for the site characterization efforts. Future iterations will report on the results of calibration efforts comparing simulation results with measured data from the site characterization effort, including observed saturation, capillary pressure, temperature, and gas flow data. These items were not included in this report due to the limited approval of work scope during this phase of the modeling effort. However, some of these aspects of the modeling work are being performed during this fiscal year (FY95) and are intended to be included in the next iteration report.

\subsection{Previous Work}

The development of the site-scale model builds on previous modeling efforts, which began with the two-dimensional cross-section model developed by Rulon et al. ${ }^{1}$. Rulon et al. ${ }^{1}$ computed steady-state moisture distributions for different infiltration rates and flow conditions (fracture- and matrix-dominated flow), and identified the potential for lateral flow due to dipping of the stratigraphic units. Wang and Narasimhan, ${ }^{2}$ also using a twodimensional cross-section model, showed that the degree of lateral flow depends strongly on assumed hydrological parameters of vertical fault zones, 
especially the characteristic curves. Similar conclusions were reached by Osnes and Nieland ${ }^{3}$, and their results also indicated perched water near major faults, when the faults are modeled "as a highly permeable fractured zone". Recently, three-dimensional models of the "natural state" of the unsaturated zone at Yucca Mountain were developed by Rockhold et al. ${ }^{4}$ and Birdsell et al. ${ }^{5}$. Rockhold et al. ${ }^{4}$ studied the unsaturated zone in the immediate vicinity of the potential repository with their model extending $605 \mathrm{~m}$ in the N-S direction and $300 \mathrm{~m}$ in the E-W direction. They found considerable lateral flow due to the complex stratigraphy and perched water in some cases. The various cases they considered indicated mostly fracture-dominated flow in the shallow welded units (Tiva Canyon), but matrix dominated flow elsewhere. Birdsell et al. ${ }^{5}$ considered a larger model area $(4.5 \mathrm{~km}$ in N-S direction and $2.7 \mathrm{~km}$ in $\mathrm{E}-\mathrm{W}$ direction), but concentrated on radionuclide transport, including retardation. They reported strong effects of the stratigraphy on the flow field. Both three-dimensional models used a large number of gridblocks $(25,000$ to 30,000$)$, resulting in large computational efforts.

Fluid flow at Yucca Mountain has been previously studied using various assumptions about the hydrologic character of fault zones. These have been modeled as fractured medium ${ }^{1}$, seepage face $^{2}$, or altered single porosity and broken-up double porosity medium ${ }^{6}$. Through this work, important mechanisms and results concerning moisture flow in unsaturated fractured tuffs have been found. In the two-dimensional simulations conducted by Rulon et al. ${ }^{1}$, an increase in the average flux through Topopah Spring hydrogeologic unit, and a reduction of the lateral flow towards the fault zones occurred if the saturated permeability of the fault zone decreased from $5 \times 10^{-11} \mathrm{~m}^{2}$ to $5 \times 10^{-14} \mathrm{~m}^{2}$. Wang and Narasimhan ${ }^{2}$ studied the effect of a fault zone modeled as a seepage face (open boundary exposed to atmospheric pressure, no capillary force and infinite saturated permeability). They showed that even if the liquid saturation increases on the western side of the fault due to the tilting of the formations, no water enters the fault zone. They also emphasized that when both matrix and fracture flow are assumed, flow in the Topopah Spring unit occurs within the partially saturated rock matrix at steady-state conditions. Tsang et al. ${ }^{6}$ showed that if the fault zone is modeled as a high permeable single-porosity or double-porosity medium, and if the capillary suction of the zone has the same type of dependence between the saturated permeability and a capillary scaling parameter as the adjacent rocks, the fault zone has little effect in channeling or enhancing downward flow. The liquid saturation in the fault zone is lower than that in the neighboring rocks, but the overall saturation and capillary pressure distributions away from the fault zone are not influenced. Other work by Wang and Narasimhan ${ }^{8}$ suggested that the effect of infiltration pulses at the surface is dampened by the underlying tuff units. Their results showed that the welded tuff unit of the potential repository horizon exhibited only small changes 
in saturations, pressures, and potentials from steady-state values in response to the transient pulses.

\section{MODELING APPROACH}

\subsection{General Approach}

In the development of the site-scale model, one must consider and incorporate all the important complexities of the Yucca Mountain site as much as possible within the constraints of available knowledge and resources. Table 1 identifies some of the modeling issues related to simulating specific aspects of flow within a series of porous, fractured, and tilted rocks. The issues include the representation of complex geologic formations in the unsaturated zone at Yucca Mountain by a discrete grid with a limited number of layers. The necessary thermal, mechanical and hydrogeologic model parameters must be specified using a limited data set extrapolated across the model domain. Another problem is associated with the application of the results of laboratory measurements of hydrogeologic parameters to large gridblocks. Perhaps the most critical issue is the poorly known flow characteristics of the major faults which cross and surround most of the potential repository area. Previous studies have indicated that assumptions made regarding the conditions and the hydrological parameters of the faults greatly affect the results in terms of lateral flow and perched water. Although effects of the smaller fractures and matrix flow appear to be adequately described using composite characteristic curves 7,8 , the validity of this approximation will have to be studied in more detail before the model can be used with confidence. Additionally, studies estimating the amount of moisture flux in the subsurface on both an annual and long-term basis need to be performed to evaluate the infiltration variability and its effect on moisture flow. Thermal gradients and gas flow in the unsaturated zone also have to be studied to evaluate their effects on moisture flow patterns.

The general approach taken to better understand these issues and their effects on the simulation results is to initially develop a preliminary model for moisture flow only, neglecting gas flow and the geothermal gradient. The relatively coarse-grid model presently includes about 300 horizontal gridblocks and 17 layers to cover the different hydrogeologic units identified at Yucca Mountain. This degree of grid refinement was based on results from previous studies and on current data availability.

The site-scale model was designed to readily accommodate future refinements and complexities as additional data are collected, and as important features of the conceptual model are identified or changed. The main moisture-flow model has since been extended to include the effects of the 
Table 1. Some site-scale modeling issues.

- Uncertainties in flux determination

- Densely fractured welded units: Millions of fractures and matrix blocks

- Flow characteristics of major faults (e.g. Ghost Dance fault)

- Matrix versus Fracture flow and their representation

- Gas flow (Air + water vapor)

- Thermal effects on fluid flow

- Lateral flow and perched water

- Fracture and capillary barriers

- Using a discrete grid to represent geologic heterogeneities

- Mechanical, Thermal, and Hydrogeologic parameter determination

- Scale effects in applying laboratory values to large model gridblocks

prevailing geothermal temperature gradient and gas-flow and the results of the calibration procedure and sensitivity analyses will be discussed in future iterations of this report.

Figure 1 presents a flow chart of the site-scale modeling approach and its relation to the data-collection and the performance-prediction tasks. The site-scale model will eventually incorporate all available geological, geochemical and hydrological data in order to estimate moisture, gas and chemical transport within the unsaturated zone at Yucca Mountain. Extensive analyses will be performed on the data to statistically quantify their variability across the model domain. Data collection and analysis performed at USGS and by other scientists will feed directly into the conceptual model, and will also impact the choice of numerical codes and their development and modifications for the site-scale modeling effort. The results of the selection and development of numerical codes, and the refinement of the conceptual model performed within other tasks of the study plan, are very important ingredients of the evolving site-scale model. Various numerical submodels will be used later to investigate specific hypotheses and approximations, such as the influence of the grid resolution and orientation on the numerical results, the effect of spatial and temporal variation of infiltration, the effect of short- and long-term barometric variations, or the influence of the geothermal gradient on moisture- and gas-flows. The results from the submodels will be incorporated as needed into the main three-dimensional site-scale model to allow determination of processes that control the transport of moisture, chemicals and gas at Yucca Mountain. Additionally, studies 
will be made of the effect of the equivalent continuum approximation in representing fracture-matrix interaction. The assumptions concerning the flow characteristics of the faults in the model domain have been evaluated to some degree in this report. However, additional evaluations of the effects of fault characteristics will be performed by expanding the model grid so that faults near the present model boundaries can be assessed. Much of this work will be discussed in future iterations of this report.

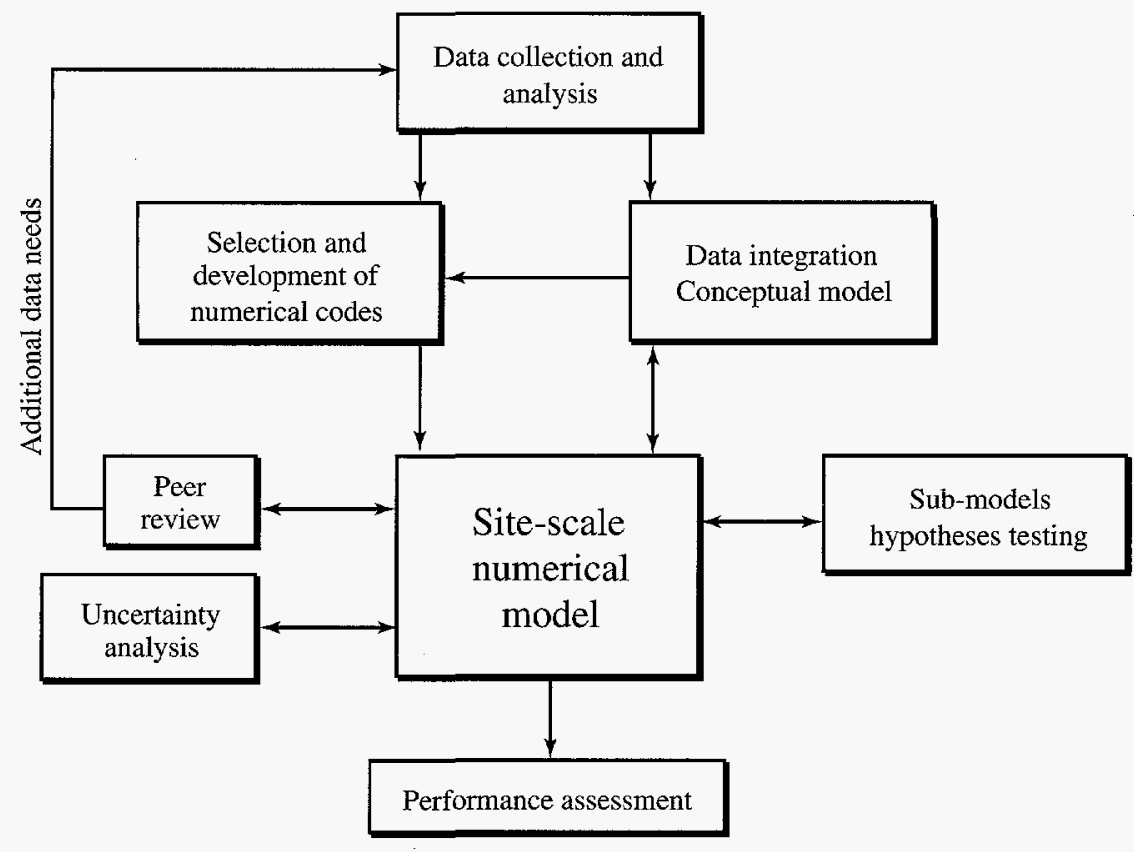

Figure 1. Simplified flow chart of the site-scale modeling approach.

The site-scale model will also help guide the site characterization effort at Yucca Mountain, especially in the type and amount of data needed. For example, sensitivity studies using the model may suggest that more detailed moisture-tension data are needed. Conversely, the simulations may show that a certain model parameter is of less importance, and, therefore, significantly reduce the number of field measurements needed for this parameter. The site-scale model will therefore provide a valuable tool to facilitate interactions between the collectors and the users of field data.

Peer review of the model results and the data collection process will be an essential part of the site-scale modeling effort. The peer review will occur at different levels, including model consistency and accuracy review, review of the input data to the model to ensure that it accurately considers field data and observations, review of additional data requirements, and review of technical validity of the approach and the overall model results. 


\subsection{Model Development}

The model development includes the creation of a numerical grid to represent the conceptual model of Yucca Mountain and extensive testing of the grid to establish how well it simulates moisture flow in the unsaturated zone. In order to address the hydrogeologic issues, and to facilitate the integration of all current information on the site, the model development has been performed through regular interaction with USGS scientists.

The numerical grid is designed to investigate hydrologic issues thought to be relevant to moisture flow at Yucca Mountain (see for example Scott and Bonk $^{9}$, and Montazer and Wilson ${ }^{7}$ ), including matrix versus fracture flow, fault effects, lateral flow, perched water, and capillary barriers. Consideration of these mechanisms, plus data analyses reported in Wittwer et al. ${ }^{10}$, led to the development of a highly non-uniform numerical grid that captures many aspects of the complex geology of this faulted and fractured region and explicitly includes the offset of the hydrogeologic units due to three major fault zones.

Two-dimensional, cross-sectional submodels extracted from the threedimensional numerical grid of the site-scale model were used to illustrate the complex geometry of the hydrogeologic units and their sublayers, and the variability in rock properties. Measurements of capillary pressure versus saturation recently performed ${ }^{11}$ on rock samples of Yucca Mountain were interpreted using methods developed by Brooks and Corey ${ }^{12}$, and van Genuchten ${ }^{13}$, to predict the relationships between relative permeability and capillary pressure for the unsaturated rocks. The equivalent continuum approximation described in Klavetter and Peters ${ }^{14}$ was used to couple fracture flow and matrix flow for welded tuffs. Fracture flow within the welded units was allowed for high liquid saturations, and fault zones were modeled as a porous medium with either very low or very high saturated permeability compared to adjacent rocks. The steady-state numerical simulations were carried out using the integral finite-difference computer code TOUGH2 (Transport of Unsaturated Groundwater and Heat) by Pruess ${ }^{15}$, and the moisture-flow distribution was calculated for various infiltration rates at the surface under the assumption that the fault zones behave as a porous medium with either high or low permeabilities. The results were interpreted in terms of the influence of major fault zones on the occurrence and intensity of vertical and lateral moisture flow, and on the existence of preferential pathways. All of these conditions may strongly affect the site suitability and the overall performance of the potential repository. This work is in progress as there are many studies planned using the three-dimensional site-scale model. 
Fluid flow at Yucca Mountain occurs through heterogeneous layers of anisotropic, fractured volcanic rocks in an arid environment. The location of Yucca Mountain and the extent of the model area are shown in Figure 2. The eastern, western and northern boundaries of the site-scale model were chosen in order to coincide with known or suspected structural features surrounding the potential repository area, or in the case of the southern boundary, to be located far enough to have no or little effect on moisture - or gas- flow in the repository area.

Nevada State Plane coordinates ${ }^{21}$ for the four apexes $(\mathrm{m})$ are given by:

$$
\begin{aligned}
& 238956.93 \mathrm{~N}, 170534.87 \mathrm{E}(\mathrm{N}-\mathrm{W} \text { corner }) \\
& 236568,45 \mathrm{~N}, 173798.45 \mathrm{E}(\mathrm{N}-\mathrm{E} \text { corner }) \\
& 228257.30 \mathrm{~N}, 172817.36 \mathrm{E}(\mathrm{S}-\mathrm{E} \text { corner }) \\
& 228272.56 \mathrm{~N}, 169265.29 \mathrm{E}(\mathrm{S}-\mathrm{W} \text { corner })
\end{aligned}
$$

The model covers an area of about $34 \mathrm{~km}^{2}$ centered around the potential repository area and is bounded by Bow Ridge fault to the east, and Solitario Canyon fault to the west. The model extends to the north as far as Yucca Wash, where the topography suggests that a major northwest trending fault may be present. The topography of the site-scale model area is dominated by a steep canyon (Solitario Canyon) to the west side of the model area. Numerous gullies cut the gently dipping east slope of Yucca Mountain, allowing the transport of erosion material to the alluvial flat located along the eastern side of the model area. Figure 3 shows the areal extent of the model, including the main faults at the boundaries, faults located within the site-scale model area and secondary smaller structural features. The various geologic structures were taken from maps and cross-sections published by Scott and Bonk ${ }^{9}$, and Nimick and Williams ${ }^{16}$. Reports by Tien et al. ${ }^{17}$ and Montazer and Wilson ${ }^{7}$ were used to obtain physical information about the faults. The major north to northeast striking faults are extensional features with steep westward dips. The vertical offset along these faults commonly ranges from ten to hundreds of meters and generally increases from north to south. For example, the vertical offset along Ghost Dance fault increases from a couple of meters at the northern end to $30 \mathrm{~m}$ at the southern end. The northwest trending faults in the northern part of the model area are interpreted as strike-slip features with horizontal displacement ranging from almost zero to a few tens of meters. All of these major features possibly penetrate the complete thickness of the unsaturated zone, and could control the moisture flow and the saturation distribution. The secondary faults within the boundary of the sitescale model are features with less than $10 \mathrm{~m}$ vertical offset ${ }^{7,17}$. 
At smaller scales, the occurrence of fractures is correlated with increases in the degree of welding of the volcanic rocks, which in turn influences the mechanical response of the rock to stress. The unsaturated zone consists primarily of Tertiary tuff having a south to southeast dip of about 5 to $30^{\circ}$. The tuffs range from porous, nonwelded ash-flows and bedded tuff deposits, to massive, highly brittle welded ash-flow rocks, depending on their deposition mechanisms and cooling history ${ }^{7,17}$. The zones comprising the geologic members were regrouped into informal hydrogeologic units based largely on the degree of welding following the conceptual model developed by Montazer and Wilson ${ }^{7}$. The hydrogeologic units consist of moderately to densely welded tuff zones alternating with zones of nonwelded to partially welded tuffs and bedded tuffs. The hydrogeologic units are referred to below as the Tiva Canyon, Paintbrush, Topopah Spring, and Calico Hills units. Table 2 summarizes the relation between the major geological members and hydrogeologic units and gives a brief description of the lithology. Due to

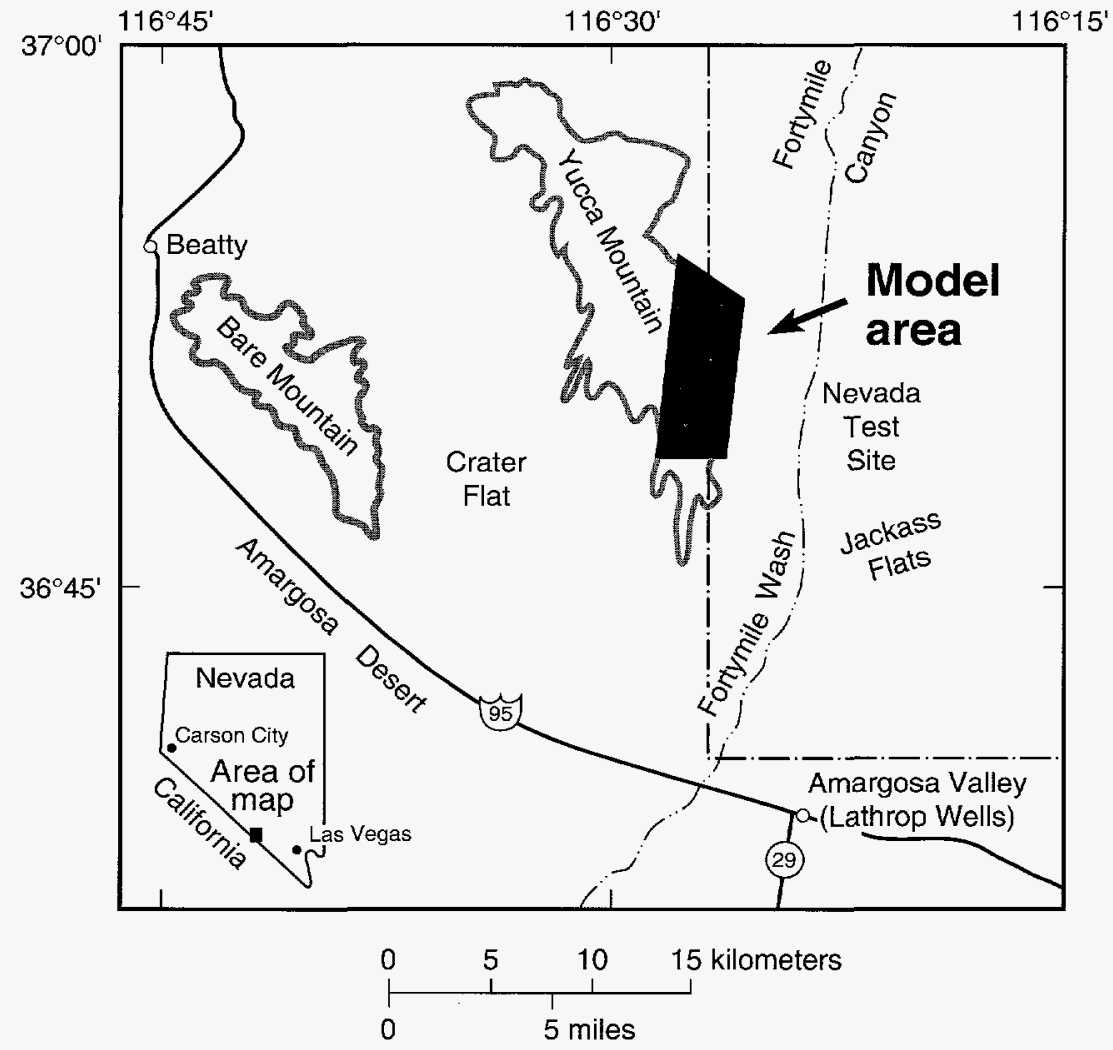

Figure 2. Location of Yucca Mountain and the site-scale model area. Modified from Montazer and Wilson?. 


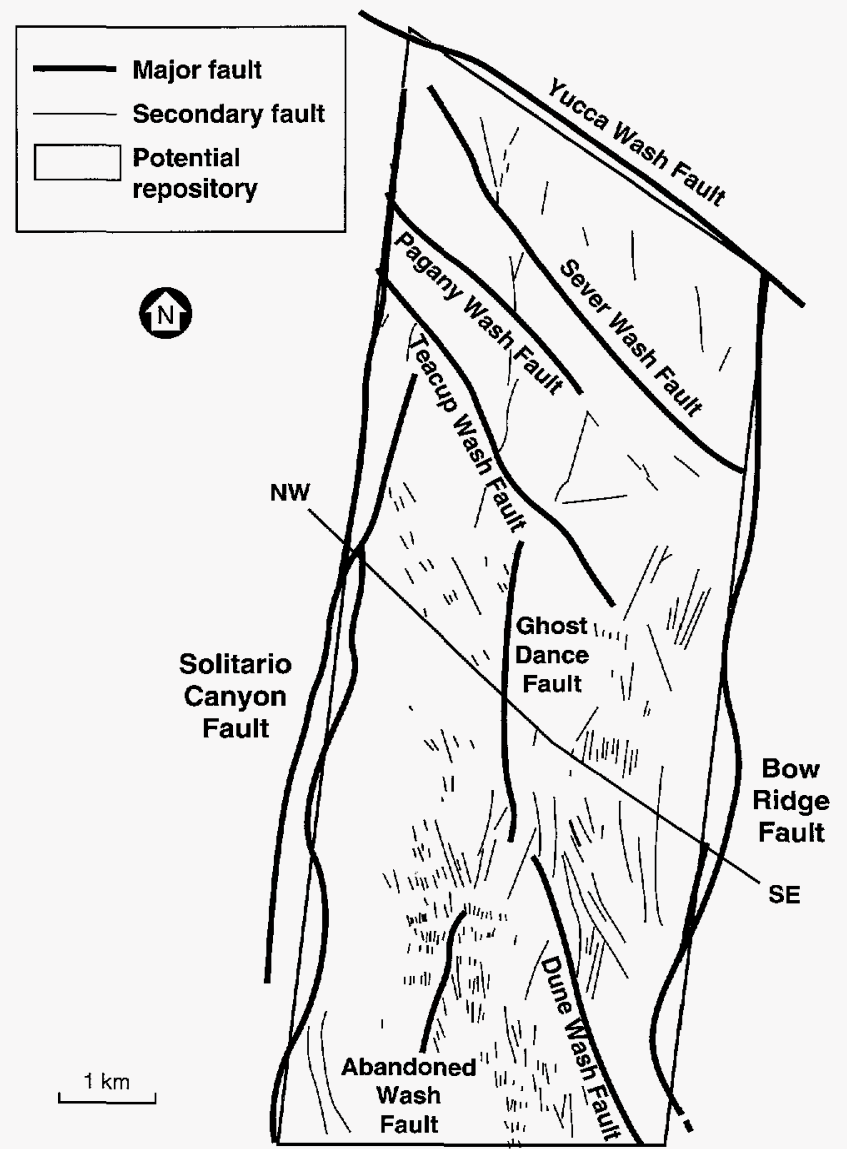

Figure 3. Close-up of the extent of the model area showing major and secondary faults, and the potential repository location.

cooling processes and ditterent response to tectonic events, the brittle welded and porous nonwelded tuffs have vastly different mechanical and hydrological properties. The welded zones of the Tiva Canyon and Topopah Spring Members are characterized by relatively low porosities (10 to $15 \%)^{7}$, low matrix permeabilities ( 2 to $\left.4 \times 10^{-18} \mathrm{~m}^{2}\right)^{7}$ and high fracture densities ( 8 to 40 fractures per cubic meter $)^{18}$. On the other hand, nonwelded and bedded tuffs, such as the Yucca Mountain and Pah Canyon Members, have higher matrix porosities $(25 \text { to } 50 \%)^{7,19}$ and permeabilities $\left(10^{-13} \text { to } 6 \times 10^{-15} \mathrm{~m}^{2}\right)^{7,19}$, and lower fractures densities (about 1 fracture per cubic meter) ${ }^{18}$. Zeolitic alteration appears in the lower part of the Topopah Spring Member, and in the Calico Hills hydrogeologic unit, and results in a decrease of the porosity and permeability of the tuffs. Thus, the Calico Hills unit has been divided into vitric and zeolitic zones. The fracture density is similar in both zones (2-3 
fractures per cubic meter) ${ }^{18}$, but the mean porosity of the vitric zone (range: 8 to $48 \%$ ) is slightly higher than that of the zeolitic zone (range: 15 to $35 \%)^{19}$. Similarly, the mean permeability of the vitric matrix is considerably higher $\left(10^{-13} \mathrm{~m}^{2}\right)$ than that of the zeolitic matrix $\left(10^{-16} \mathrm{~m}^{2}\right)$. Most of the surface of the site-scale model area consists of welded ash-flow tuffs of the Tiva Canyon Member. Along the western slope of Yucca Mountain Crest and in the northern part of the model area, the nonwelded and bedded tuffs of the Pah Canyon and Yucca Mountain Members, and the welded tuffs of the Topopah Spring Member are exposed.

Table 2. Relation between major geologic members and Montazer and Wilson ${ }^{7}$ hydrogeologic units.

\begin{tabular}{|c|c|c|c|}
\hline & $\begin{array}{l}\text { GEOLOGICAL } \\
\text { UNIT }\end{array}$ & LITHOLOGY & $\begin{array}{l}\text { HYDRO- } \\
\text { GEOLOGICAL } \\
\text { UNIT }\end{array}$ \\
\hline & $\begin{array}{l}\text { Tiva Canyon } \\
\text { Member }\end{array}$ & $\begin{array}{l}\text { densely welded tuff } \\
\text { moderately welded tuff }\end{array}$ & TIVA CANYON \\
\hline$\frac{0}{\partial}$ & & $\begin{array}{l}\text { partially welded tuff } \\
\text { nonwelded tuff } \\
\text { bedded tuff }\end{array}$ & \\
\hline $\begin{array}{l}\text { 心 } \\
\text { 品 }\end{array}$ & $\begin{array}{l}\text { Yucca Mountain } \\
\text { Member }\end{array}$ & $\begin{array}{l}\text { non- to moder. welded tuff } \\
\text { bedded tuff }\end{array}$ & PAINTBRUSH \\
\hline$\frac{\substack{\frac{c}{m} \\
\mathbf{m}}}{\underline{E}}$ & Pah Canyon Member & $\begin{array}{l}\text { non- to moder. welded tuff } \\
\text { bedded tuff }\end{array}$ & \\
\hline & Topopah Spring & non- to partially welded tuff & \\
\hline & & $\begin{array}{l}\text { moder. to densely welded tuff } \\
\text { densely welded tuff } \\
\text { basal vitrophyre }\end{array}$ & $\begin{array}{l}\text { TOPOPAH } \\
\text { SPRING }\end{array}$ \\
\hline & & moder. to partially welded tuff & \\
\hline & ICO HILLS FORMATION & non- to partially welded tuff & \\
\hline 品 & $\begin{array}{l}\text { Prow Pass } \\
\text { Member }\end{array}$ & $\begin{array}{l}\text { non- to partially welded tuff } \\
\text { bedded tuff }\end{array}$ & CALICO HILLS \\
\hline 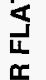 & Bullfrog Member & $\begin{array}{l}\text { non- to densely weided tuff } \\
\text { bedded tuff }\end{array}$ & \\
\hline 点 & Tram Member & non- moder. to welded tuff & \\
\hline
\end{tabular}

A NW to SE vertical cross-section through the middle of the model area aligned as shown in Figure 3 is presented in Figure 4. The cross-section shows the major normal fault zones along the western (Solitario Canyon fault) and eastern (Bow Ridge fault) model-area boundaries. The slightly 
east dipping hydrogeologic units are cut by a major fault (Ghost Dance fault) and many secondary faults. This cross-section illustrates the complexity of the geological and hydrogeologic features, all of which need to be considered in some fashion in the site-scale model.

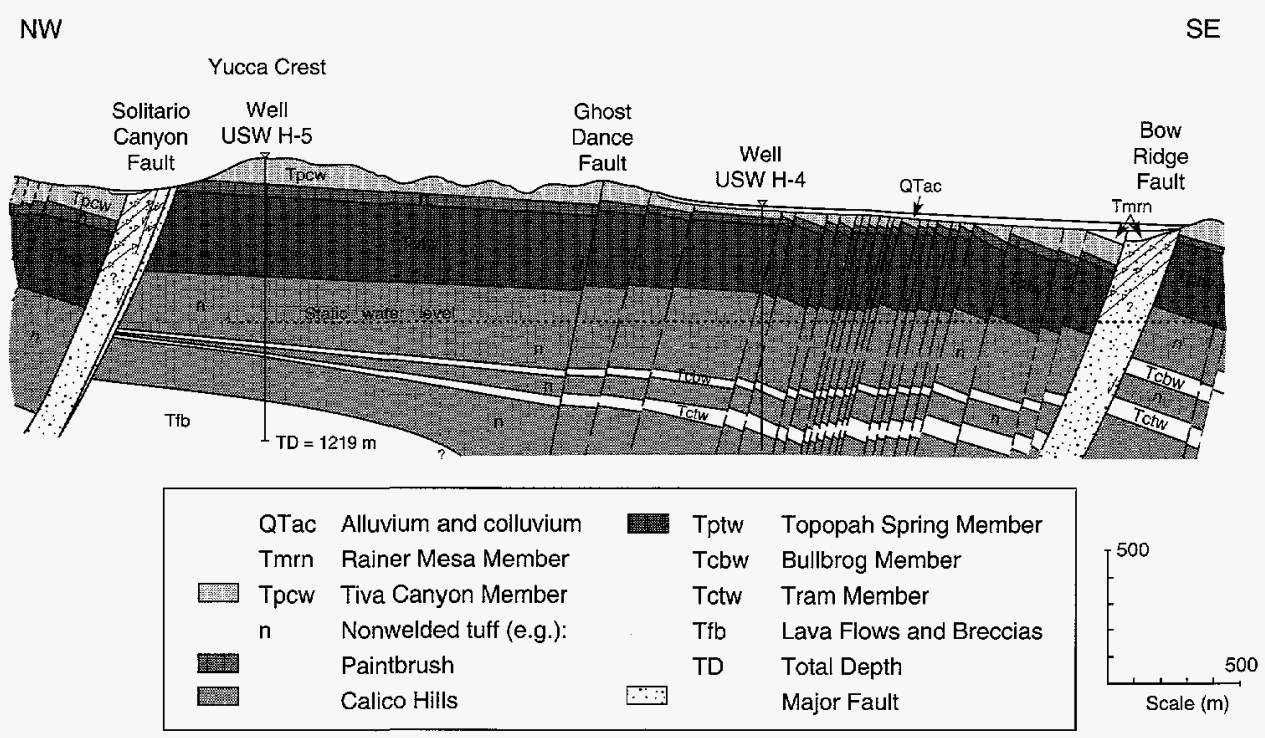

Figure 4. NW-SE vertical cross section through the site-scale model area. Modified from Scott and Bonk ${ }^{9}$. Cross-section alignment is shown in Figure 3.

\section{DEVELOPMENT OF THE THREE-DIMENSIONAL GRID}

The lithological section between the ground surface and the water table in the site-scale model is represented by a series of massive and fractured welded parts of ash-flow tuffs (Tiva Canyon and Topopah Spring Members), and porous nonwelded parts of ash-flow and ash-fall tuffs (Yucca Mountain and Pah Canyon Members, Calico Hills Formation, and Prow Pass Member, etc.). As discussed earlier, these rocks have been characterized as hydrogeologic units with different flow properties. The spatial distribution of these units was defined in Wittwer et al. ${ }^{10}$ by using available information on lithological logs from wells and surface data. This information was used to develop the numerical grid of the three-dimensional site-scale model.

The computer code used in the present study is based on the integrated finite-difference method, and allows the creation of irregular gridblocks. The grid was designed in order to consider the spatial distribution of main hy- 
drogeologic units, the effects of major structural features, the potentially sharp hydraulic gradients at the boundaries between hydrogeologic units, and relevant surficial information.

The three-dimensional numerical grid, consisting of about 5000 elements and 20,000 connections, was designed in two steps. First, available surficial information was used to create a horizontal, two-dimensional grid. Then, data from isopach maps of the hydrogeologic units were used to develop the grid between the ground-surface and the water table.

\subsection{Horizontal Two-Dimensional Grid}

The locations of the nodal points for the horizontal two-dimensional grid were based on the following criteria:

(1) Coincidence with the locations of existing or proposed boreholes. This allows direct comparison of model results with actual field data.

(2) Alignment along known major faults, such as the Ghost Dance fault, Dune Wash fault and Abandoned Wash fault. This alignment allows one to explicitly prescribe "fault properties" to the gridblocks represented by the faults. When sufficient data are collected, this will allow subsequent incorporation of a subgrid of fine gridblocks to represent more accurately the small thickness (perhaps $1 \mathrm{~m}$ or less) of the fault zones themselves. For the gridblocks representing the fault zones, the effect of varying offsets (10 to more than a hundred meters) can be schematically included in the grid design.

(3) Areally distributed to properly reflect the different infiltration zones that have been hypothesized on the basis of topography and surficial rock types.

(4) Areally distributed to properly reflect the areas where different rock types are exposed.

(5) Gradual changes in element sizes to minimize errors in representing gradients in thermodynamic variable conditions, hence minimizing model inaccuracies.

The grid was therefore constructed by placing the center nodes for about 300 gridblocks at the location of existing boreholes, along the traces of major fault zones, or by distributing them in order to consider the different infiltration zones, and the spatial distributions of various types of outcrops, such as welded and nonwelded tuffs. 


\subsubsection{Location of boreholes}

As often as possible, the locations of existing and proposed boreholes were used as center nodes. Maps prepared by Scott and Bonk ${ }^{9}$, and data from the Management and Operating Contractor $(\mathrm{M} \& \mathrm{O})^{20}$ allowed tabulation of borehole locations. Nevada State Plane coordinates $(\mathrm{m})$ and gridblock identifiers for the boreholes are given in Table A in Appendix B. When some of these locations were too close, one of them was chosen as center node in order to create a grid with regular sizes of gridblocks. Outside of the model area, the locations of 14 additional boreholes were used as control points to build isopach maps of the hydrogeologic units (see Chapter 4.2.).

\subsubsection{Fault traces}

Within the model area, only major structural features were considered for the grid design. These included the three major north-south normal faults (Ghost Dance, Abandoned Wash and Dune Wash), and the three northwest-southeast strike-slip faults in the northern part of the model. Gridblocks were aligned along the traces of these structures which are believed to be relevant features for moisture- and gas-flow at Yucca Mountain ${ }^{1,2,6,7}$. On the other hand, the smaller faults and fractures have only been implicitly considered in the numerical simulations. As the mean width of the approximately rectangularly-shaped gridblocks varies from 100 to 300 $\mathrm{m}$., the faults are modeled as zones with distinct hydraulic properties, and not as planar surfaces.

\subsubsection{Infiltration zones}

At Yucca Mountain, infiltration is believed to be extremely variable spatially. Because of variations in soil cover, different mechanisms control the net infiltration from rainfall. Based on studies of evapotranspiration rates, retention time, effect of slope and fracture exposure, weighting factors for surfaces of 150 by 150 feet will be determined to calculate the net infiltration. These values will be integrated to obtain infiltration rates over each of the model gridblocks. The model area has therefore been divided into three types of infiltration zones, such as alluvium (26\%), sideslopes $(60 \%)$ and ridgetops (14\%). Figure 5 shows the areal distribution of the different infiltration zones based on the geologic map by Scott and Bonk $k^{9}$ and topographic maps $^{31}$ of the site.

As the shape of those zones is extremely irregular, especially for alluvium located in the small washes, a schematic map was designed, which retained the main features of the detailed infiltration zones but also remained consistent with the mean size of the gridblocks. This simplified map of infiltration zones, shown in Figure 6, was used as basis for the design of the twodimensional grid. 


\subsubsection{Main rock types}

The spatial distribution of the various types of rocks which crop out at the surface of the site-scale model area was also taken into account in the grid design because it was assumed that their different hydrogeologic flow properties, controlled by the degree of welding and fracturing, would possibly affect the net infiltration rates. Figure 6 shows the distribution of the welded tuffs comprising the Tiva Canyon hydrogeologic unit exposed along most of the surface of the model, along with the distribution of alluvium and Paintbrush- and Topopah Spring hydrogeologic unit outcrops. The gridblocks of the horizontal grid are aligned to schematically reflect the distribution of these different welded and nonwelded rocks.

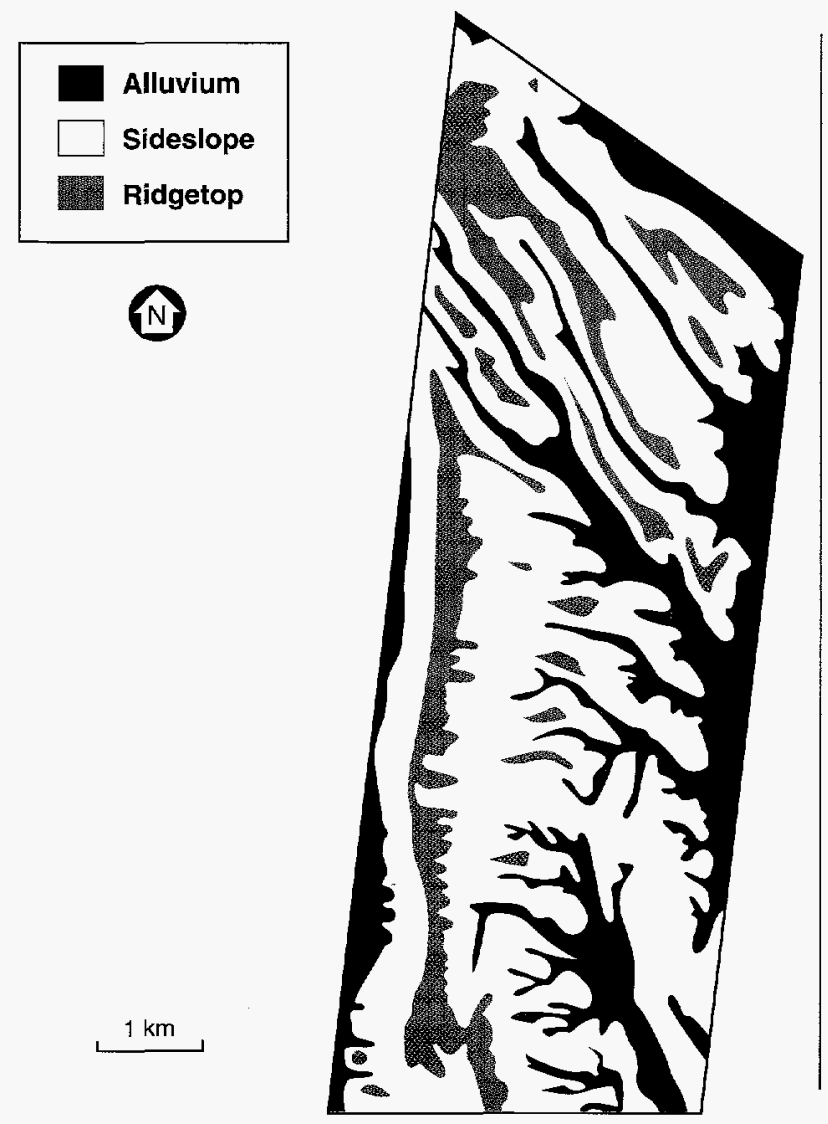

Figure 5. Approximate view of the different infiltration zones over the site-scale model area.

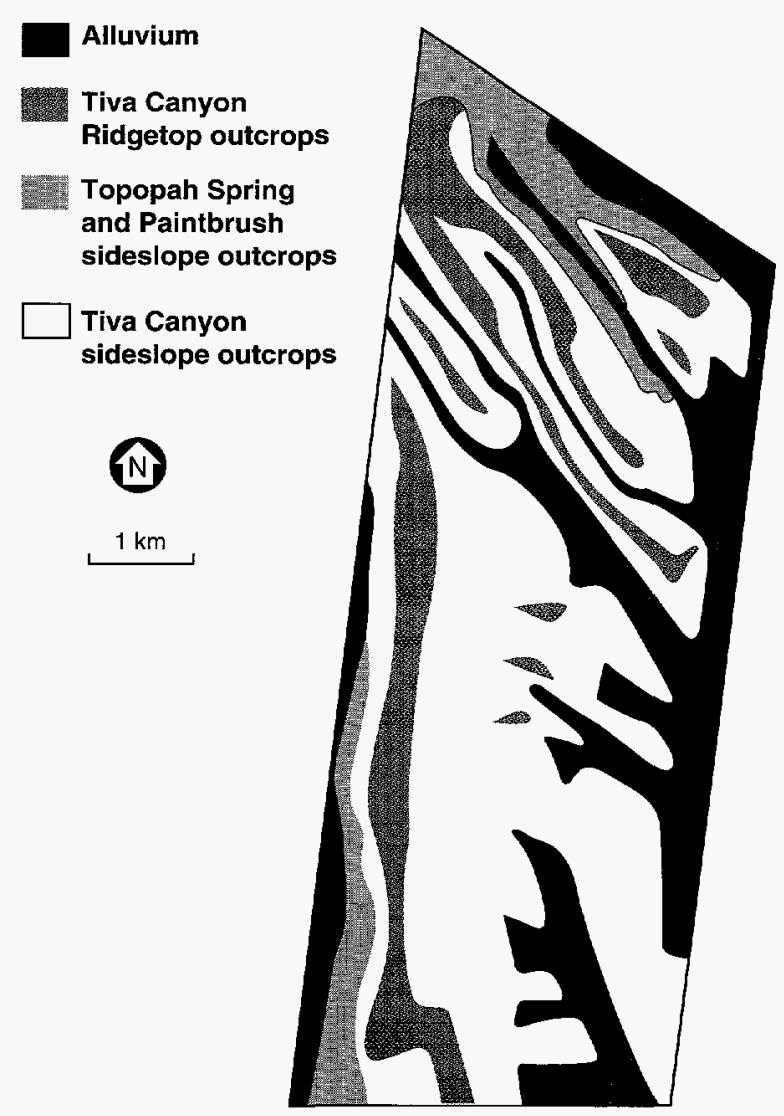

Figure 6. Schematic map of the different infiltration zones used for the site-scale model design. The distribution and topography of outcrops formed by the Tiva Canyon, Paintbrush and Topopah Spring hydrogeologic units is also given. 


\subsubsection{Two-dimensional grid}

The nodal points were located based on the above criteria over the entire model area. Their relative coordinates were obtained by using a digitizing table. Their Nevada State Plane coordinates were calculated by a program which uses the absolute Nevada State Plane coordinates for a subset of points and the relative coordinate information.

After all the nodal points had been located, a numerical grid generator was used to develop the horizontal grid. The grid for the site-scale model is shown in Figure 7, and illustrates how the shapes of the gridblocks were created by the mesh generator. One of the options of this mesh generator uses the medians between a chosen center node and the closest surrounding nodes to build the surface of each gridblock. The program needs the coordinates of the center nodes and the bounds of the working area. It creates two files. The first one (the connection-file) includes the connection length between each couple of center nodes, the length or surface area of their interface, depending on the dimensionality of the grid, and the angle of the connection with a horizontal plane. The second one (the element-file) includes the surface area or volume of each gridblock. The location of some of the center nodes had to be moved slightly to improve block shapes, or better align blocks along the fault traces. This final grid is composed of 286 gridblocks. The Nevada State Plane coordinates of their center nodes are given in Table B of Appendix B.

\subsection{Design of Contour and Isopach Maps for Hydrogeologic Units}

The vertical grid was designed based on the spatial distribution of the main hydrogeologic units, which includes the two welded units, (Tiva Canyon and Topopah Spring), and the two nonwelded units (Paintbrush and Calico Hills). A geometrical three-dimensional representation of these units was developed to obtain the elevations of the unit boundaries over the entire model area. This was done by compiling all available geological data from maps and borehole reports to create contour and isopach maps for each of these hydrogeologic units. Surficial data, such as fault offsets, dips and strikes of the beds taken from the geological map by Scott and Bonk ${ }^{9}$, as well as lithologic logs of the boreholes, were laterally and vertically extrapolated to obtain a three-dimensional picture down to the water table. Of the numerous fault traces reported on the geological map by Scott and Bonk ${ }^{9}$, only the Ghost Dance-, Abandoned Wash-, and Dune Wash faults were simulated in an explicit manner by accounting for their offsets in the design of the vertical grid. Because their offsets generally increase from north to south up to more than a hundred meters, and these normal faults play a potentially important role on moisture- and gas-flow, these structural features were therefore in- 


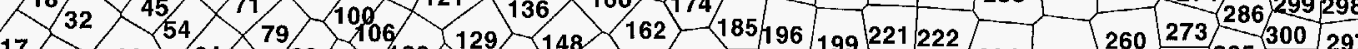

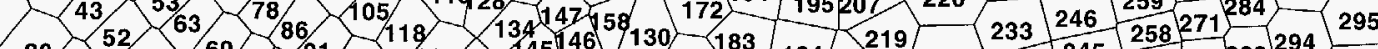

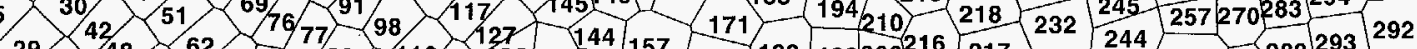

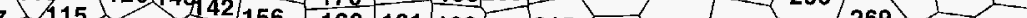

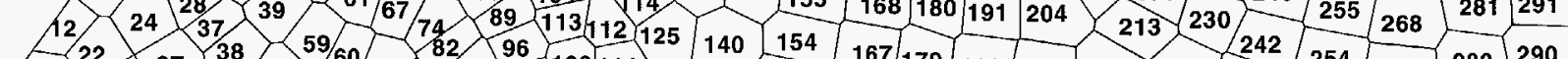

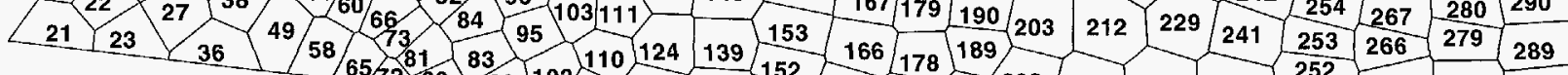

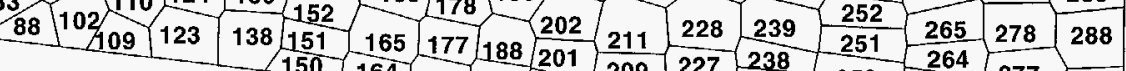

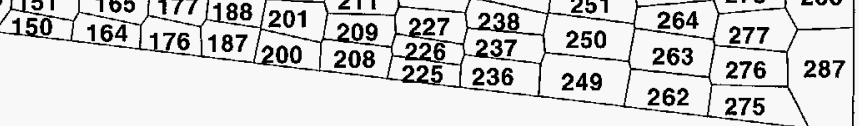


cluded in the design of the contour maps. On the other hand, it was decided that regions with many normal faults of smaller displacement or strike-slip faults, such as the Teacup Wash and Pagany Wash faults, would be modelled in an implicit manner by modification of the characteristic curves for the relevant gridblocks. Their offsets were therefore not considered for the grid design, and these features were only considered in the design of the twodimensional grid by keeping gridblocks aligned along their traces.

\subsubsection{Data sources}

Various data sources were used to obtain elevations above sea level for boreholes inside and close to the site-scale model boundaries. A complete list of these USGS and Sandia National Laboratories reports, and other information sources is given in Table $C$ of Appendix B.

The lithologic log descriptions were used to locate the boundaries between hydrogeologic units as defined according to the conceptual model in Montazer and Wilson ${ }^{7}$. These include:

- the moderate to densely welded zones of the Tiva Canyon geologic member, called the Tiva Canyon hydrogeologic unit. The thickness of any alluvium overlying the Tiva Canyon unit was not explicitly included in the thickness of the grid, but indirectly accounted for by defining infiltration zones.

- the lower partially to nonwelded zones of the Tiva Canyon geologic member, partially to nonwelded Yucca Mountain and Pah Canyon Members, the porous interlayers of bedded tuffs, and the upper partially to nonwelded part of the Topopah Spring Member, referred to as the Paintbrush hydrogeologic unit.

- the welded zones of the Topopah Spring Member, called the Topopah Spring hydrogeologic unit.

- the moderately to nonwelded zones of the Topopah Spring Member underlying the basal vitrophyre, the partially to nonwelded tuffs of the Calico Hills formation, and other partially to nonwelded tuffs located below Calico Hills formation (Prow Pass, Bullfrog, and Tram Members of the Crater Flat Unit) referred to as the Calico Hills hydrogeologic unit.

The correlation between hydrogeologic and stratigraphic units was given above in Table 2. A complete list with elevations above sea level of those hydrogeologic units boundaries and their unit thicknesses, together with data on water table elevation and total depth is given in Table D of Appendix $\mathrm{B}$ for the 34 boreholes used in the design of the three-dimensional grid.The 
boundary between zeolitic and vitric facies was also recorded from the lithologic logs and is presented in Table D.

The contour and isopach maps developed from the borelog information were compared to previously published cross-sections and maps by $\mathrm{Carr}^{27}$, Robison ${ }^{28}$, Nimick et al. ${ }^{16}$, Tien et al. ${ }^{17}$, and Ortiz et al. ${ }^{29}$. A list of these authors with reports and reference numbers is given in Table 3 , and shows which types of comparison could be done between the data compiled by these authors and the maps described here.

The contour and isopach maps were compared to large-scale regional maps developed for the same or similar hydrogeologic units. The discrepancies between the two sets of maps were resolved on the basis of the lithological logs and surface data when available. The contour and isopach maps presented here were adapted to fit the regional features depending on the extent of each hydrogeologic unit.

Table 3. Previously published maps and cross-sections used for comparison during the three-dimensional grid design.

SCOTT and BONK, 1984 (USGS OFR 84-494)

geologic map

CARR, 1984 (geologic map with major faults) (USGS OFR 84-854) base of Tiva Canyon Member map

ROBISON, 1984 (USGS WRIR 84-419) water-table map

NIMICK et al., 1984 (geological units, northern limit USW G2) (Sand 83-2593) cross-sections

TIEN et al., 1985 (geological units, northern limit USW G2) (Sand 84-2668) Tiva Canyon Member isopach map Yucca Mountain Member isopach map Pah Canyon Member isopach map Topopah Spring Member isopach map bedded tuff of Calico Hills isopach map

ORTIZ et al., 1985 (hydrogeologic units, northern limit USW G2) (Sand 841076) water-table map thickness between basal vitrophyre of the Topopah Spring and zone of prevalent zeolites map lower lithophysal zone of the Topopah Spring isopach map basal vitrophyre of the Topopah Spring isopach map cross-sections 


\subsubsection{Contour map for the ground surface}

As the upper model boundary is located at the ground surface, the map of Yucca Mountain published by EG\&G Energy Measurements, Inc. $(E G \& G)^{31}$ was chosen to obtain the maximum elevation of the grid. This map was not corrected for the thickness of the alluvium, which is not explicitly considered in the model as a hydrogeologic unit, based on the assumption that alluvium thickness is small relative to the thickness of the unsaturated zone as a whole and can therefore be ignored.

\subsubsection{Contour map for the base of Tiva Canyon hydrogeologic unit}

Different types of data were taken into account to design the contour map for the base of the welded Tiva Canyon hydrogeologic unit given in Figure 8. It was developed by taking into account the offsets along the three major normal faults. These offsets were determined from the geological maps and cross-sections published by Scott and Bonk, ${ }^{9}$ and Nimick and Williams. ${ }^{16}$ The hydrogeologic unit boundary elevations, based on lithologic data from available boreholes, were combined with data on dips and strikes taken from the geological map to obtain consistency between surficial data and subsurface data. The outcrop elevations of the boundaries of the unit were determined from the geological map ${ }^{9}$ and were also included to obtain more data points in the northern and western part of the model area. The spacing of the contour lines was checked in order to agree with the dip of the geologic zones recorded at the surface. The contour map of the base of the Tiva Canyon hydrogeologic unit shown in Figure 8 agrees reasonably well with a map of geologic boundaries previously published by Carr ${ }^{27}$, with less borehole data but a greater number of faults. The contour map does not show where erosive processes have locally removed part or all of the Tiva Canyon unit, such as in the Yucca Wash or Solitario Canyon area. This was accounted for in the process of discretizing the contour map for input into the model grid by comparing the predicted elevation of the unit bottom with the ground surface elevation provided by $E G \& G^{31}$ and omitting any nodes removed by erosion.

\subsubsection{Isopach map for the Paintbrush hydrogeologic unit}

Because some of the boreholes are rather shallow, there was insufficient information within the model area to estimate the offsets of this deeper unit along the faults. An isopach map was therefore developed for the Paintbrush nonwelded hydrogeologic unit which shows the thickness prior to faulting. The upper boundary for the unit was set between the moderately to densely welded zones and the lower partially to nonwelded zones of the Tiva Canyon Member. The lower boundary was set between the upper partially to 
Figure 8. Contour map ( $\mathrm{m}$ above sea level) of the base of the Tiva Canyon hydrogeologic unit based on borehole lithology data.

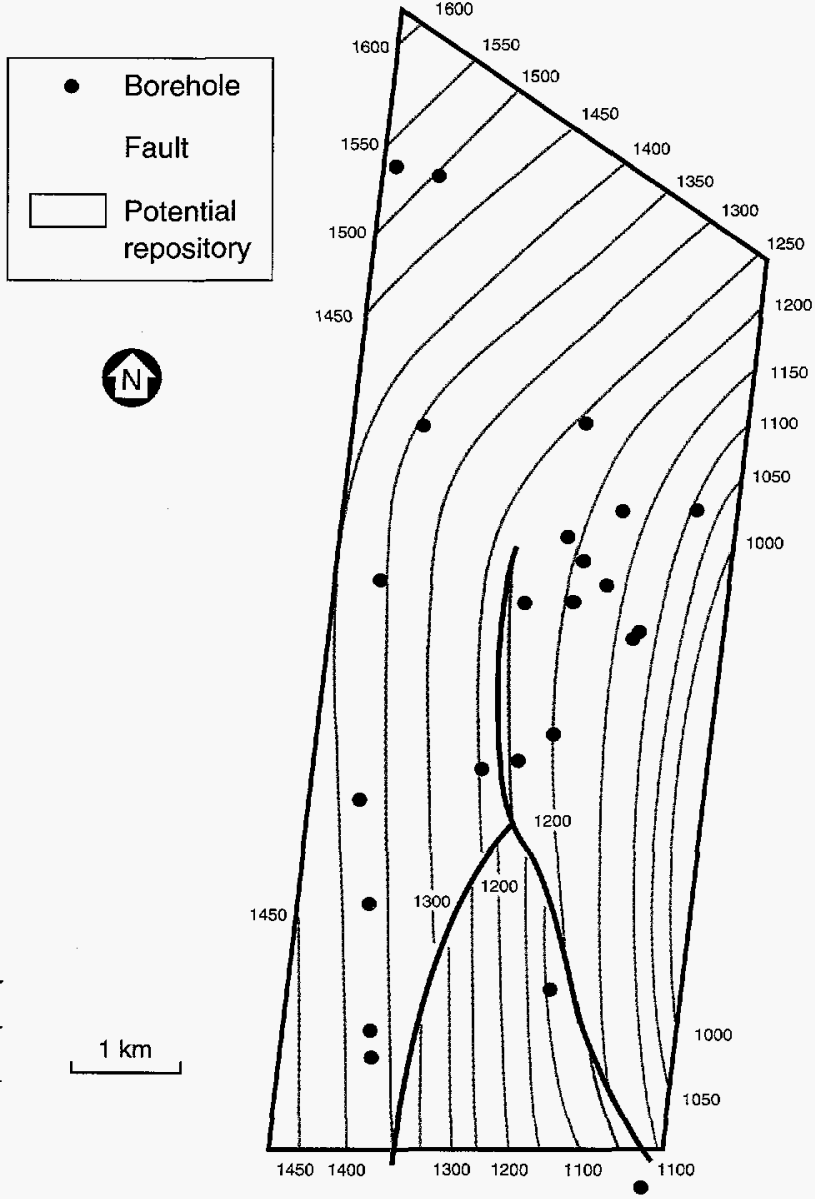

nonwelded part of the Topopah Spring unit and its more densely welded zones. Lithologic logs from twenty nine boreholes located inside and around the border of the model area were used to develop the isopach map of the Paintbrush hydrogeologic unit given in Figure 9. Because of the lack of data in the Northern part of the model area, the thickness of the unit was estimated from the geological map by Scott and Bonk ${ }^{9}$. Isopach maps (based on thicknesses of the geological units) have been published for the Yucca Mountain and the Pah Canyon Members by Tien et al. ${ }^{17}$. These maps were used only as guidelines for the main deposition features of the tuffs because they do not consider the hydrogeologic division of the volcanic sequence.

\subsubsection{Isopach map for the Topopah Spring hydrogeologic unit}

The isopach map for the Topopah Spring hydrogeologic unit was based on data from twenty three boreholes shown in Figure 10. An isopach map for 
Figure 9. Isopach map (m) for Paintbrush hydrogeologic unit.
- Borehole

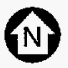

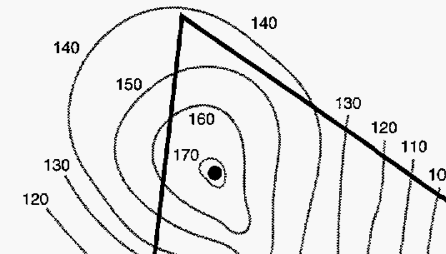

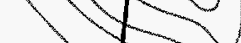

$$
\begin{array}{r}
110 \\
100 \\
90 \\
\hline
\end{array}
$$

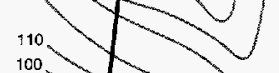

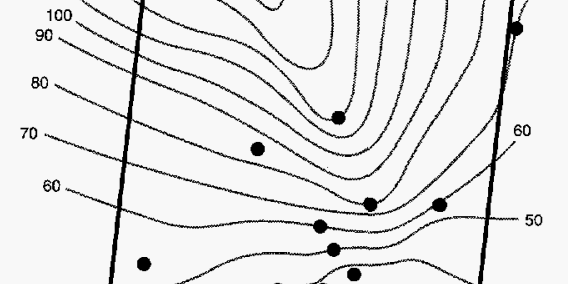
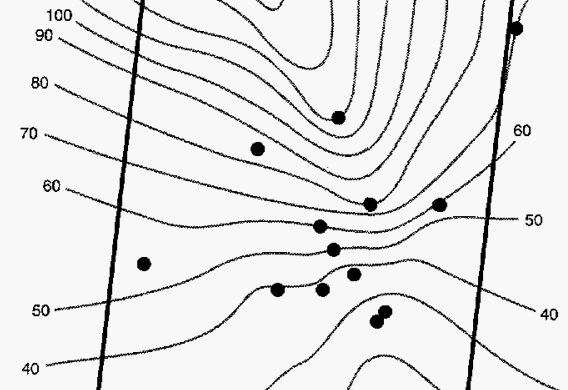

-

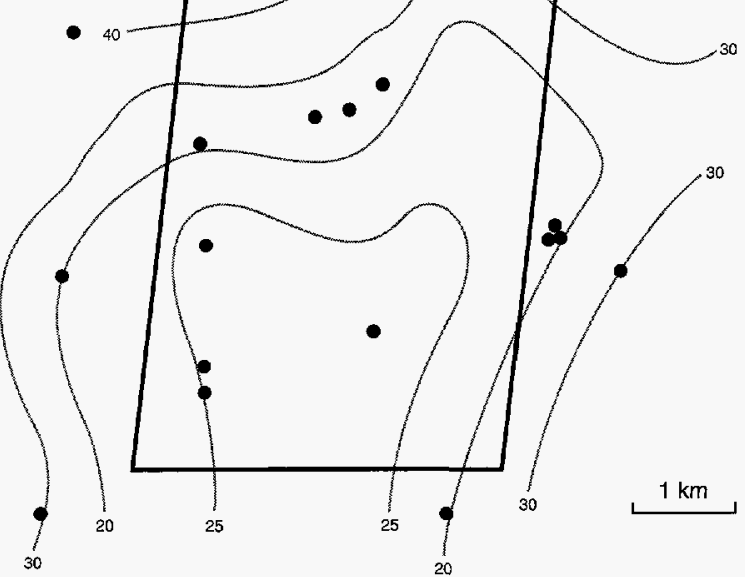

the geological unit previously published by Tien et al. ${ }^{17}$ was compared to the current hydrogeologic map. Because of the different data considered and the different area covered by the past studies, the two interpretations agree only for the most central part of the model area. Other isopach maps were published by Ortiz et al. ${ }^{29}$ for various sections of the Topopah Spring Member, e.g. the lower lithophysal zone, and the vitrophyre zone, but these maps consider only certain parts of the whole unit and cannot, therefore, be compared to the current isopach map of the Topopah Spring unit.

\subsubsection{Contour map for the water table}

The bottom of the site-scale model was defined to coincide with the water table. Although previous reports from Robison ${ }^{28}$ suggested the presence of a steep hydraulic gradient in the northern part of the model, the contour map of the water table was modified because the available data about this 
Figure 10. Isopach map (m) for Topopah Spring hydrogeologic unit.

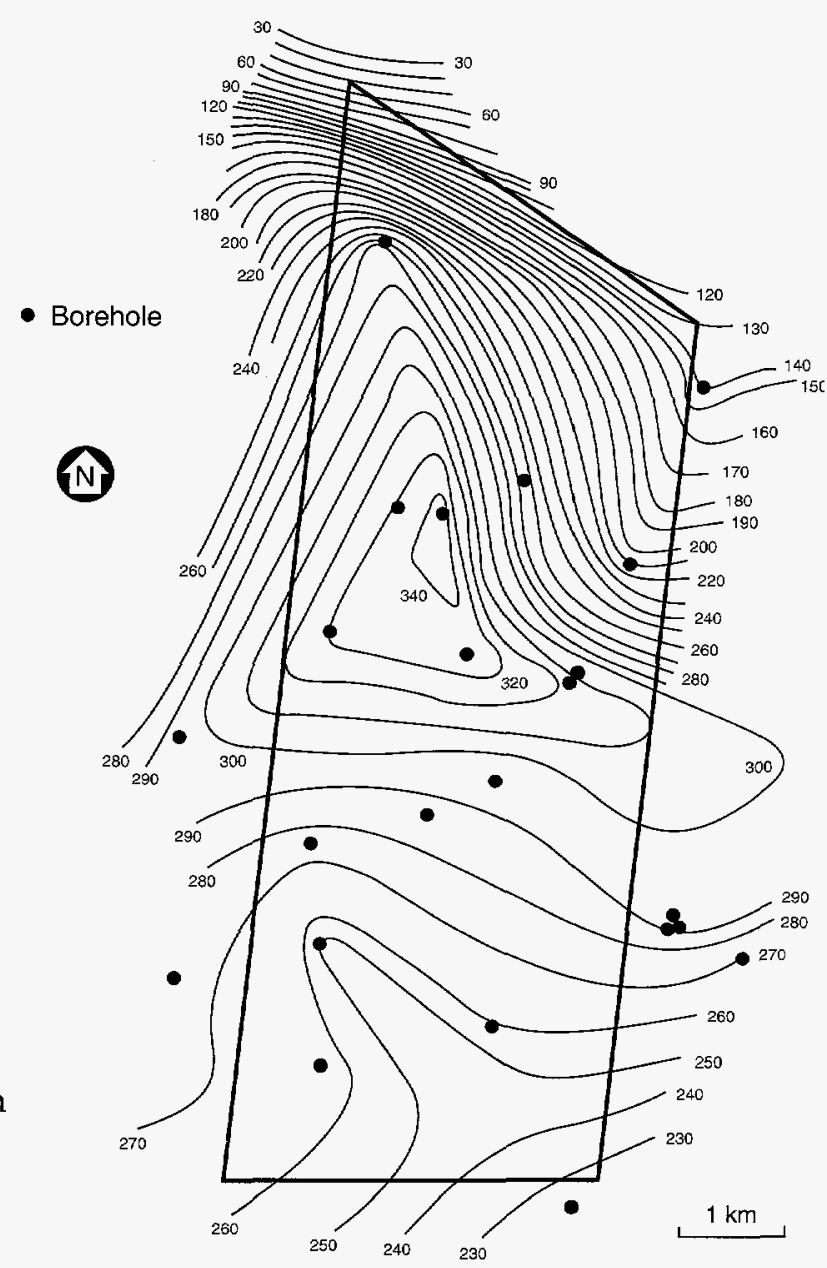

steep gradient are very limited and subject to new interpretation. Only the water elevations measured in boreholes located in the low-gradient zone were considered in the map design. Our approximate map of the water table, located at depths ranging from 380 to $860 \mathrm{~m}$. below ground surface, is presented in Figure 11.

Contour lines for $730.5,730.7$ and $731.0 \mathrm{~m}$. were extrapolated by hand to obtain more accurate information over this zone. These water level data were obtained from Ervin, et. al. ${ }^{33}$ and Gemmel ${ }^{32}$. The gradient defined between 730 and $731 \mathrm{~m}$. was extrapolated over the entire model area.

\subsubsection{Extent of vitric and zeolitic facies}

Information on the spatial distribution of the vitric and zeolitic facies within the hydrogeologic units was not precise enough to draw a map over the entire model area but the occurrence of this boundary was recorded from 
the reports about individual boreholes (see Table D in Appendix B). These values were used to define the distribution of zeolitic facies during twodimensional simulations described in Chapter 6. For a part of the model, the map of the thickness between the vitrophyre layer within the Topopah Spring hydrogeologic unit and the zone of prevalent zeolites given by Ortiz et al. $^{29}$, was used for comparison purposes.

\subsubsection{Isopach map for the Calico Hills hydrogeologic unit}

One of the results obtained from developing a three-dimensional distribution of hydrogeologic units for the site-scale model area was to define the thickness of nonwelded tuffs, called here the Calico Hills hydrogeologic unit. An isopach map, defined by calculating at each center node the thickness between the bottom boundary of the basal vitrophyre in the lower part of the Topopah Spring Member and the water table, is given in Figure 12. Below the repository area, the thickness of the unsaturated zone of the Calico Hills nonwelded hydrogeologic unit varies between 100 and $350 \mathrm{~m}$.

Figure 11. Contour map (m above sea
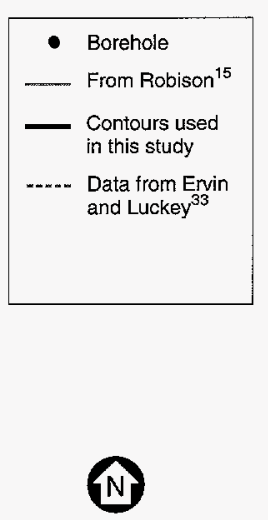

level) for the water table.

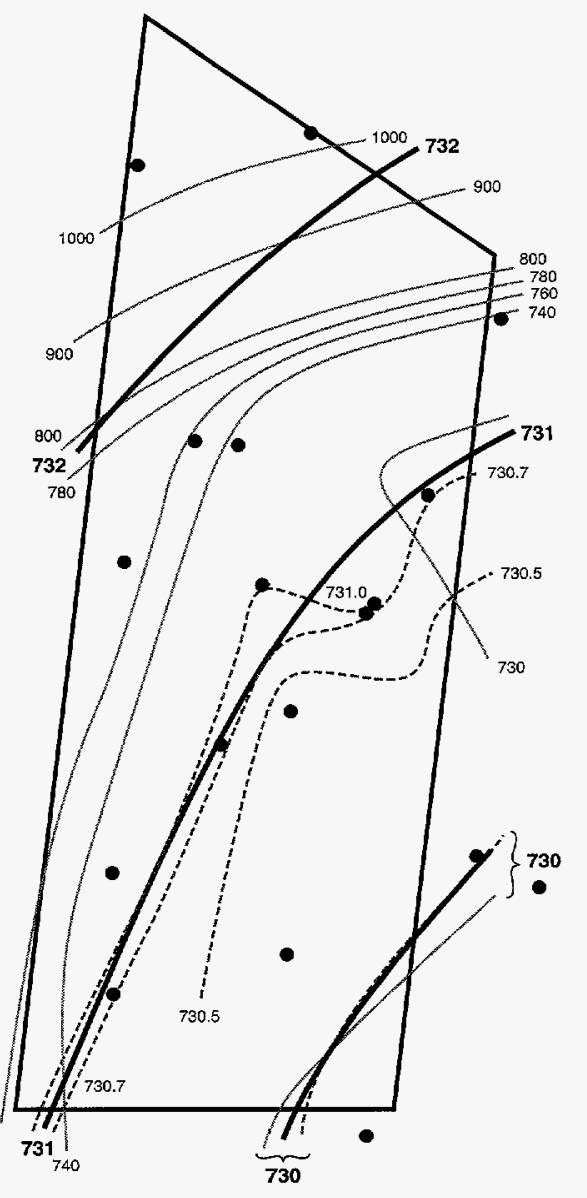


Figure 12. Isopach map (m) for the unsaturated Calico Hills hydrogeologic unit.

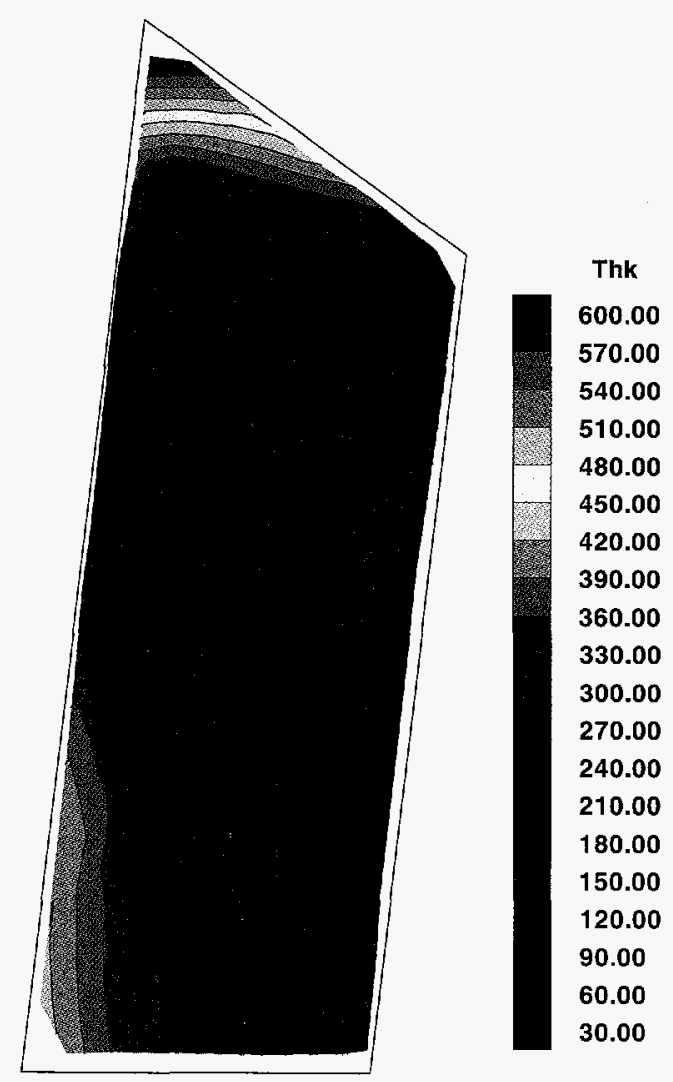

\subsection{Development of the Three-Dimensional Numerical Grid}

The vertical grid was developed on the basis of the horizontal grid composed of 286 gridblocks described above. Although the thicknesses of the units vary considerably throughout the model area, a fixed number of vertical elements was chosen for every unit. This approach allowed for a lateral continuity of the layers. At each center node, the four main hydrogeologic units were vertically subdivided into seventeen sublayers. These seventeen layers of gridblocks represent, as closely as possible, lithological variations within the main units. The sublayers also allow the use of relatively close adjacent vertical nodes at the boundaries of the hydrogeologic units to decrease grid discretization errors on simulation results due to the presence of possible strong gradients and abrupt changes in hydrogeologic properties. These include, for example, the extremely massive vitrophyre layers at the border of the main ashflows, the occurrence of lithophysae cavities within the welded units, or the presence of zeolitic alteration. The offsets along the three fault zones (Ghost Dance-, Abandoned Wash-, and Dune Wash faults) were explicitly represented within the three-dimensional grid by horizontally connecting the sublayers on each side of the faults through a double number 
of gridblocks. A mesh generator was used to create the connections, the volumes and the common surface areas of each gridblocks. The approach used, therefore, allows for the faults to be modeled explicitly, and the model geometry is consistent with the complex geology of this heavily faulted region. The computer developed grid also allows one to readily modify and adapt the non-uniform numerical grid to new data or new problems.

\subsubsection{Z-Coordinates of center node locations on unit boundaries}

The three contour maps (ground surface, Tiva Canyon hydrogeologic unit, and water table), and both isopach maps (Paintbrush- and the Topopah Spring hydrogeologic units) were digitized in relative coordinates and their format was corrected to obtain $X, Y, Z$ values. The absolute Nevada State Plane coordinates for the whole set of points were calculated by using the same program as described above in Chapter 4.1.5. The list of known Nevada State Plane coordinates used to fit the digitized values varies for each map because they are based on different set of borehole data.

The isopach map of Tiva Canyon hydrogeologic unit was subdivided into four parts which form the blocks on each side of the faults. This method was chosen to solve the contour line discontinuities at the fault offsets, and to allow for the subsequent creation of a smooth surface.

In order to obtain the Z-coordinates of the horizontal grid center nodes from those contour and isopach lines, a gridding routine called "surface gridding library" was used. This program read the points defining the contour and isopach lines and created regular grids whose accuracy between input- and calculated coordinates were controlled by statistical parameters. The Z-coordinates at the layer boundaries for each of the 286 blocks in the model domain were extracted from the regular grids. For the hydrogeologic units in the form of isopachs, the elevation of the lower unit boundary for a block was calculated by subtracting the unit thickness from the elevation found for the lower boundary of Tiva Canyon hydrogeologic unit. Because erosion has locally removed part or all of some hydrogeologic units, the number of units present at some of the center nodes was decreased by discarding data for all units located above the ground level based on the topographic map of the ground surface provided by $E G \& G^{31}$.

The entire surface of the boundary between the Tiva Canyon and Paintbrush units was created by assembling the four subparts on each side of the faults. This allowed a true elevation on both sides of the normal fault to be obtained for every center node located along the fault traces. However, the center nodes placed at the contacts between subparts without offsets were calculated as having slightly different elevations due to the gridding tech- 
nique. Those numerical artifacts were removed by simply choosing the calculated data set which was as close as possible to the values read on the contour map.

This gridding method allowed a complete set of five (or less) Z-coordinates for each center node to be obtained: at the ground surface, at the boundaries between Tiva Canyon-Paintbrush, Paintbrush-Topopah Spring, Topopah Spring - Calico Hills units, and at the water table. An example of this type of file is given in Table 4 for gridblock numbers 12 to 28. It is worthwhile to emphasize that a double set of sublayers was created for all gridblocks along faults, each set being part of the stratigraphic sequence on each side of the fault.

Table 4. Example of file with elevation of unit boundaries.

\begin{tabular}{|c|c|c|}
\hline $\begin{array}{c}\text { Grid Block } \\
\text { No. }\end{array}$ & $\begin{array}{c}\text { Boundary } \\
\text { No. }\end{array}$ & $\begin{array}{l}\text { Elevation } \\
\text { (m.a.s.l.) }\end{array}$ \\
\hline$\overline{12}$ & $\overline{0}$ & $\overline{1401.10}$ \\
\hline 12 & 3 & 1335.41 \\
\hline 12 & 5 & 732.61 \\
\hline 13 & 0 & 1413.45 \\
\hline 13 & 2 & 1376.84 \\
\hline 13 & 3 & 1280.83 \\
\hline 13 & 5 & 732.54 \\
\hline 14 & 0 & 1350.40 \\
\hline 14 & 2 & 1342.88 \\
\hline 14 & 3 & 1221.82 \\
\hline 14 & 5 & 732.44 \\
\hline 15 & 0 & 1338.71 \\
\hline 15 & 2 & 1316.44 \\
\hline 15 & 3 & 1184.38 \\
\hline 15 & 5 & 732.31 \\
\hline 16 & 0 & 1299.94 \\
\hline 16 & 2 & 1299.25 \\
\hline 16 & 3 & 1165.97 \\
\hline 16 & 5 & 732.17 \\
\hline 17 & 0 & 1268.00 \\
\hline 17 & 3 & 1131.48 \\
\hline 17 & 5 & 732.01 \\
\hline 18 & 0 & 1262.62 \\
\hline 18 & 2 & 1240.83 \\
\hline 18 & 3 & 1107.59 \\
\hline
\end{tabular}


Table 4. Example of file with elevation of unit boundaries.

\begin{tabular}{|c|c|c|}
\hline $\begin{array}{c}\text { Grid Block } \\
\text { No. }\end{array}$ & $\begin{array}{c}\text { Boundary } \\
\text { No. }\end{array}$ & $\begin{array}{c}\text { Elevation } \\
\text { (m.a.s.l.) }\end{array}$ \\
\hline \hline 18 & 5 & 731.88 \\
\hline 27 & 0 & 1552.26 \\
\hline 27 & 1 & 1527.04 \\
\hline 27 & 2 & 1361.20 \\
\hline 27 & 3 & 1152.21 \\
\hline 27 & 5 & 732.53 \\
\hline 28 & 0 & 1410.85 \\
\hline 28 & 2 & 1330.14 \\
\hline 28 & 3 & 1125.04 \\
\hline 28 & 5 & 732.42 \\
\hline Boundary No: & \multicolumn{3}{|c|}{} \\
$0=$ Ground Surface \\
1 = Boundary Tiva Canyon-Paintbrush \\
2 = Boundary Paintbrush-Topopah Spring \\
3 = Boundary Topopah Spring-Calico Hills \\
5 = Water Table \\
m.a.s.l. = meters above sea level \\
\hline
\end{tabular}

\subsubsection{Subdivision of the hydrogeologic units}

The four main hydrogeologic units were divided into 17 sublayers. The use of the sublayers also allows relatively thin layers at the boundaries of the hydrogeologic units to decrease grid discretization errors on simulation results due to the possible presence of strong gradients and abrupt changes in hydrogeologic properties. The number of sublayers for each hydrogeologic unit was also chosen so as to represent, as closely as possible, lithological variations across the unit and resultant changes in hydrogeologic parameters. These include, for example, the vitrophyre layers at the border of the main ashflows, the occurrence of lithophysae cavities within the welded units, or the presence of zeolitic alteration important in the Calico Hills unit. Because the thickness of each unit greatly varies over the model area, a set of rules was defined to subdivide each unit. The rules provided a way to make the sublayers adjacent to hydrogeologic unit boundaries somewhat consistent in thickness across the model domain. The Tiva Canyon unit varies from 0 to $201 \mathrm{~m}$, and was divided into three sublayers. The Paintbrush unit, up to $171 \mathrm{~m}$ thick, was also divided into three sublayers. Six sublayers were assigned to the thick (66 to $367 \mathrm{~m}$ ) Topopah Spring unit, and five sublayers to the Calico Hills unit, which reaches $603 \mathrm{~m}$ in thickness. 
In order to keep a constant number of sublayers within each unit, a percentage of the whole unit thickness was assigned to each of the sublayers, with thinner sublayers chosen to surround the unit boundaries to resolve high gradients which may occur there. These percentages were varied across the model domain to provide relatively consistent boundary layer thicknesses. For example, the total number of Tiva Canyon hydrogeologic unit gridblocksis plotted versus thickness in 5 meter intervals in Figure 13.

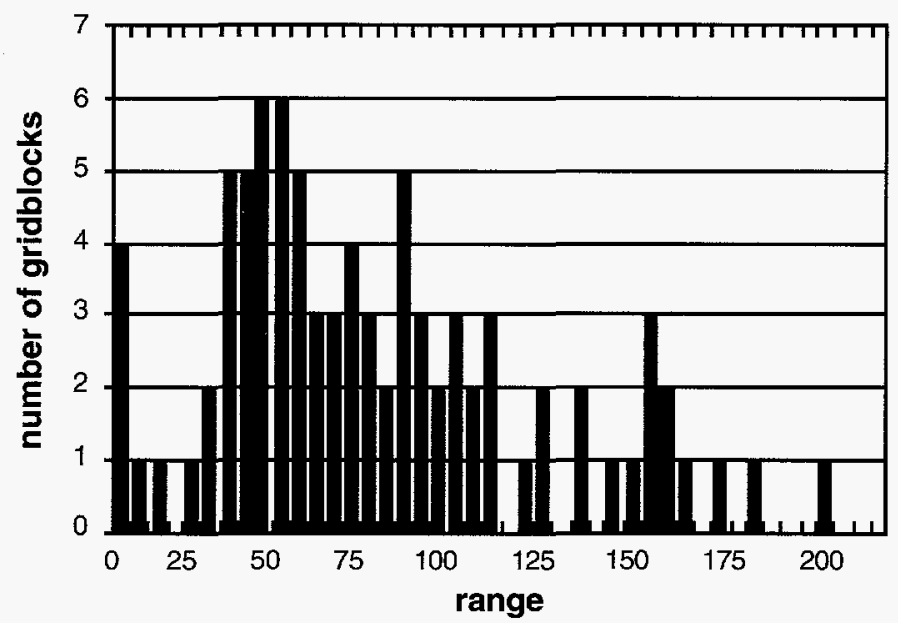

Figure 13. Distribution of layer thicknesses for the Tiva Canyon hydrogeologic unit gridblocks.

Based on the thickness distribution over the model area, rules shown in Table 5 were applied to each of the hydrogeologic units and their total thickness at the center node locations of the horizontal grid was subdivided to create the three to six sublayers. A program was written to automatically create those sublayers. It needs as input files: the $X-Y$ coordinates of the center nodes, the elevation file described above with boundaries of units, and the set of dividing rules. An example of the output file containing sublayer number, $X-, Y-, Z$ - coordinates for the center nodes of each gridblock and its thickness is shown in Table 6. This file was used as input for the threedimensional mesh generation. 
Table 5. Subdivisions of hydrogeological units.

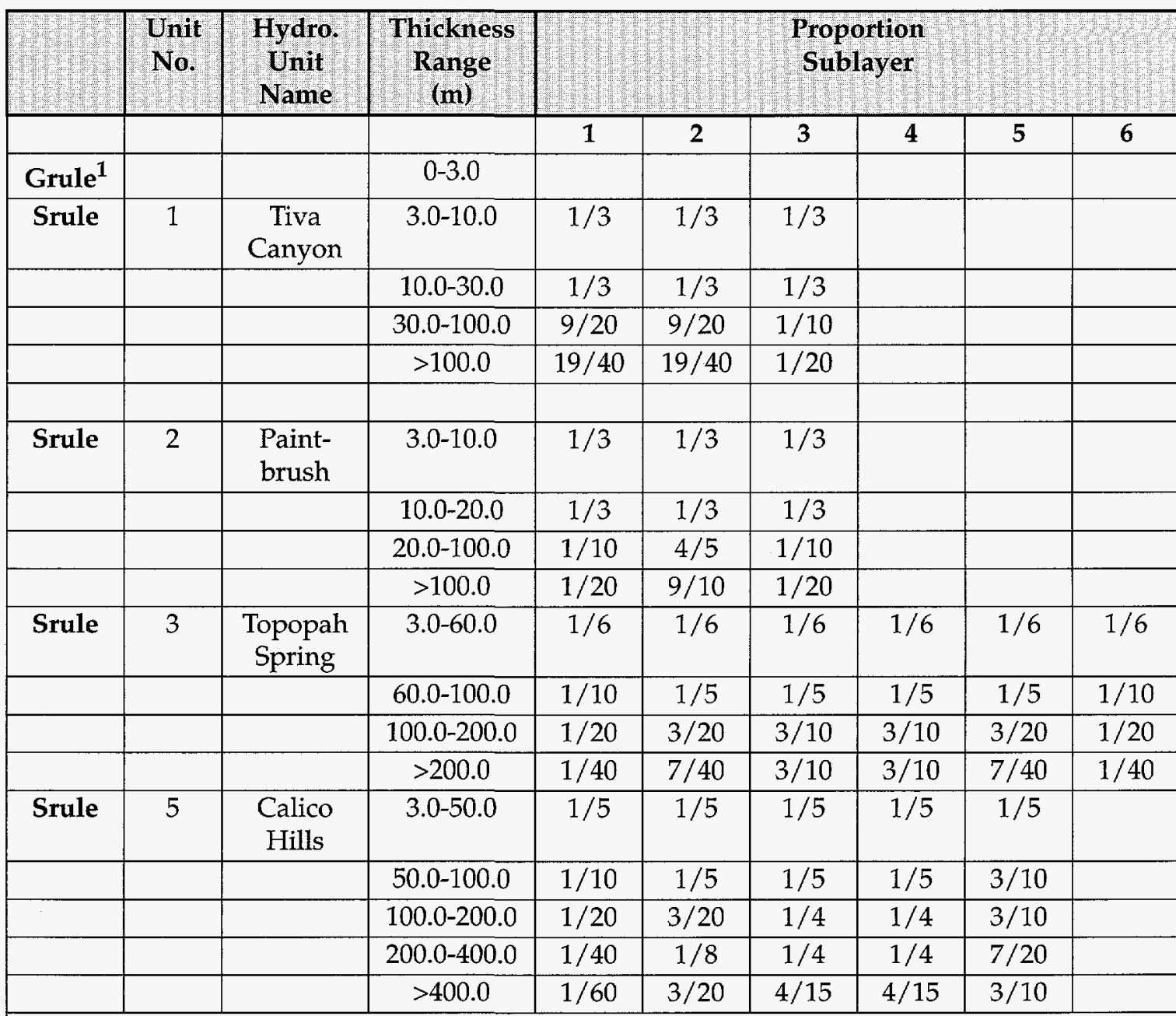

Note: 1 - A general rule is set so that if computed thickness of a hydrogeologic unit is $<3 \mathrm{~m}$, the unit is assumed to be non-existent. 
Table 6. Example of coordinate-file for the three-dimensional grid.

\begin{tabular}{|c|c|c|c|c|c|}
\hline $\begin{array}{l}\text { Grid } \\
\text { Block } \\
\text { No. }\end{array}$ & $\begin{array}{l}\text { Sub- } \\
\text { layer No. }\end{array}$ & $\begin{array}{c}\text { North } \\
\text { Nevada } \\
\text { Coordinate } \\
\text { (m) }\end{array}$ & $\begin{array}{c}\text { East } \\
\text { Nevada } \\
\text { Coordinate } \\
(\mathbf{m})\end{array}$ & $\begin{array}{c}\text { Elevation } \\
\text { (m) }\end{array}$ & $\begin{array}{c}\text { Thickness } \\
\text { (m) }\end{array}$ \\
\hline 3112 & $\overline{31}$ & 238585.08 & 171044.19 & $\overline{1397.815}$ & 6.569 \\
\hline 3212 & 32 & 238585.08 & 171044.19 & 1387.962 & 13.138 \\
\hline 3312 & 33 & 238585.08 & 171044.19 & 1374.824 & 13.138 \\
\hline 3412 & 34 & 238585.08 & 171044.19 & 1361.686 & 13.138 \\
\hline 3512 & 35 & 238585.08 & 171044.19 & 1348.548 & 13.138 \\
\hline 3612 & 36 & 238585.08 & 171044.19 & 1338.694 & 6.569 \\
\hline 5112 & 51 & 238585.08 & 171044.19 & 1330.386 & 10.046 \\
\hline 5212 & 52 & 238585.08 & 171044.19 & 1280.153 & 90.420 \\
\hline 5312 & 53 & 238585.08 & 171044.19 & 1154.570 & 160.746 \\
\hline 5412 & 54 & 238585.08 & 171044.19 & 993.823 & 160.746 \\
\hline 5512 & 55 & 238585.08 & 171044.19 & 823.030 & 180.840 \\
\hline 2113 & 21 & 238347.42 & 171339.10 & 1411.619 & 3.661 \\
\hline 2213 & 22 & 238347.42 & 171339.10 & 1395.145 & 29.288 \\
\hline 2313 & 23 & 238347.42 & 171339.10 & 1378.670 & 3.661 \\
\hline 3113 & 31 & 238347.42 & 171339.10 & 1372.039 & 9.601 \\
\hline 3213 & 32 & 238347.42 & 171339.10 & 1357.638 & 19.202 \\
\hline 3313 & 33 & 238347.42 & 171339.10 & 1338.436 & 19.202 \\
\hline 3413 & 34 & 238347.42 & 171339.10 & 1319.234 & 19.202 \\
\hline 3513 & 35 & 238347.42 & 171339.10 & 1300.032 & 19.202 \\
\hline 3613 & 36 & 238347.42 & 171339.10 & 1285.630 & 9.601 \\
\hline 5113 & 51 & 238347.42 & 171339.10 & 1276.260 & 9.138 \\
\hline 5213 & 52 & 238347.42 & 171339.10 & 1230.570 & 82.243 \\
\hline 5313 & 53 & 238347.42 & 171339.10 & 1116.343 & 146.210 \\
\hline 5413 & 54 & 238347.42 & 171339.10 & 970.132 & 146.210 \\
\hline 5513 & 55 & 238347.42 & 171339.10 & 814.783 & 164.487 \\
\hline
\end{tabular}

\subsubsection{Numerical grid}

The same mesh generator described above for the horizontal two-dimensional grid was adapted to generate the three-dimensional grid. In order to take into account the fault offsets within the columns of gridblocks located along the fault traces, the generation of the numerical grid was performed in two steps: first by dealing with all gridblocks except those with offsets, then by taking care of gridblocks with offsets. These two grids were finally com- 
bined to obtain the three-dimensional numerical grid for the whole site-scale model area.

The mesh generator had to be used more than once to create the right connection lengths, volumes, and interface surfaces because the number of vertical gridblocks in the fault areas was twice as large as that in the surrounding gridblocks.

\subsubsection{All gridblocks except those with offsets}

The principal difficulty of generating the grid was to obtain the correct volumes and interfaces for the gridblocks adjacent to the faults. For that purpose, the mesh generator was run three times for the different subregions of the whole grid. Each of those subregions was partly bounded by faults, and mesh generation for that subregion included the adjacent fault gridblocks. For example, one subregion was composed of all gridblocks located at the eastern side of Ghost Dance- and Dune Wash faults. Another was bounded by the Dune Wash- and Abandoned Wash faults. The last one included all gridblocks on the western side of Ghost Dance-, and Abandoned Wash faults. The three subregions were finally combined and all data (volumes, connections, interfaces) regarding the gridblocks located along the western and eastern subregions were checked, and manually manipulated to obtain the complete grid.

\subsubsection{Gridblocks with offsets}

The major problem in generating gridblocks located along the fault traces was to find a method which maintains the sudden stratigraphic offset but also connects the adjacent gridblocks to the fault zone itself.

It was decided to create a double number of sublayers for the fault-gridblocks, and to adapt the mesh generator in order to connect them by their common interfaces to the adjacent gridblocks. A schematic representation of this grid design is given in Figure 14.

In order to obtain the correct volumes and interfaces for the gridblocks in the fault zones, it was necessary to create dummy-gridblocks adjacent to each fault-gridblock. In the columns adjacent to the fault, these dummies were located at the center nodes of each sublayers. Their thicknesses were determined by applying the same thickness ratio as the one calculated in the fault zone for all gridblocks with common interfaces. In the fault zone itself, additional gridblocks were created and named on the basis of adjacent gridblocks for which volume, connection length, and interface surfaces were being calculated.

The names of the dummy-gridblocks were particularly long in order to recognize which dummies were forming pairs with the fault-gridblocks. It 


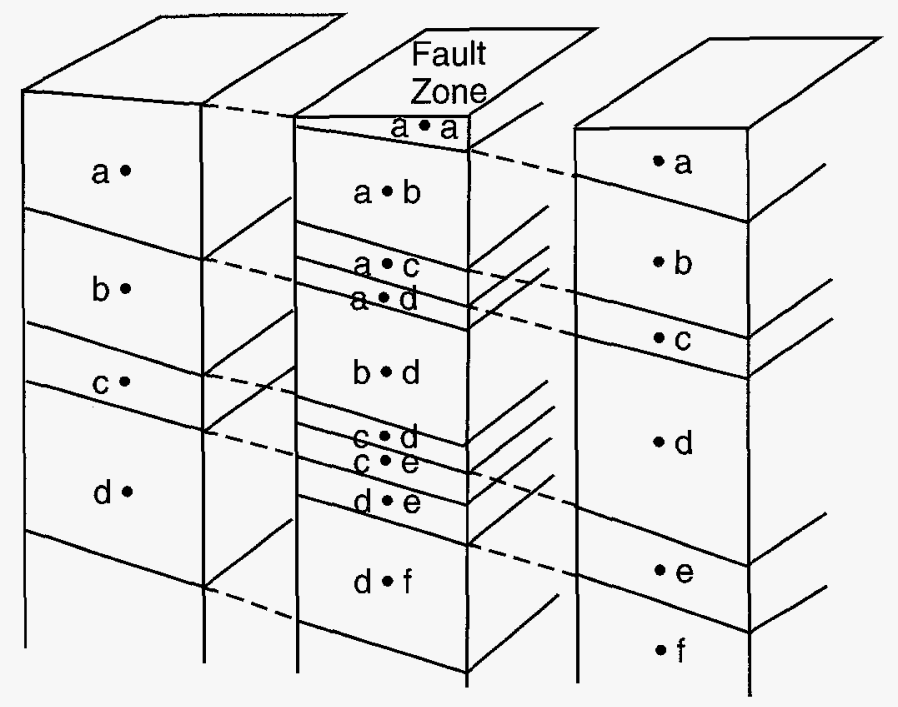

Figure 14. Example of grid design near fault zones.

was therefore necessary to change the format within the mesh generator to deal with this special case. The mesh generator, when used for fault-gridblocks and their adjacent gridblocks, therefore produced a large number of connections and volumes for each gridblock and its surrounding dummies. The relevant dataset for a fault-gridblock was manually extracted out of these output files. This includes their volumes, as well as their vertical and lateral connections and interfaces. All data concerning the dummy gridblocks were then discarded.

\subsubsection{Combining both grids}

Various programs were written to choose, check, and recombine the files with connections and volumes from those two mesh generations. One of the programs reads, for example, all connection and gridblock names within the output files and corrects them if they have been transposed during subsequent runs of the mesh generator.

Another program combines gridblocks and their connections from different output files of the mesh generator. It removes all data concerning the fault-gridblocks created during the generation of the grid for the entire model area except the fault (see section 4.3.3.1). On the other hand, it only includes data concerning the fault-gridblocks from the output files created by the second mesh generation (see section 4.3.3.2). Within this last connection file, the names of the gridblocks adjacent to the fault were corrected because the dummies used to create those lateral connection had different names, i.e. similar to their neighbor in the fault zone with double number of sublayers 
compared to the rest of the model area. This program also allowed the addition of a thin bottom layer of gridblocks over the entire model area. Large volumes were assigned to this last layer in order to enforce time-invariant boundary conditions, such as complete saturation, during numerical simulations.

\section{Rock Properties}

Once the geometry of the site-scale model was set, physical and hydrogeologic properties for the different hydrogeologic units and corresponding sublayers were defined for the rock matrix, the fractured medium, and the fault zones based on data reported in previous studies.

Numerous data have been compiled in previous studies. In order to obtain values for the seventeen sublayers of the model, these data were gathered and used to produce a dataset adapted to the geometry of the site-scale model. Rulon et al. ${ }^{1}$ used values given by Scott et al. ${ }^{18}$, and Montazer and Wilson ${ }^{7}$ for their two-dimensional simulations with five hydrogeologic units. Peters et al. ${ }^{34}$ also proposed a set of representative values for six types of units within the unsaturated zone. Rock properties for the nonwelded units published by Flint and Flint ${ }^{19}$, such as porosities, air and water permeabilities, and grain densities, were used to refine the properties of these units. Other rock properties were obtained from surface samples taken, for example, along a vertical transect on the east side of Solitario Canyon near the location of borehole USW UZ-6. These measurements provided a great number of data for rocks between the Tiva Canyon and the Calico Hills hydrogeologic units ${ }^{11}$. Moisture retention curves were also reported for these samples, and this composite dataset was the primary source of van Genuchten parameters in the modeling. Laboratory analysis of core samples from borehole USW GU-3 ${ }^{37}$ provided additional data, especially for the lower part of the unsaturated zone. Available information from the database developed at Sandia National Laboratories (Scientific and Engineering Properties Database [SEPDB], superseded by the Technical Database managed by EG\&G) were also used to compare data for porosity and density for eight of the boreholes. Data from geophysical logs and core measurements from $\mathrm{Nel}-$ son et al. ${ }^{39}$ allowed the grouping of various lithologies within hydrogeologic units with near-homogeneous porosity values. The assumption that porosity is, even in the fractured welded units, the controlling factor for matrix flow properties was suggested by Montazer and Wilson ${ }^{7}$. They noted that the welding process, to which fracture density can also be related, resulted in small matrix porosity and small pore sizes, and therefore affects the matrix permeability. 
All of the above information helped determine representative values for the three-dimensional grid, but also provided the basis for deciding which lithological zones within a geologic member could be regrouped into one model hydrogeologic sublayer, or on the contrary, which zones must be independently considered because of different hydrogeologic characteristics.

\subsection{Matrix Properties}

Besides the schematic description of the lithology for each sublayers, the dataset given in Table 7 shows the range of porosities and saturated permeabilities reported in the literature, as well as the values chosen for the numerical simulations described below. Values for air entry pressure and the van Genuchten parameters $(n, m)$ given in Table 7 were based on data given in Flint and Flint ${ }^{11}$. These parameters define the characteristic curves for matric potential versus liquid saturation, and the relative permeability functions were calculated using the method proposed by van Genuchten ${ }^{13}$, and Hayden et $a .^{35}$.

Because zeolitization greatly reduces the permeability of the rock, the influence of zeolitization was considered in the model by changing the hydrologic parameters for areas where the rocks are highly altered.

It should be mentioned that measured data were missing for some of the parameters. For example, no capillary pressure curves were available for sublayer 1.1 (upper part of the Tiva Canyon unit), sublayer 1.3 (vitrophyre at the base of the Tiva Canyon unit), and only one set of data was reported for the zeolitized part of the Calico Hills unit. Furthermore, permeability data were not available for the low porosity vitrophyre (sublayer 3.1), or within the nonwelded tuffs of the Calico Hills (sublayers 5.1 and 5.3). It was therefore necessary to assume that data reported for similar types of rocks were also representative for those sublayers.

It should also be noted that the data given in Table 7 can only be considered as current estimates, and will be subject to changes as the sitecharacterization studies proceed. The representative values used for the model sublayers were therefore chosen based upon the distribution of the measured parameter values, the locations of the samples within the different units, and the lithological similarities between and within each of the hydrogeologic sublayers. In some cases the hydrogeologic parameters used in the model are outside the reported range as determined by a limited number of measured values. This occurred where data from other sublayers with similar porosities showed a broader range of values than the sublayer in question. 
Table 7. Rock matrix properties for the seventeen model sublayers derived from the four hydrogeologic units.

\begin{tabular}{|c|c|c|c|c|c|c|c|c|c|}
\hline \multirow{2}{*}{$\begin{array}{c}\text { Hydro- } \\
\text { geologic Unit }\end{array}$} & \multirow{2}{*}{$\begin{array}{c}\text { Geologic } \\
\text { Zone, per } \\
\text { Scott \& } \\
\text { Bonk }^{9}\end{array}$} & \multirow{2}{*}{$\begin{array}{l}\text { Model } \\
\text { Sub- } \\
\text { Layer }\end{array}$} & \multicolumn{2}{|c|}{ Porosity } & \multicolumn{2}{|c|}{ Permeability } & \multirow{2}{*}{$\begin{array}{c}\alpha \times 10^{-5} \\
\left(\mathrm{~Pa}^{-1}\right)\end{array}$} & \multirow[t]{2}{*}{ n } & \multirow[t]{2}{*}{ m } \\
\hline & & & $\begin{array}{c}\text { Range } \\
(\%)\end{array}$ & $\begin{array}{c}\text { Model } \\
(\%)\end{array}$ & Range $\left(\mathrm{m}^{2}\right)$ & Model $\left(\mathrm{m}^{2}\right)$ & & & \\
\hline \multirow{8}{*}{$\begin{array}{l}\text { Tiva Canyon } \\
\text { (welded tuff) }\end{array}$} & caprock & \multirow{4}{*}{1.1} & \multirow{4}{*}{$6-24$} & \multirow{4}{*}{17} & \multirow{4}{*}{$2 \mathrm{E}-19-2 \mathrm{E}-14$} & \multirow{4}{*}{$1 \mathrm{E}-18$} & \multirow{4}{*}{$\begin{array}{c}0.067 \\
\text { (Same as } \\
1.2 \text { ) }\end{array}$} & \multirow{4}{*}{1.33} & \multirow{4}{*}{0.250} \\
\hline & upper cliff & & & & & & & & \\
\hline & $\begin{array}{l}\text { upper } \\
\text { lithophysae }\end{array}$ & & & & & & & & \\
\hline & $\begin{array}{l}\text { clinkstone } \\
\text { zone }\end{array}$ & & & & & & & & \\
\hline & $\begin{array}{l}\text { lower } \\
\text { lithophysae }\end{array}$ & \multirow[t]{3}{*}{1.2} & \multirow[t]{3}{*}{$6-28$} & \multirow[t]{3}{*}{17} & \multirow[t]{3}{*}{$1 \mathrm{E}-20-2 \mathrm{E}-16$} & \multirow[t]{3}{*}{$2 \mathrm{E}-18$} & \multirow[t]{3}{*}{0.067} & \multirow[t]{3}{*}{1.33} & \multirow[t]{3}{*}{0.250} \\
\hline & hackly zone & & & & & & & & \\
\hline & $\begin{array}{l}\text { columnar } \\
\text { zone }\end{array}$ & & & & & & & & \\
\hline & vitrophyre & 1.3 & $2-10$ & 6 & $4 \mathrm{E}-17-1 \mathrm{E}-15$ & $\begin{array}{c}1 \mathrm{E}-18 \\
\text { (Assumed } \\
\text { similar to } 1.2 \text { ) }\end{array}$ & $\begin{array}{c}0.067 \\
\text { (Same as } \\
1.2 \text { ) }\end{array}$ & 1.33 & 0.250 \\
\hline \multirow{4}{*}{$\begin{array}{l}\text { Paintbrush } \\
\text { (nonwelded } \\
\text { tuff) }\end{array}$} & shardy base & 2.1 & $12-54$ & 33 & $1 \mathrm{E}-17-5 \mathrm{E}-13$ & $1 \mathrm{E}-13$ & 1.67 & 1.20 & 0.167 \\
\hline & $\begin{array}{l}\text { nonwelded } \\
\text { tuffs }\end{array}$ & \multirow[t]{2}{*}{2.2} & \multirow[t]{2}{*}{$18-57$} & \multirow[t]{2}{*}{37} & \multirow[t]{2}{*}{$5 \mathrm{E}-16-5 \mathrm{E}-12$} & \multirow[t]{2}{*}{$5 E-14$} & \multirow[t]{2}{*}{6.00} & \multirow[t]{2}{*}{1.19} & \multirow[t]{2}{*}{0.163} \\
\hline & bedded tuffs & & & & & & & & \\
\hline & $\begin{array}{l}\text { nonwelded } \\
\text { tuffs }\end{array}$ & 2.3 & $10-55$ & 32 & $4 \mathrm{E}-16-6 \mathrm{E}-13$ & $1 \mathrm{E}-13$ & 4.33 & 1.17 & 0.142 \\
\hline
\end{tabular}


Table 7. Rock matrix properties for the seventeen model sublayers derived from the four hydrogeologic units.

\begin{tabular}{|c|c|c|c|c|c|c|c|c|c|}
\hline \multirow{2}{*}{$\begin{array}{l}\text { Hydro- } \\
\text { geologic Unit }\end{array}$} & \multirow{2}{*}{$\begin{array}{c}\text { Geologic } \\
\text { Zone, per } \\
\text { Scott \& } \\
\text { Bonk }^{9}\end{array}$} & \multirow{2}{*}{$\begin{array}{c}\text { Model } \\
\text { Sub- } \\
\text { Layer }\end{array}$} & \multicolumn{2}{|c|}{ Porosity } & \multicolumn{2}{|c|}{ Permeability } & \multirow{2}{*}{$\begin{array}{c}\alpha \times 10^{-5} \\
\left(\mathrm{~Pa}^{-1}\right)\end{array}$} & \multirow[t]{2}{*}{$\mathrm{n}$} & \multirow[t]{2}{*}{ m } \\
\hline & & & $\begin{array}{c}\text { Range } \\
(\%)\end{array}$ & $\begin{array}{c}\text { Model } \\
(\%)\end{array}$ & Range $\left(\mathrm{m}^{2}\right)$ & $\operatorname{Model}\left(\mathrm{m}^{2}\right)$ & & & \\
\hline \multirow[t]{8}{*}{$\begin{array}{l}\text { Topopah } \\
\text { Spring } \\
\text { (welded tuff) }\end{array}$} & vitrophyre & 3.1 & $3-9$ & 6 & $\begin{array}{c}\text { (Assumed } \\
\text { same as 3.6) }\end{array}$ & $1 \mathrm{E}-18$ & $\begin{array}{c}0.067 \\
\text { (Assum- } \\
\text { ed same } \\
\text { as 3.6) }\end{array}$ & 1.41 & 0.290 \\
\hline & caprock & 3.2 & $9-22$ & 15 & $8 \mathrm{E}-17-4 \mathrm{E}-14$ & $4 \mathrm{E}-16$ & 0.125 & 1.22 & 0.180 \\
\hline & $\begin{array}{l}\text { rounded } \\
\text { zone }\end{array}$ & & & & & & & & \\
\hline & $\begin{array}{l}\text { upper } \\
\text { lithophysae }\end{array}$ & 3.3 & $10-16$ & 13 & $5 \mathrm{E}-20-3 \mathrm{E}-18$ & $4 \mathrm{E}-18$ & 0.20 & 1.28 & 0.220 \\
\hline & $\begin{array}{l}\text { middle non- } \\
\text { lithophysae }\end{array}$ & 3.4 & $6-22$ & 14 & $4 \mathrm{E}-20-1 \mathrm{E}-17$ & $5 E-18$ & 0.133 & 1.33 & 0.250 \\
\hline & $\begin{array}{l}\text { lower } \\
\text { lithophysae }\end{array}$ & & & & & & & & \\
\hline & $\begin{array}{l}\text { lower non- } \\
\text { lithophysae }\end{array}$ & 3.5 & $6-18$ & 12 & $4 \mathrm{E}-20-1 \mathrm{E}-17$ & $5 \mathrm{E}-18$ & 0.067 & 1.33 & 0.250 \\
\hline & vitrophyre & 3.6 & $1-10$ & 5 & $5 \mathrm{E}-20-2 \mathrm{E}-17$ & $1 \mathrm{E}-18$ & 0.067 & 1.41 & 0.290 \\
\hline
\end{tabular}


Table 7. Rock matrix properties for the seventeen model sublayers derived from the four hydrogeologic units.

\begin{tabular}{|c|c|c|c|c|c|c|c|c|c|}
\hline \multirow{2}{*}{$\begin{array}{l}\text { Hydro- } \\
\text { geologic Unit }\end{array}$} & \multirow{2}{*}{$\begin{array}{l}\text { Geologic } \\
\text { Zone, per } \\
\text { Scott \& } \\
\text { Bonk }^{9}\end{array}$} & \multirow{2}{*}{$\begin{array}{l}\text { Model } \\
\text { Sub- } \\
\text { Layer }\end{array}$} & \multicolumn{2}{|c|}{ Porosity } & \multicolumn{2}{|c|}{ Permeability } & \multirow{2}{*}{$\begin{array}{c}\alpha \times 10^{-5} \\
\left(\mathbf{P a}^{-1}\right)\end{array}$} & \multirow[t]{2}{*}{ n } & \multirow[t]{2}{*}{$\mathrm{m}$} \\
\hline & & & $\begin{array}{c}\text { Range } \\
(\%)\end{array}$ & $\begin{array}{c}\text { Model } \\
(\%)\end{array}$ & Range $\left(\mathrm{m}^{2}\right)$ & $\operatorname{Model}\left(\mathbf{m}^{2}\right)$ & & & \\
\hline \multirow{8}{*}{$\begin{array}{l}\text { Calico Hills } \\
\text { (nonwelded } \\
\text { tuff) }\end{array}$} & bedded tuffs & 5.1 & $23-48$ & 35 & $\begin{array}{c}\text { (Assumed } \\
\text { similar to } 5.2 \text { ) }\end{array}$ & $2 \mathrm{E}-13$ & 2.0 & 1.15 & 0.130 \\
\hline & $\begin{array}{l}\text { nonwelded } \\
\text { vitric }\end{array}$ & \multirow[t]{2}{*}{5.2} & \multirow[t]{2}{*}{$8-48$} & \multirow[t]{2}{*}{28} & \multirow[t]{2}{*}{$1 E-18-2 E-15$} & \multirow[t]{2}{*}{$3 E-13$} & \multirow[t]{2}{*}{2.0} & \multirow[t]{2}{*}{1.14} & \multirow[t]{2}{*}{0.120} \\
\hline & bedded tuffs & & & & & & & & \\
\hline & $\begin{array}{l}\text { nonwelded } \\
\text { tuffs }\end{array}$ & 5.3 & $30-48$ & 39 & $\begin{array}{c}\text { (Assumed } \\
\text { same as 5.2) }\end{array}$ & $3 E-13$ & 2.0 & 1.14 & 0.120 \\
\hline & $\begin{array}{l}\text { slightly zeoli- } \\
\text { tized }\end{array}$ & \multirow{4}{*}{$\begin{array}{l}5.4 \\
5.5\end{array}$} & \multirow{4}{*}{$14-36$} & \multirow{4}{*}{25} & \multirow{4}{*}{ 5E-19 - 7E-17 } & \multirow{4}{*}{$1 E-16$} & \multirow{4}{*}{0.1} & \multirow{4}{*}{1.23} & \multirow{4}{*}{0.190} \\
\hline & $\begin{array}{l}\text { zeolitized, } \\
\text { partly argillic }\end{array}$ & & & & & & & & \\
\hline & $\begin{array}{l}\text { zeolitized, } \\
\text { devitrified }\end{array}$ & & & & & & & & \\
\hline & zeolitized & & & & & & & & \\
\hline
\end{tabular}

a. Footnotes to Table 11

Porosity Data from Flint and Flint ${ }^{11,} 19$, SEPDB and USGS ${ }^{37}$

Permeability Data from Flint and Flint ${ }^{11,} 19$

van Genuchten parameters based on Flint and Flint ${ }^{11}$ 
The van Genuchten mode ${ }^{13}$ used in the numerical simulations to account for the relationship between the effective saturation $S_{e}$, and the capillary pressure $P_{\text {cap }}$ is based on the following equation:

$$
\mathrm{S}_{\mathrm{e}}=\left[1+\left(\alpha \cdot \mathrm{P}_{\text {cap }}\right)^{\mathrm{n}}\right]^{-\mathrm{m}}
$$

where:

$$
S_{e}=\frac{S_{1}-S_{r}}{S_{s}-S_{r}}
$$

with: $\quad \mathrm{S}_{1} \quad=$ liquid saturation

$\mathrm{S}_{\mathrm{r}} \quad=$ residual saturation

$\mathrm{S}_{\mathrm{S}} \quad=$ satiated saturation

$\mathrm{P}_{\text {cap }} \quad=$ capillary pressure

$\mathrm{m} \quad=1-1 / \mathrm{n}$

$\alpha, \mathrm{n} \quad=$ empirical fitting parameters

The moisture retention measurements performed on core and surface samples by Flint and Flint ${ }^{11}$ were used in this study. Fitting parameters were used to obtain the two empirical parameters of the van Genuchten model ${ }^{13}$. The van Genuchten parameters shown in Table 7 for the seventeen sublayers in the model were chosen from the entire data set in order to represent the characteristic curves of each rock type. On the other hand, values for layers which have not been explicitly measured (for example, sublayer 1.1 in the Tiva Canyon unit, and sublayer 5.3 in the Calico Hills unit) were again taken from rock samples with similar lithologies. The capillary pressure curves calculated with the van Genuchten model are given in Figure 15 for the nonwelded units, and Figure 16 for the welded units. They were chosen by plotting the various datasets of measured values for the same lithology, and by determining mean values, or even by discarding some of the less reliable data.

The van Genuchten model was also used to calculate the relative permeability curves for the rock matrix. The relationship between relative permeability $\mathrm{k}_{\text {rel }}$ and effective saturation is given by:

$$
k_{r e l}=\sqrt{S_{e}}\left\{1-\left[1-\left(S_{e}\right)^{1 / m}\right]^{m}\right\}^{2}
$$

This approach therefore predicts both characteristic curves of the unsaturated rock matrix for the seventeen model sublayers by measuring only one of the relationships. 

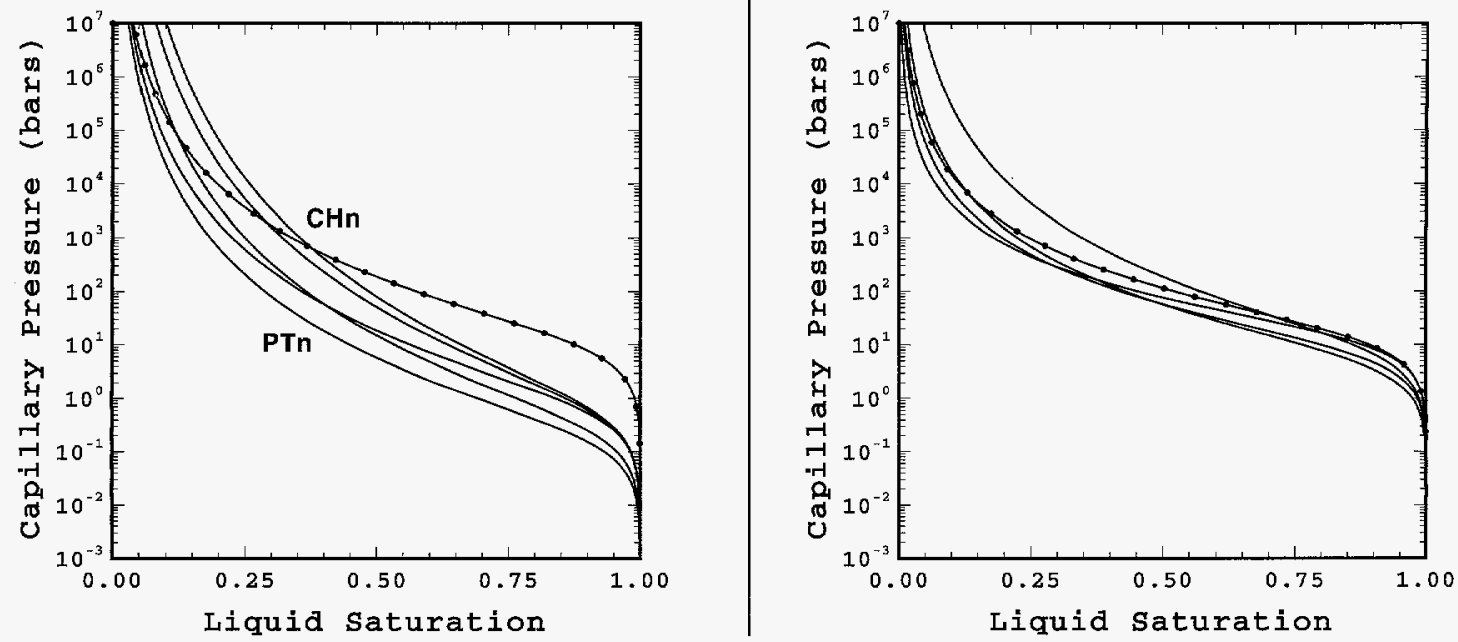

Figure 15. Capillary pressure curves for the Figure 16. Capillary pressure curves for the rock rock matrix of nonwelded tuffs (Paintbrush and Calico Hills hydrogeologic units). The zeolitized tuffs are represented by a dotted line. matrix of welded tuffs (Tiva Canyon and Topopah Spring hydrogeologic units). The Tiva Canyon tuffs are represented by a dotted line.

\subsection{Fracture Properties}

A high fracture density has been reported in the literature for the welded units by Montazer and Wilson ${ }^{7}$, and previous modeling ${ }^{1,6}$ studies have emphasized their potentially large influence on gas and moisture flow. Fracture effects were added to the rock matrix characteristic curves for the Tiva Canyon and Topopah Spring hydrogeologic units through the equivalent continuum approximation developed by Klavetter and Peters ${ }^{14}$. This approximation, based on the assumption of capillary equilibrium between matrix and fractures, was applied to calculate the threshold saturation $S_{\text {th }}$ (Pruess et al. ${ }^{36}$ ) at which fracture flow begins:

$$
S_{t h}=\frac{\phi_{m}}{\phi_{m}+\phi_{f}}
$$

where:

$$
\begin{aligned}
& \phi_{\mathrm{f}}=\text { fracture porosity (assumed equal to } 0.001 \text { ) } \\
& \phi_{\mathrm{m}}=\text { matrix porosity }
\end{aligned}
$$


The approach used in the simulations assumes that the capillary pressure of the equivalent continuum is equal to that of the matrix until the threshold saturation is exceeded, then fracture flow, described here by a linear relationship between capillary pressure and saturation, dominates the matrix contribution to flow. Threshold saturations between 0.980 and 0.994 were obtained for the nine model sublayers representing the welded Tiva Canyon and Topopah Spring units. As no measured capillary functions have been reported in the literature for fracture medium, the approach used in the simulations is based on the assumption that the fracture has the same pore size distribution as the rock matrix for each rock type. The absolute fracture permeability was taken to be equal to $10^{-11} \mathrm{~m}^{2}$ based on values reported by Klavetter and Peters ${ }^{14}$. The air entry value is then predicted from the saturated permeability value $k_{\mathrm{s}}$ by using the scaling relationship proposed in Wang 38 :

$$
k_{s}=\left[\frac{2 \sigma \cos (\theta) \alpha}{\rho g}\right]^{2} / 8
$$

where:

$$
\begin{aligned}
& \sigma=\text { surface tension }=0.07183 \mathrm{~kg} \cdot \mathrm{s}^{-2} \\
& \theta=\text { contact angle }=0^{\circ} \\
& \alpha=\text { capillary scaling factor }=1 / \text { air entry value, } \mathrm{Pa}^{-1} \\
& \rho=\text { water density }=1000 \mathrm{~kg} \mathrm{~m}-3 \\
& g=\text { gravitational acceleration }=9.8 \mathrm{~m} \mathrm{~s}^{-2}
\end{aligned}
$$

The relative permeabilities were also scaled following the equivalent continuum approximation assuming that matrix and fracture flow follow the same functional form, and that their relative effect can be added above the threshold saturation value. The combined fracture and matrix characteristic curves developed here are shown in Figure 17 for the layers of the welded Tiva Canyon, and Topopah Spring units. These curves show that fracture dominated flow begins between 1000 and $3500 \mathrm{~Pa}$ for the various sublayers. The approach used therefore assumes that only matrix flow occurs until very high liquid saturations are reached.

\subsection{Fault Zone Properties}

The effect of fault zones had also been emphasized by previous studies ${ }^{2,4,6}$ to be important for the distribution of flow within Yucca Mountain. Within the three-dimensional grid, fault zones are represented by columns of gridblocks of about 200 to $350 \mathrm{~m}$ width. This large width is somewhat consistent with new field data about the lateral extent of the Ghost Dance fault reported by Spengler et al. ${ }^{30}$. In the present study, fault 
zones were assumed to behave as porous medium with either very high or very low permeability compared to the neighboring rock matrix. The van Genuchten model was used to calculate the capillary pressure curves shown in Figure 18, as well as the relative permeability curves of the fault zones for these two different test cases. The scaling parameter was calculated based on the assumed minimum and maximum saturated permeability $\left(10^{-20} \mathrm{~m}^{2}\right.$ and $10^{-11} \mathrm{~m}^{2}$ respectively) of the fault zones. The other fitting parameter $\mathrm{n}$ was chosen assuming that the pore size distribution of the fault zones is rather narrow $(n=2, m=0.5$ for high permeability fault, and $n=5, m=0.8$ for low permeability fault). Pore size distribution is comparatively broad for small values of $\mathbf{n}$ (such as 2), and becomes narrower as $\mathbf{n}$ becomes larger (such as 5). Larger values of $\mathrm{n}$ for the fault zones were found to give near-identical results but are more computationally intensive because pore size distribution becomes narrower as $n$ increases.

\section{NumERICAL SimulationS}

The integrated finite-difference computer code TOUGH2 developed by Pruess ${ }^{15}$ was used to simulate the steady-state moisture flow, the liquid sat-

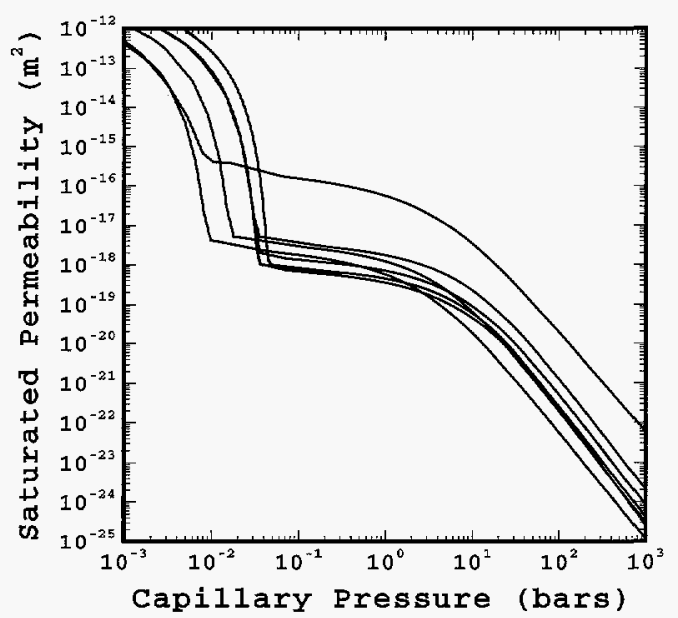

Figure 17. Combined fracture and matrix capillary pressure curves for the welded Tiva Canyon and Topopah Spring hydrogeologic units.

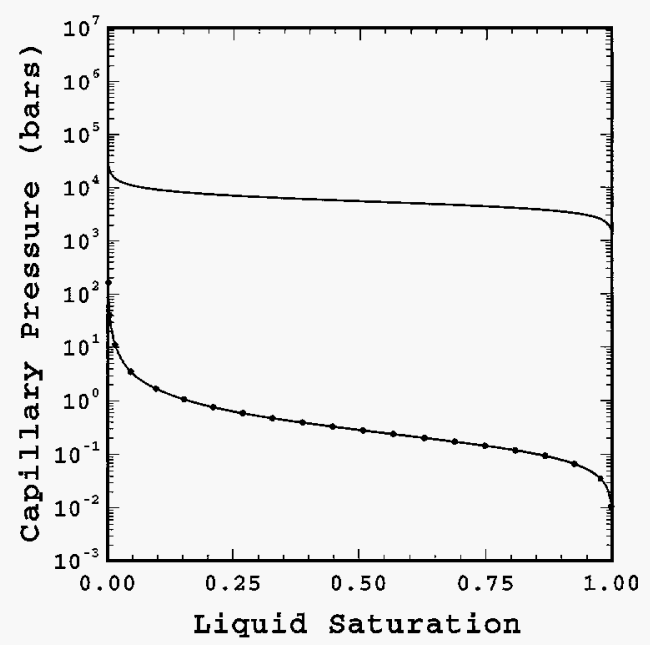

Figure 18. Capillary pressure curves for two types of fault zones. The low permeability fault is represented by a continuous line, and the high permeability fault by a dotted line. 
uration distribution and the capillary pressure distribution between land surface and the water table.

\subsection{One-Dimensional Simulations}

One-dimensional simulations were performed with a simplified dataset for rock properties and considered only matrix flow. Only five layers representing the main hydrogeologic units were considered in these simulations, which were conducted primarily to determine the sensitivity of the results to the number of vertical elements and their fineness, especially near unit boundaries. This small dataset given in Table 8 was based on measurements reported by Flint and Flint ${ }^{19}$, Nelson et al. ${ }^{39}$, and Rulon et al. ${ }^{1}$

Table 8. Simplified dataset of rock matrix properties used for onedimensional simulations.

\begin{tabular}{|c|c|c|c|c|c|}
\hline \multirow{2}{*}{$\begin{array}{c}\text { Hydrogeologic } \\
\text { Unit }\end{array}$} & \multirow{2}{*}{$\begin{array}{c}\text { Matrix } \\
\text { Porosity a,b } \\
(\%)\end{array}$} & \multirow{2}{*}{$\begin{array}{l}\text { Vertical Matrix }{ }^{a, c} \\
\text { Permeability }\left(m^{2}\right)\end{array}$} & \multicolumn{3}{|c|}{ van Genuchten Parameter } \\
\hline & & & $10^{-5}(\mathrm{~Pa})$ & $\mathbf{n}$ & $\mathbf{m}$ \\
\hline Tiva Canyon & 15 & $2 \times 10^{-19}$ & 1.147 & 3.04 & 0.671 \\
\hline Paintbrush & 30 & $10^{-14}$ & 3.645 & 2.25 & 0.555 \\
\hline Topopah Spring & 15 & $4 \times 10^{-19}$ & 1.147 & 3.04 & 0.671 \\
\hline Calico Hills - vitric & 30 & $5 \times 10^{-17}$ & 1.370 & 2.35 & 0.574 \\
\hline Calico Hills - zeolitic & 30 & $9 \times 10^{-19}$ & 1.370 & 2.35 & 0.574 \\
\hline
\end{tabular}

a: Flint and Flint $(1990)^{19}$

b: Nelson et al. (1991) ${ }^{39}$

c: Rulon et al. (1986) ${ }^{1}$

Infiltration rates of 0.1 and $1.0 \mathrm{~mm} / \mathrm{yr}$ were used to evaluate the effect of vertical grid refinement. Figure 19 shows an example of saturation profiles obtained for a $710 \mathrm{~m}$-thick section. An infiltration rate of $0.1 \mathrm{~mm} / \mathrm{yr}$ was used and the entire section was modeled using a coarse grid (19 blocks) and a fine grid (46 blocks) with $1 \mathrm{~m}$ thick gridblocks near the unit boundaries. These two simulations produced very similar results and indicated that the vertical grid consisting of about nineteen elements gives sufficiently accurate results.

\subsection{Two-Dimensional Simulations}

Steady-state two-dimensional numerical simulations were performed to evaluate the occurrence and magnitude of lateral flow within the various blocks delineated by major faults, and to evaluate the formation of perched- 


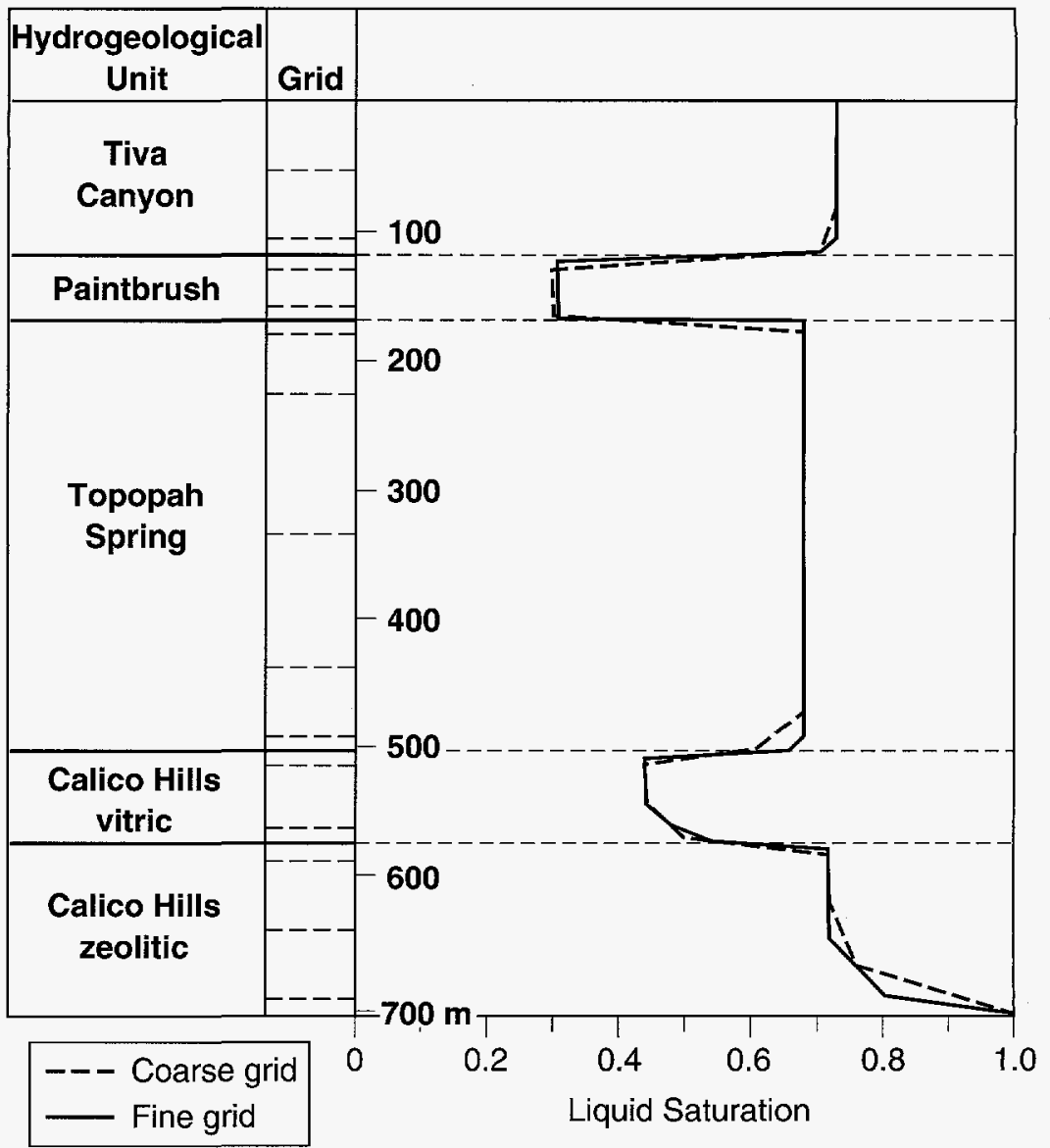

Figure 19. Liquid-saturation profiles for a schematic vertical column of 19 and 46 gridblocks (infiltration rate $0.1 \mathrm{~mm} / \mathrm{yr}$ )

water bodies at the lithologic and structural boundaries between difterent hydrogeologic units. The influence of fault zones and the infiltration distribution on the liquid-water flow through the potential repository unit and to the water table was also evaluated for various cases.

Numerical simulations were performed using two NW to SE two-dimensional cross-sections extracted from the three-dimensional grid. In order to be able to compare the moisture distribution within blocks of rocks bounded by only one or two fault zones, the locations of the profiles shown in Figure 20 were chosen. The middle cross-section (A-A') cuts the site-scale model area at the level of the potential repository, and includes Ghost Dance 
fault. A second cross-section (B-B') is located about $3 \mathrm{~km}$ further to the south, and intersects the Abandoned Wash- and Dune Wash faults.
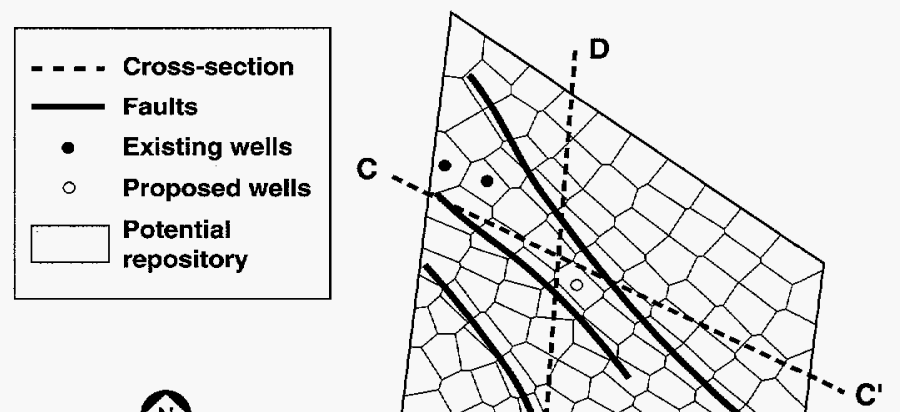

N)
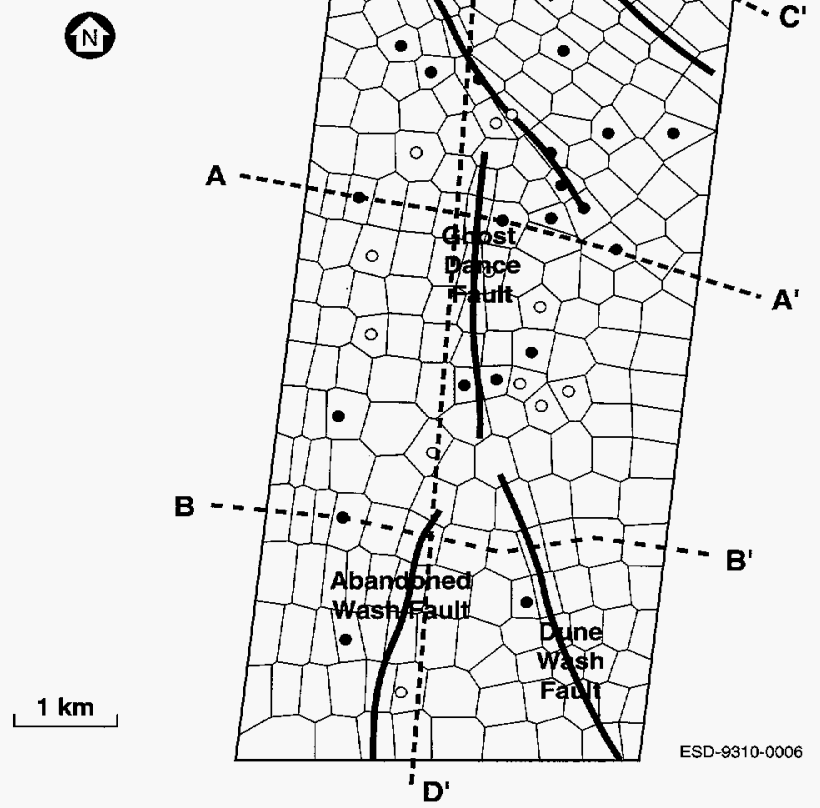

Figure 20. Horizontal grid for the site-scale model showing the cross-sections used in the simulations $\left(A-A^{\prime}\right.$ and $\left.B^{-} B^{\prime}\right)$ and for displaying 3-D simulation results $\left(C-C^{\prime}\right.$ and $\left.D_{-1} D^{\prime}\right)$.

The vertical grid for both cross-sections is given in Figure 21, together with the names of boreholes which are located at the center node of four gridblock columns.

Capillary and saturation distributions for two vertical cross-sections were calculated for three spatially uniform infiltration rates of $10^{-1}$ to $10^{-3}$ $\mathrm{mm} / \mathrm{yr}$ using rock matrix-, fracture-, and fault properties described above in Chapter 5 . 
a.

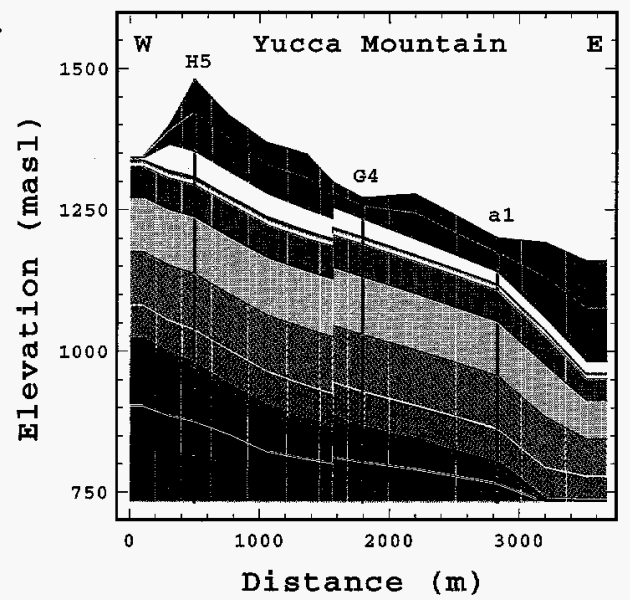

b.

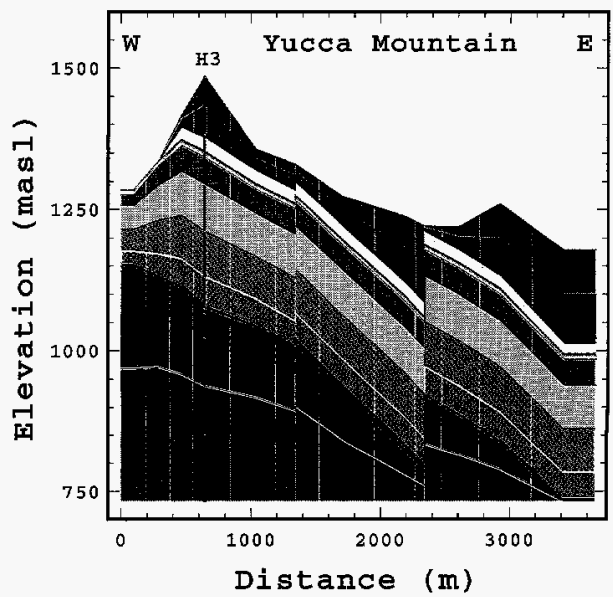

Figure 21. Schematic of vertical cross-sections (a) A-A'; and (b) B-B' showing fault offsets and model sublayer thickness variations.

Simulation results discussed in the following sections are grouped according to assumptions made about the hydrologic character of the fault zone.

\subsubsection{High permeability fault zone}

Examples of results are shown for the set of simulations using the maximum infiltration rate of $10^{-1} \mathrm{~mm} / \mathrm{yr}$ in Figure 22 for capillary pressure, and in Figure 23 for liquid saturation. The capillary pressure values were consistently above -10 bars in all layers, except near the western boundary of the cross-section where a low capillary pressure zone ( -22 bars) occurred near the top layers of the Calico Hills hydrogeologic unit. This low capillary pressure zone was probably due to decreased vertical flow caused by increased lateral flow in the upper layers of the Topopah Spring unit. The capillary pressure decreased in the Tiva Canyon unit, down to the middle of the Topopah Spring Unit, where the pressure reached -2 bars due to the high saturation of a low permeable layer (sublayer representing the upper lithophysae zone).

As can be seen on Figure 23, the low liquid saturation (0.03) in the fault zones was a predominant feature of these simulations, and was due to the characteristic curves that were chosen. The liquid saturations of the different hydrogeologic units varied within well defined limits, such as 0.92-0.97 in the Tiva Canyon, $0.50-0.61$ in the Paintbrush, 0.86-0.92 in the Topopah Spring, $0.60-0.70$ in the Calico vitric, and $0.94-0.98$ in the Calico zeolitic sublayers. This saturation distribution also showed distinct trends. First, the liq- 


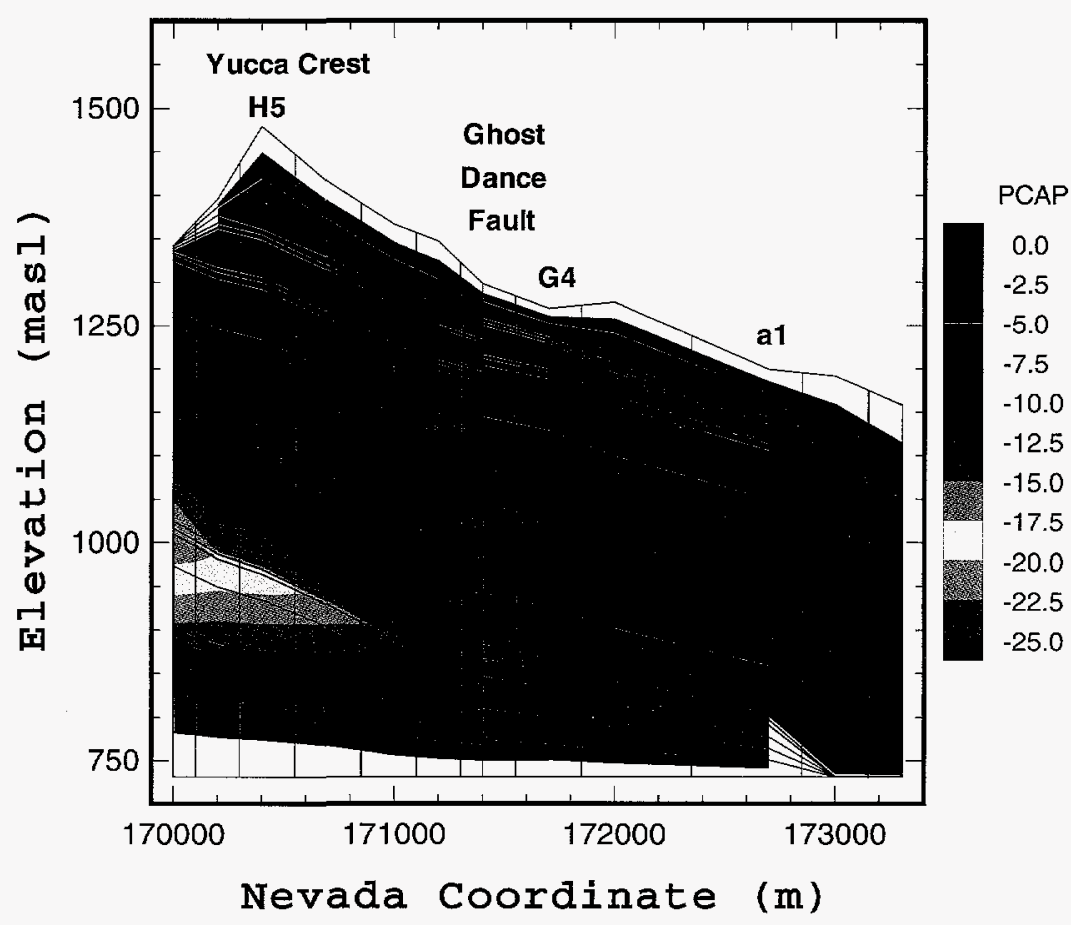

Figure 22. Capillary pressure distribution for cross-section A-A' with infiltration rate of $10^{-1} \mathrm{~mm} / \mathrm{yr}$, and a saturated permeability of $10^{-11}$ $\mathrm{m}^{2}$ for Ghost Dance fault.

uid saturation in the Tiva Canyon unit decreased with depth. A high saturation zone (0.98) occurred at the bottom of the Topopah Spring unit just above the water table in the eastern part of the model, and propagated westward at the contact with the Calico Hills vitric layers slightly further than Ghost Dance fault.

Another set of simulations were performed with a decreased infiltration rate of $10^{-2} \mathrm{~mm} / \mathrm{yr}$. In this case, the capillary pressure increased uniformly from about -20 bars near the ground surface to zero at the water table, except near the western boundary where the low capillary pressure zone of -28 bars was found in the lower part of the Topopah Spring unit. The capillary pressure in the fault zone was again uniform, but had decreased to -10 bars. The saturation distribution was similar to the previous simulations, but the liquid saturations had decreased to $0.84-0.80$ in the Tiva Canyon, to $0.40-0.53$ in the Paintbrush, and to $0.65-0.90$ in the Topopah Spring hydrogeologic unit.

Numerical simulations were also run to reach steady-state with an infiltration rate of $10^{-3} \mathrm{~mm} / \mathrm{yr}$. The capillary pressure distribution obtained for 


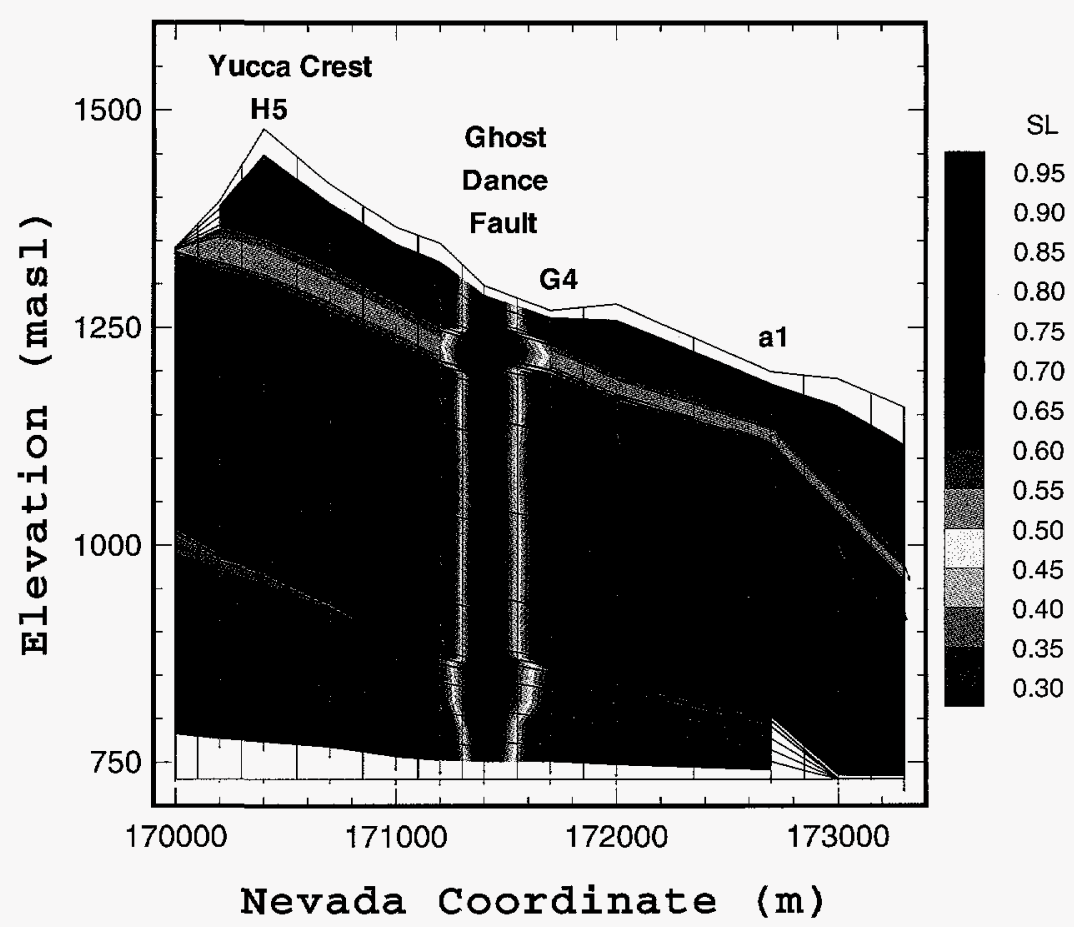

Figure 23. Liquid saturation distribution for cross-section $\mathrm{A}-\mathrm{A}^{\prime}$ with infiltration rate of $10^{-1} \mathrm{~mm} / \mathrm{yr}$, and a saturated permeability of $10^{-11}$ $\mathrm{m}^{2}$ for the Ghost Dance fault.

this very low rate did not deviate strongly from static conditions, with the capillary pressure near the ground surface decreasing to -70 and -50 bars, depending on the elevation from -40 and -30 bars, respectively for the $10^{-2}$ $\mathrm{mm} / \mathrm{yr}$ case. The capillary pressure in the fault zone stayed uniformly around -17 bars, and increased close to the water table. The liquid saturations in the three upper units also decreased further to 0.77-0.67 in the Tiva Canyon, $0.35-0.45$ in the Paintbrush, and $0.60-0.85$ in theTopopah Spring hydrogeologic unit.

\subsubsection{Low permeability fault zone}

Except within the Ghost Dance fault zone itself, the overall capillary pressure and liquid saturation distributions obtained for these simulations with a low permeability fault zone were similar to those described above for the high permeability fault. In the case of $10^{-1} \mathrm{~mm} / \mathrm{yr}$ infiltration rate, the main difference was that the capillary pressure in the middle of the Topopah Spring hydrogeologic unit reached -2 bars, and even -1 bars in the fault zone 
at the same elevation. Contrary to the simulations with high permeability fault zones, very high liquid saturations were found in the fault zone because of the assumed characteristic curves.

\subsubsection{Effect of two fault zones (simulations with cross- section B-B')}

Two fault zones (Abandoned Wash fault and Dune Wash fault) were intersected by cross-section B-B'. Except for a few details, the distributions in the capillary pressure and saturation, using high and low permeability fault zones did not differ significantly from the equivalent cases including only Ghost Dance fault. The main difference concerned the location and the intensity of the low capillary pressure zone located at the boundary between the Topopah Spring and the Calico Hills hydrogeologic units. The results for the simulations with the $10^{-2} \mathrm{~mm} / \mathrm{yr}$ infiltration rate given in Figure 24 for capillary pressure, and in Figure 25 for liquid saturation, showed that this low capillary pressure zone ( -36 bars) was centered at the top of Calico Hills hydrogeologic unit. A similar low capillary pressure zone ( -20 bars) occurred in the block between the two faults, but was located in the lower part of the Topopah Spring unit. For the $10^{-1} \mathrm{~mm} / \mathrm{yr}$ infiltration rate, the low capillary pressure zone ( -25 bars), again centered near the top of the Calico Hills unit, had moved eastward to the third gridblock, just below Yucca Mountain crest. The liquid saturation distribution presented in Figure 25 also illustrated the dominant influence of the fault zones.

\subsubsection{Vertical and lateral flow, perched water}

The occurrence and intensity of lateral flow was studied by normalizing the vertical moisture flow between sublayers by the constant infiltration rate imposed at the ground surface (normalized vertical flow $=V$ ). Lateral flow occurred when vertical flow was diverted because of the tilting of the layers, and it may have been enhanced by the permeability contrast. In our simulations, this lateral eastward flow was terminated by the fault zones, because of their assumed flow characteristics. The dependence of lateral flow intensity on the tilting of the sublayers was evident because the cross-sections included several blocks with increasing slopes. Whereas vertical flow was generally dominant throughout most of the model domain, lateral flow was often apparent in the upper part of the Topopah Spring hydrogeologic unit (the sublayer representing the rounded zone) above the upper lithophysae zone. Weaker lateral flow also occurred in the first sublayer of the Paintbrush unit, just below the very low permeability vitrophyre sublayer of the Tiva Canyon unit. Because the magnitude of lateral flow depended on catchment area, the calculated flows on the western side of Abandoned Wash-, and Dune Wash faults were smaller than those defined at Ghost Dance fault. 
Figure 24. Capillary pressure distribution for crosssection B-B' with infiltration rate of $10^{-2} \mathrm{~mm} / \mathrm{yr}$, and a saturated permeability of $10^{-20}$ $\mathrm{m}^{2}$ for Abandoned Wash and Dune Wash faults.

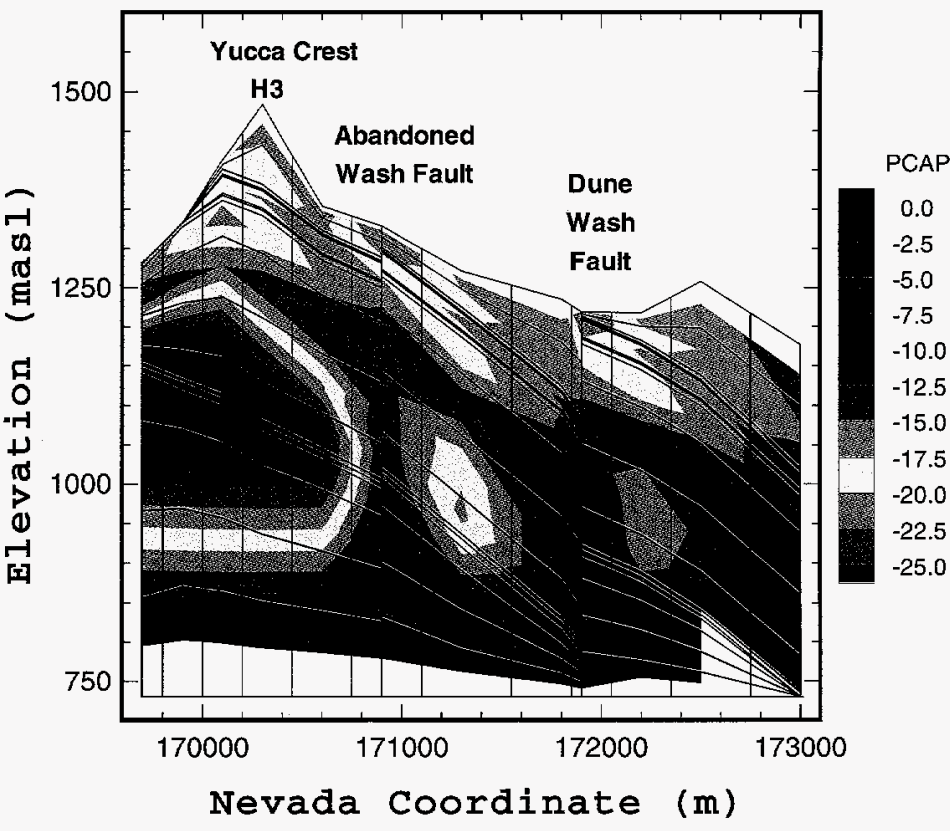

Figure 25. Liquid saturation distribution for cross-section B-B' with infiltration rate of $10^{-2} \mathrm{~mm} / \mathrm{yr}$, and a saturated permeability of $10^{-20} \mathrm{~m}^{2}$ for the Abandoned Wash and Dune Wash faults

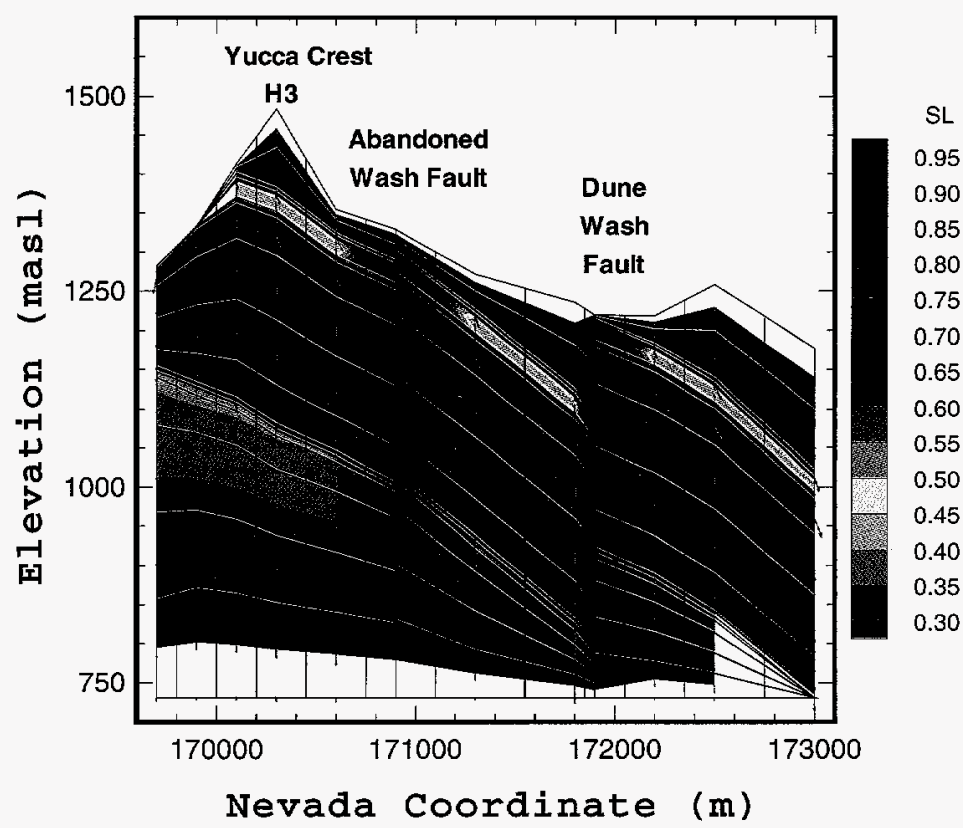


The normalized vertical flow through the Topopah Spring unit increased from about 0.6 near the Solitario Canyon fault to 1.6 near the Ghost Dance fault as a result of lateral flow within the overlying units.

Outside of the fault zones, moisture flux within the Topopah Spring hydrogeologic unit was predominantly vertical. Lateral flow components were minor compared with vertical flow, even within the very low permeability vitrophyre layers. A small westward lateral flow component was present on the eastern side of Yucca Mountain for cross-section B-B', possibly due to grid effects.

Vertical flow rates were also studied within the Ghost Dance fault zone. The vertical normalized flow rate $\mathrm{V}$ through the high permeable fault zone varied from about 1.0 near the ground surface for high infiltration rates to very small values above the water table for low infiltration rates. A general feature showed a strong decrease in vertical flow rate $V$ with depth in the fault zone, suggesting that water flowed into the adjacent formation. This phenomenon mainly happened for lower infiltration rates ( $V$ down to 0.05 ), and was reduced $(\mathrm{V}=0.9)$ at higher infiltration rate $\left(\mathrm{I}=10^{-1} \mathrm{~mm} / \mathrm{yr}\right)$. This effect seemed to be limited to the gridblocks close to the fault zone. Our results suggested that this lateral flow out of the fault zone might happen not only in the Paintbrush and top of Topopah Spring hydrogeologic units, but also between the middle part of the Topopah Spring unit and the water table. The reason for this outflow from the fault zone was again the characteristic curves used. High flow within the fault zone results in relatively high capillary pressures, hence the moisture evaded the fault zone for the lower (more negative) capillary pressure surrounding rocks.

None of the simulations predicted the occurrence of perched water zones, possibly due to the relatively low infiltration rates used. However, even at these low flow rates, nearly saturated zones were predicted to form at the base of the Topopah Spring hydrogeologic unit, especially east of Ghost Dance fault.

\subsection{Three-Dimensional Simulations}

We have conducted a series of three-dimensional moisture flow simulations in order to investigate possible patterns of moisture flow within Yucca Mountain. The approach used is to assume a given average infiltration rate, then assume an infiltration distribution (either uniform or spatially variable) and finally use the three-dimensional site-scale model to compute the moisture flow within the mountain, for assumed hydrological characteristics of the major faults. All of these assumptions have to be made in the current work, because of the uncertainties associated with the various model input 
parameters, such as the effective infiltration rates and distributions, hydrological fault property values, and hydrogeologic parameters.

\subsubsection{Uniform infiltration rate}

A series of simulations were conducted using the three-dimensional site-scale model assuming an areally uniform infiltration rate. Different average uniform infiltration rates ranging from 0.001 to $0.5 \mathrm{~mm} / \mathrm{yr}$ were considered. In these simulations the faults were modeled assuming either with "capillary barrier" behavior or "permeable fault" behavior.

In general, it is difficult to show a complex three-dimensional distribution of saturation, capillary pressures or fluid flow. Figure 26 is an attempt to show one example of calculated three-dimensional liquid saturation within Yucca Mountain using data from four different cross-sections. The cross-sections used in generating Figure 26 are A-A', B-B', C-C' and D-D', located as shown in Figure 20. Figure 26 shows the obvious features of the model results including the low saturation conditions in the faults and the hydrogeologic units, as well as the complex stratigraphic effects on the saturation distribution. It is not possible, however, to show with this representation the detailed effects of the stratigraphic sublayers, on moisture flow, or saturation conditions within the mountain. It should be noted that the bottom boundary in Figure 26 represents the water table.

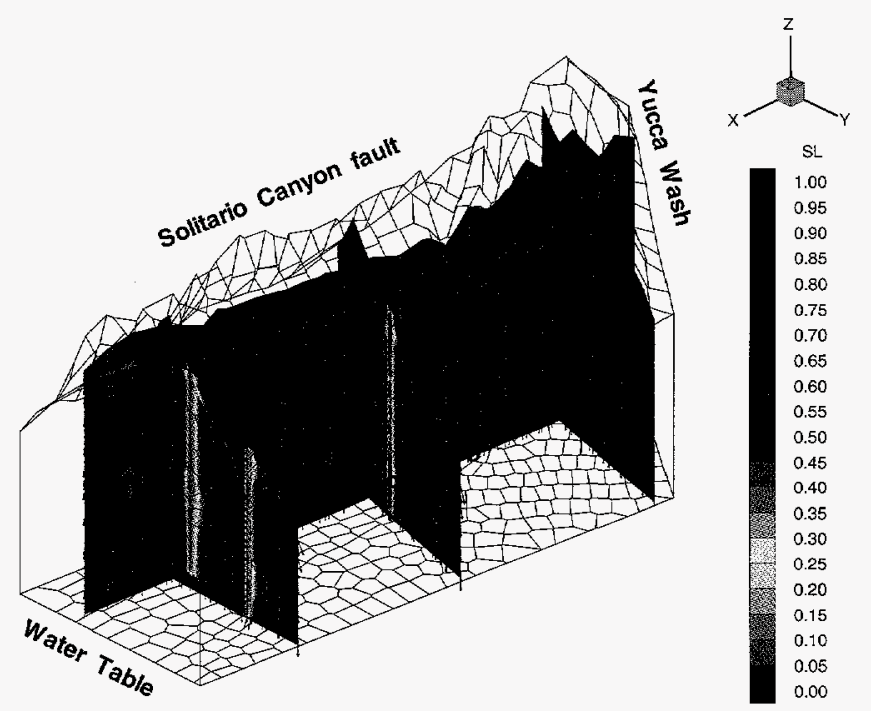

Figure 26. A quasi-three-dimensional calculated liquid saturation at Yucca Mountain shown using data for cross sections A-A', B-B', C-C' and D-D' (see Figure 20). 
One of the important objectives of the current study is to investigate where in Yucca Mountain does near vertical one-dimensional flow dominate, and where does somewhat more complex two-dimensional moisture flow occur, and finally, where the most complex three-dimensional flow regime is expected. This type of information is of utmost importance when decisions have to be made regarding locations of holes for surface-based testing and locations of tunnels and drifts for subsurface tests and analysis. It is certainly not cost effective to place additional boreholes in regions where sufficient understanding of flows and rock properties is already achieved because of the relatively simple one-dimensional moisture flow field that occurs in that region.

Figure 27 shows four nearly horizontal sections of normalized vertical moisture flow within the mountain. Here we define the normalized vertical moisture flow as the vertical moisture flow at any location $(x, y, z)$ normalized (divided by) the assumed average infiltration rate at the ground surface (in this case, $0.1 \mathrm{~mm} / \mathrm{yr}$ ). These horizontal sections are shown for locations above and below the Paintbrush nonwelded hydrogeologic unit (bottom of welded Tiva Canyon unit; top of Topopah Spring), at the bottom of the Topopah Spring hydrogeologic unit, and at the water table. Figure 27a shows that the moisture flow in the Tiva Canyon unit is near vertical with almost no variation in normalized vertical flux (everywhere about $100 \%$ of the net infiltration-rate at the ground surface). Figure $27 \mathrm{~b}$, which represents a location below the Paintbrush unit, shows a large degree of variation due to lateral flow within that unit when compared to Figure $27 \mathrm{a}$. In general, lateral flow occurs towards the east due to the dipping of the layers, with moisture accumulation close to major faults (assumed to be capillary barriers in this case) and model boundaries (e.g., the Bow Ridge fault is assumed to be an impermeable boundary in the model). In the horizontal section representing the bottom of the Topopah Spring unit (Figure 27c), additional lateral flow is evident with drying of regions east of major faults and moisture accumulation directly west of the faults. This trend is further enhanced at the water table (Figure 27d).

Several important conclusions can be drawn from these results keeping in mind the underlying assumptions of uniform infiltration of $0.1 \mathrm{~mm} / \mathrm{yr}$ and faults acting as "capillary barriers":

(1) Most of the lateral moisture flow occurs in the Paintbrush nonwelded units;

(2) There is considerably more lateral flow in the southern part of Yucca Mountain than the northern part, primarily because of steeper dipping layers in the southern part. In some regions north of Ghost Dance 

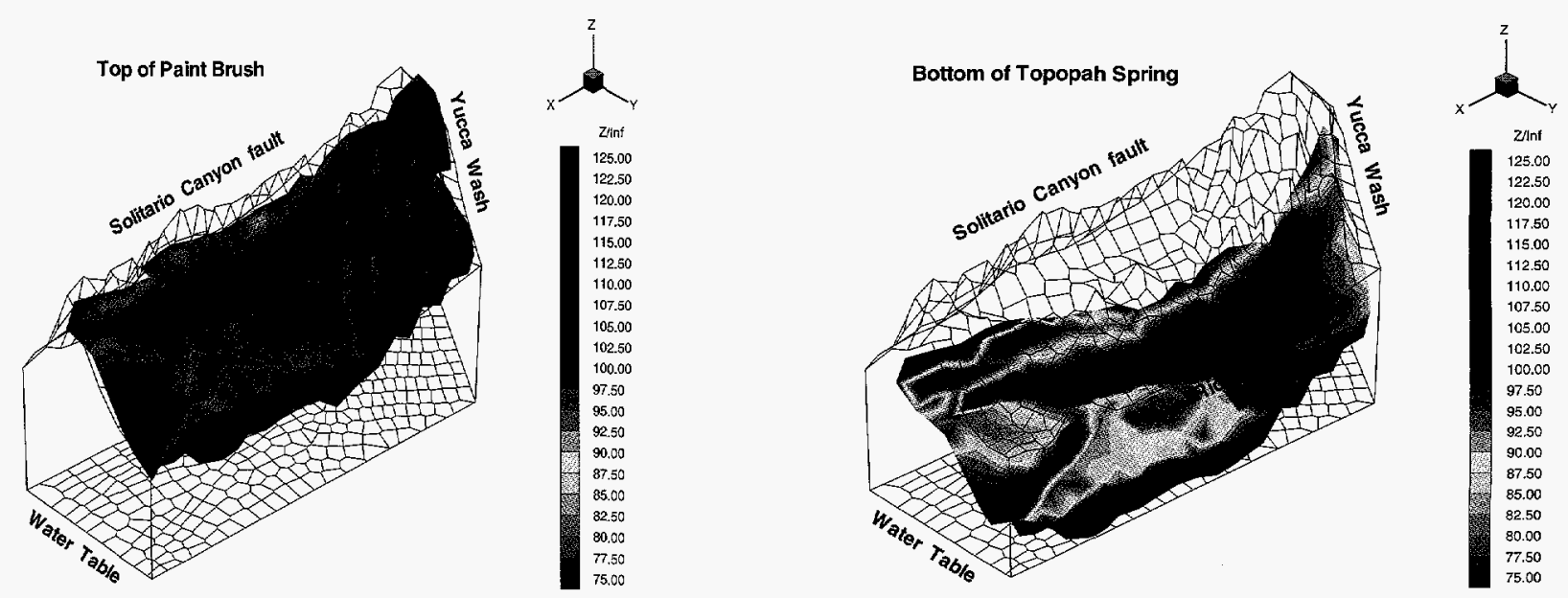

a.
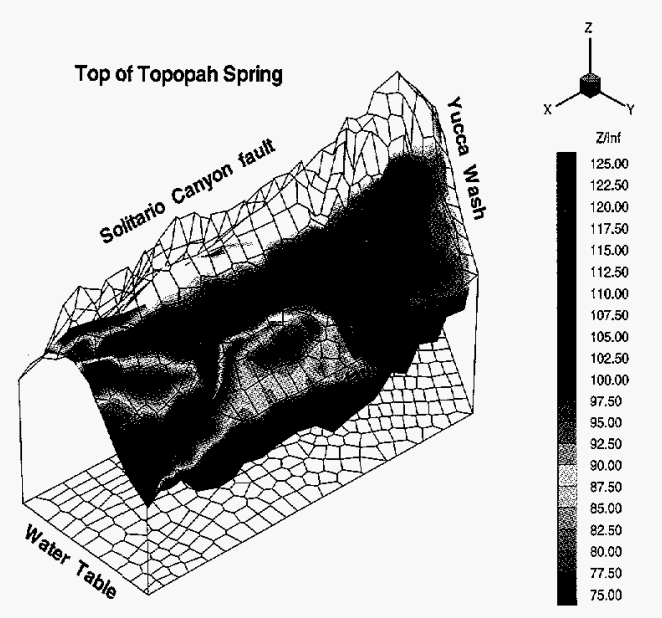

c.

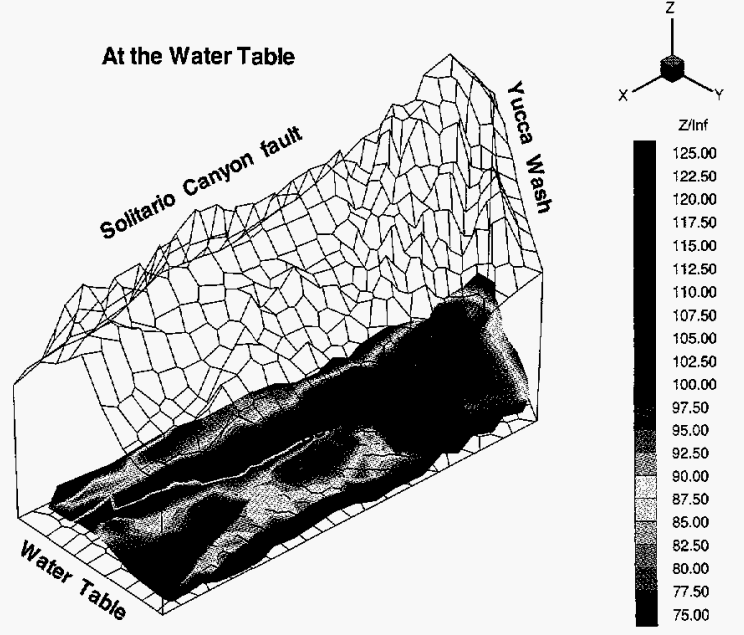

b.

Figure 27. Calculated normalized vertical moisture fluxes (\% of infiltration at ground surface) at different depths in the site-scale model for the case of "capillary barrier" faults, and a uniform areal infiltration rate of $0.1 \mathrm{~mm} / \mathrm{yr}$.

fault near one-dimensional vertical moisture flow is exhibited from these model calculations.

(3) Large vertical flow is found directly west of major faults due to lateral flow and moisture accumulation near the faults because of their "capillary barrier" nature in these simulations. Hence, measurements of 
saturations and capillary pressures in rock matrix blocks near faults may be useful for inferring the flow characteristics of the faults.

Figures 28a through $28 \mathrm{~d}$ show similar horizontal sections for the case of a "permeable fault" (uniform infiltration rate of $0.1 \mathrm{~mm} / \mathrm{yr}$ ). Figure 28a shows that for most of the mountain the moisture flow within the Tiva Canyon unit will be near-vertical except for some lateral infiltration into the major faults and subsequent vertical drainage. Again, the large lateral flow potential of the nonwelded hydrogeologic units is evident when Figures 28a and $28 \mathrm{~b}$ are compared. In this case the major faults clearly establish themselves as major vertical pathways for flow. Similar conclusions can be reached about subsequent deeper horizontal sections as greater portions of the vertical flow occur through the major faults. It is interesting to note that again some of the area north of the Ghost Dance fault exhibits very little evidence of lateral flow with near uniform vertical flow in this area. The major faults in the northern part of the model region (Sever Wash, Pagany Wash and Teacup Wash faults) are strike-slip faults with small offsets based on cross-sections given in Scott and Bonk $k^{9}$. One should note that although the vertical moisture migration far from the three faults that are modeled discretely is near-uniform for this case, these results are dependent on the assumption that infiltration is uniformly distributed and that the strike-slip faults in the northern part of Yucca Mountain are hydrologically indistinguishable from the surrounding country rocks.

\subsubsection{Non-uniform infiltration}

A numerical simulation was also performed assuming non-uniform distribution of infiltration at the ground surface.The results are shown in Figure $29 \mathrm{a}$ through $29 \mathrm{~d}$. In this case, the major washes in the northern part of the mountain are assumed to accept the bulk of the infiltration, with additional infiltration in the washes located in the south-eastern part of the model. The calculated areally averaged infiltration rate for the non-uniform pattern is about $0.1 \mathrm{~mm} / \mathrm{yr}$. Figure 29a shows basically the areas where the concentrated infiltration occurs; zero net infiltration is assumed elsewhere. Figures 29a through $29 \mathrm{~d}$ show how the relatively concentrated infiltration flux is dispersed laterally as well as vertically. Observations of moisture migration close to the water table show that it is nearly uniform over areas of several square kilometers, although the concentrated flux was in regions with characteristic lengths of only a few hundreds of meters. Some of this may be due to grid effects. A similar infiltration pattern but with a higher areally-averaged infiltration rate is given by Flint and Flint (1994) ${ }^{22}$. Current work on non-uniform infiltration studies involves investigating cases with this new infiltration pattern. 


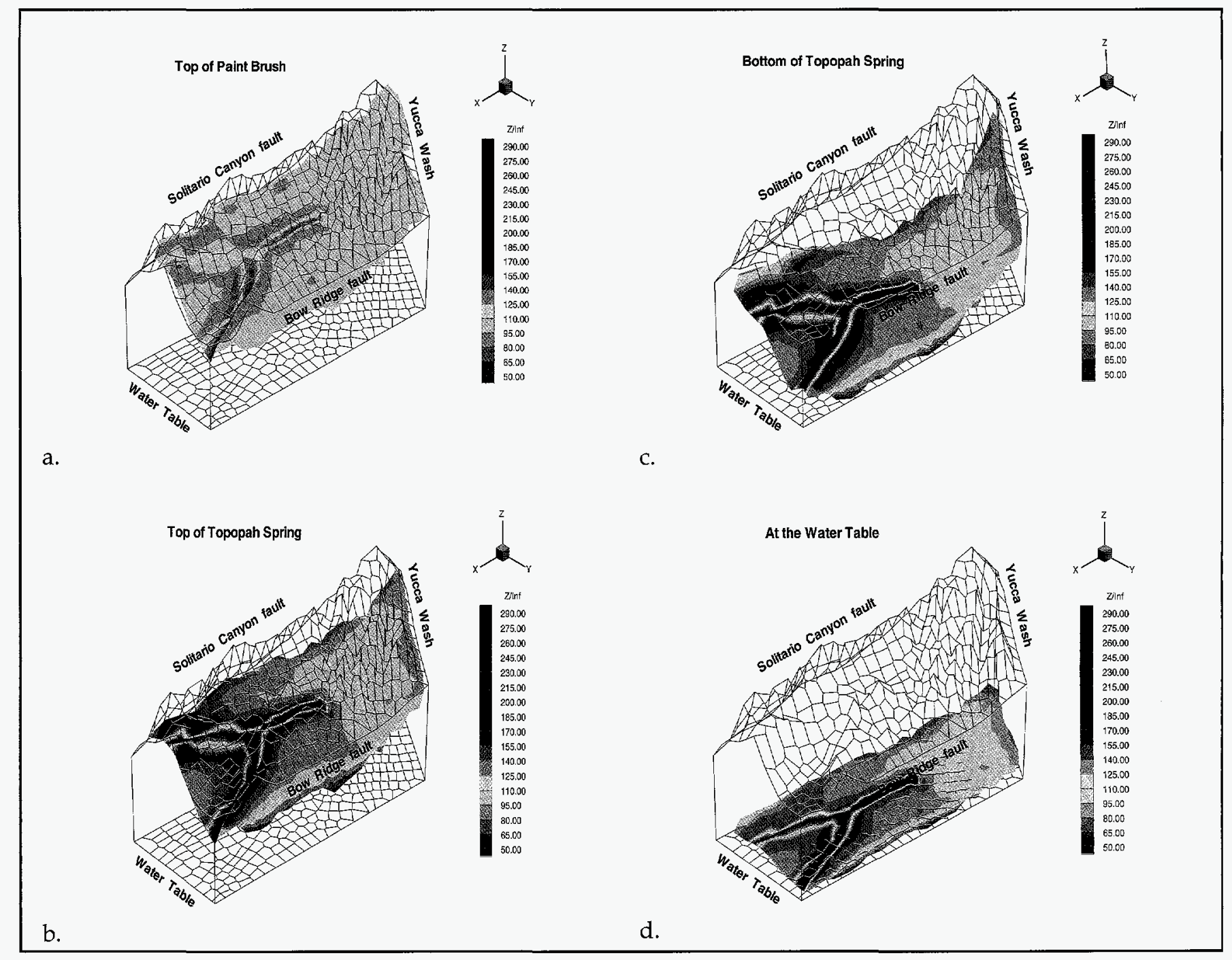

Figure 28. Calculated normalized vertical moisture fluxes (\% of infiltration at ground surface) at different hydrogeologic unit boundaries in the sitescale model for the case of "permeable" faults, and a uniform areal infiltration rate of $0.1 \mathrm{~mm} / \mathrm{yr}$. 


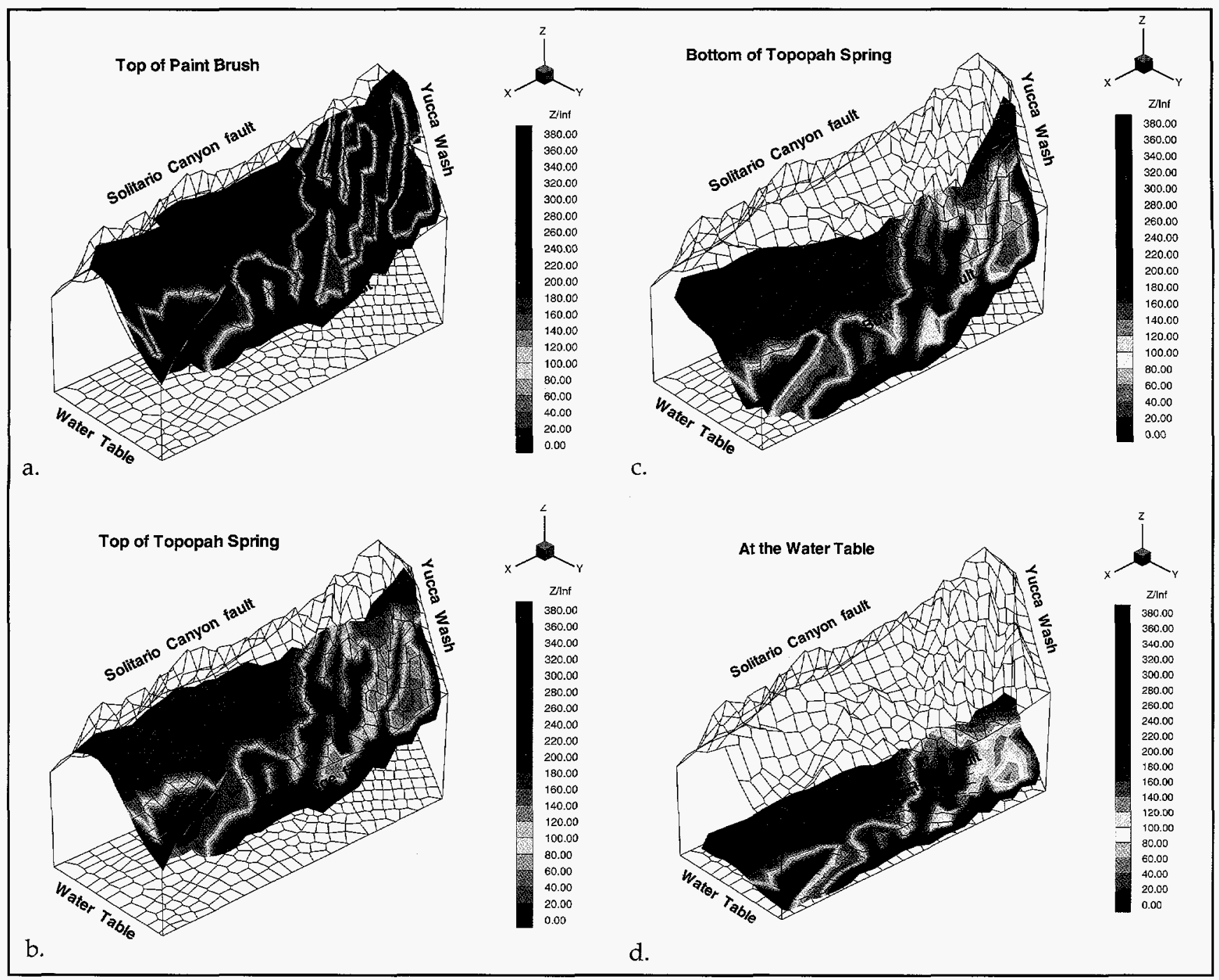

Figure 29. Calculated normalized vertical moisture fluxes (\% of average net infiltration) at different hydrogeologic unit boundaries in the site-scale model for the case of "capillary barrier" faults, and non-uniform infiltration (average $0.1 \mathrm{~mm} / \mathrm{yr}$ ). 


\section{Model PREdictions}

The quality and accuracy of complex three-dimensional models such as the site-scale model can only be tested and verified by model predictions, and later comparisons with observed field data. We have started this process for boreholes UE-25 UZ\#16 and USW UZ-14. In the case of borehole UZ\#16, we made predictions of liquid saturation and capillary pressure profiles versus elevation. Figure 30 presents the results of these predictions. In general, the predictions were reasonable compared to the subsequently measured saturation profile, but significant differences were found in both the Topopah Spring and the Calico Hills units. The major discrepancy was due to differences in locations of predicted geological units and those found during drilling, especially in the Calico Hills with the vitric and zeolitic units. The model predictions also indicated high liquid saturations $(>80 \%)$ in the entire Topopah Spring unit, whereas the measured values show a gradual increase in liquid saturation below the bedded (Paintbrush) units from about 50 to $80 \%$ over a depth interval of about $125 \mathrm{~m}$. The best comparison between the observed and predicted liquid saturation profiles for UZ \#16 was obtained when a uniform infiltration rate of about $0.1 \mathrm{~mm} / \mathrm{yr}$ was assumed. We are currently calibrating the three-dimensional site-scale model to match accurately the observed conditions in UZ\#16, and also predicting liquid saturation profiles for borehole UZ-14.

Other predictions by the 3-D unsaturated zone model of phenomena observed at Yucca Mountain will include the age and distribution of perched water. The presence of perched water in some of the more recently drilled boreholes (USW UZ-1, USW UZ-14, USW NRG-7/7A, and USW SD-9, reported by Burger and Scofield ${ }^{40}$ ) indicates that there may be significant gravity-driven fracture and/or fault flow with minimal interaction with the matrix ('fast pathways'). Water samples from the Calico Hills nonwelded hydrogeological unit in borehole UE-25-UZ\#16 have been concluded to be of younger age than samples from the overlying Topopah Springs welded unit through isotopic analyses (Fabryka-Martin et al. ${ }^{41}$ ). Additionally, an elevated ${ }^{36} \mathrm{Cl}$ signal at the base of the alluvium in UZ \#16 may indicate lateral flow along the alluvial/ Tiva Canyon welded hydrogeological unit contact fed by infiltration along sideslopes. This mechanism may contribute to saturations in the alluvium high enough to initiate fracture flow. Other subsurface features within Yucca Mountain that could contribute to the initiation of fracture flow in the underlying units include (Gauthier et al. ${ }^{42}$ ) buried geological features such as paleowashes, undulations in nonwelded geologic units causing water to pool, and lateral diversion of flow due to dipping units or permeability contrasts leading to locally saturated conditions. Fracture flow is sustained when the exchange of water between the fracture and the sur- 


\section{Borehole UZ16 Predictions}
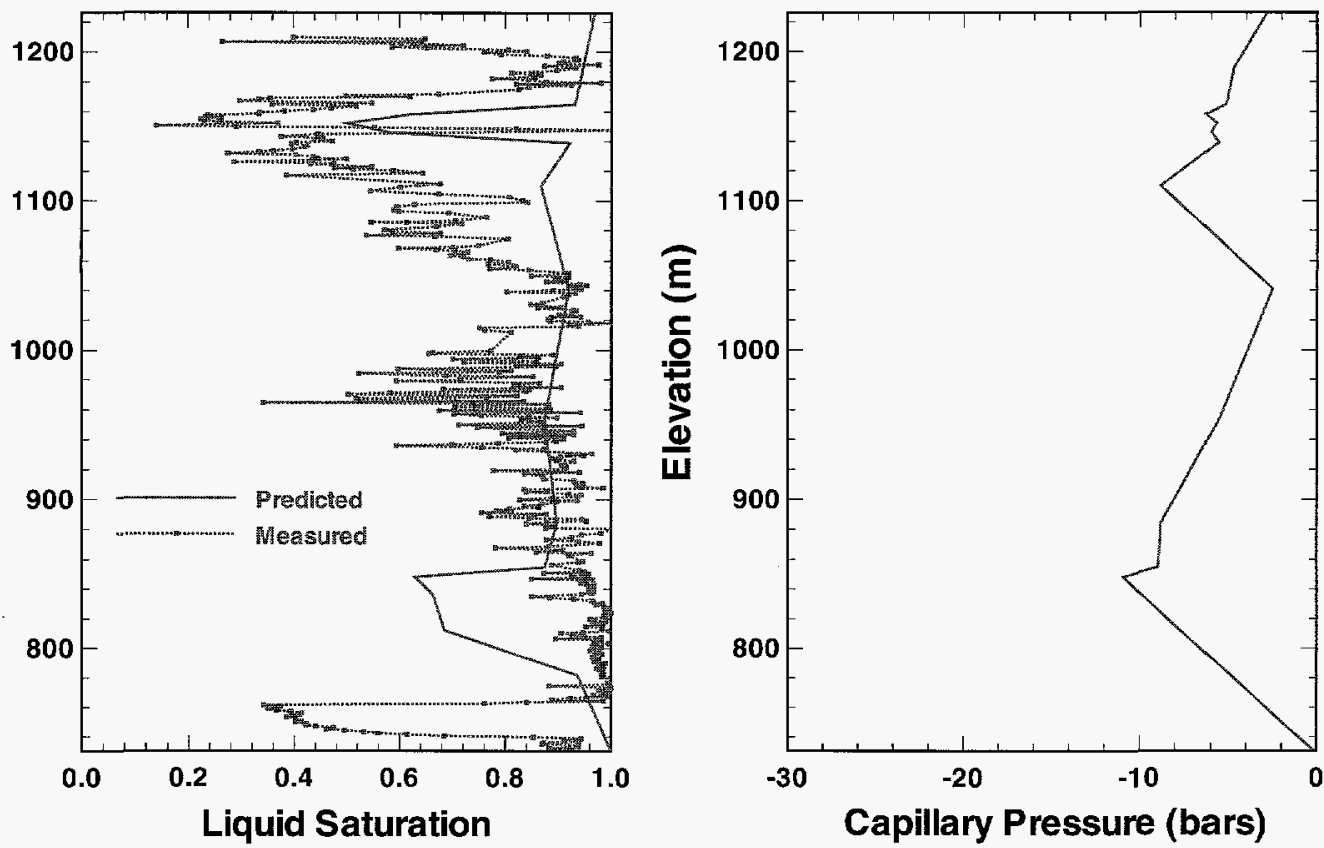

Figure 30. Borehole UE-25 UZ\#16 modeling predictions for saturation and capillary pressure versus elevation above mean sea level for a uniform infiltration rate of $0.1 \mathrm{~mm} / \mathrm{yr}$.

rounding matrix is limited due to flow occurring in pulses, low permeabilities in the matrix, or coatings on the fracture walls.

Due to the equivalent continuum assumption presently used as discussed in the Fracture Properties Section, the model, as it is configured for the simulations discussed in this report, does not consider nonequilibrium flow. Nor does it consider the presence of certain types of fast pathways, such as those that may result from focusing of flow due to heterogeneities in the rock matrix properties. However, the model does include the presence of faults which can serve as fast pathways. The equivalent continuum assumption does not lead to significant fracture flow until saturations in the surrounding matrix are greater than $98 \%$. This situation rarely occurs with the infiltration rates discussed in this report. Additionally, the use of long-term average recharge rates may obscure the potential for short-duration, high-intensity flow events to occur in fractures. These events, not considered in the present formulation of the model, may have resulted in the deep penetration of environmental tracers such as the ${ }^{36} \mathrm{Cl}$ recently noted at $\mathrm{UZ \# 16.} \mathrm{Another}$ potential difficulty of using present-day infiltration rates in the modeling is 
that the saturation and water potential distribution at depth may reflect boundary conditions as they existed at some time in the distant past during a potentially wetter period.

Potential approaches to model predictions of fast pathways and perched water include replacing the equivalent continuum assumption with the dual-porosity/permeability formulation which will lead to significant fracture flow prior to fully saturated conditions in the surrounding matrix. Additional work on infiltration patterns by Flint and Flint $t^{22}$ with a reported non-uniform areally-averaged rate of greater than $1 \mathrm{~mm} / \mathrm{yr}$ has been incorporated into present 3-D model simulations, leading to higher saturations in the model sublayers. Additional data on present and historic infiltration patterns and rates will be used as they are available.

\section{Concluding Remarks}

Lawrence Berkeley Laboratory, in collaboration with the USGS, has developed a three-dimensional numerical model for the unsaturated zone at Yucca Mountain. The current report focuses on the design of the vertical and horizontal grid systems, which will form the framework for subsequent simulations. The nodal distribution in the model was based on the locations and distribution of existing and proposed boreholes, varying infiltration characteristics, hydrogeologic units, major faults, and water-level data. Nodal points in plan view were located to allow direct comparison of model results and field data, to explicitly describe fault properties, and to accurately depict the aerial distribution of infiltration zones. These infiltration zones were divided into uncovered ridgetops, talus-covered sideslopes, and alluvial-filled washes. The numerical grid was aligned along surface traces of high-angle faults, such as the Ghost Dance-, Abandoned Wash-, and Dune Wash faults, and along northwest-trending strike-slip features, to facilitate inclusion of fault-zone properties as more data become available during characterization efforts. The vertical grid composed of seventeen sublayers accommodated variability in the properties of hydrogeologic units. Fine elements were used near boundaries of hydrogeologic units where abrupt thermodynamic gradients, lateral flow, and zones of perched water were likely to occur.

Major hydrogeologic units within the unsaturated zone throughout the site-scale model area included, in descending order, the Tiva Canyon welded unit, Paintbrush nonwelded unit, Topopah Spring welded unit, and the Calico Hills nonwelded unit. Their spatial distribution was defined by studying available surficial and borehole data, and developing isopach maps, or contour maps of their boundaries. The Tiva Canyon welded hydrogeologic unit crops out over most of the model area and dips to the east by $5^{\circ}$ to about $30^{\circ}$, except in the northern part of the area where the unit dips southeastward. 
The Paintbrush nonwelded hydrogeologic unit ranges in thickness from about $25 \mathrm{~m}$ to $170 \mathrm{~m}$ and is thickest in the northwestern part of the site-scale model area. The Topopah Spring welded hydrogeologic unit ranges in thickness from about $60 \mathrm{~m}$ to $340 \mathrm{~m}$. This unit is thickest near the central part of the model area and thins abruptly to the northeast.

The development of the numerical grid was performed by using a mesh generator to create the grid from given center nodes. A mesh generator previously used for vertically uniform layers was adapted to deal with the occurrence of non-uniform thickness within hydrogeologic units, and also to explicitly account for the offsets along three normal faults. A relatively fine grid formed by three sublayers for each of the Tiva Canyon and Paintbrush units, six sublayers within the Topopah Spring unit, and five within the Calico Hills unit was defined to allow sufficient resolution of major hydrogeologic and lithological variability within the units. A double number of gridblocks was used for the fault zones in order to represents the displacements of the sublayers on each side of the fault zone.

The different hydrogeologic units, and their main lithologic zones were modeled as porous layers by including various matrix rock properties, such as porosity, absolute permeability, relative permeability and capillary pressure curves, for the seventeen sublayers of the model. Rock matrix properties for those seventeen sublayers, properties for fractured media and fault zones were based on numerous previous reports and studies, as well as recent data sets. The massive welded fractured tuffs were modeled by using the equivalent continuum approximation for matrix and fracture flow. Properties for the fault zones were chosen to represent two extreme conditions, such as a porous high-permeability zone with low potential capillary attraction for water or a low permeability zone, with high potential capillary attraction.

First, one-dimensional simulations were performed with a simplified data set of hydrogeologic properties to check the accuracy of the numerical results for different numbers of vertical sublayers.

Two-dimensional simulations were then carried out to investigate the role of major faults (Ghost Dance-, Abandoned Wash-, and Dune Wash faults) on fluid flow within the unsaturated zone of the site-scale model for two northwest-southeast vertical cross-sections. The distribution of moisture-flow was calculated for infiltration rates varying over three orders of magnitude. As hydrological properties of the faults are not known at present, bounding calculations were performed in order to study their potential effects.

The approach taken in the design of the numerical grid, and the numerical capabilities of the TOUGH2 simulator allowed the results to be analyzed 
in terms of preferential pathways, lateral flow, and capillary barriers. All the results shown here were strongly dependent on the characteristic curves chosen for the different rock types. For example, the assumed characteristic curves of a high permeability fault resulted in relatively small absolute values of capillary pressures, but very low liquid saturations at steady-state. The relatively large capillary pressures prevented flow from neighboring formations from entering the fault, and in fact some of the infiltration prescribed on the top of the fault was lost to surrounding rocks. Significant vertical flow occurs in a fault only if its properties are such that its characteristic curves are similar to those of the adjacent formations (e.g. similar air entry pressure), and the absolute saturated permeability was significantly larger. Whether such a combination of capillary and flow properties can be considered physically realistic requires further study.

Preliminary three-dimensional simulations with the uncalibrated model were conducted in order to evaluate various assumptions concerning fault hydrological characteristics at Yucca Mountain and to investigate the effects of uniform and non-uniform infiltration patterns at the ground surface. Keeping in mind the uncertainties associated with the uncalibrated model and without the results of extensive sensitivity analyses, the following conclusions can be reached from these simulations:

(1) When uniform infiltration rates are assumed at the ground surface, lateral flow and three-dimensional effects due to the complex stratigraphy at the site, and major fault offsets, lead to variable areal distributions of discharge at the water table. Non-uniform infiltration patterns increase this effect.

(2) When the major faults are assumed to have hydrologic properties that cause them to act as capillary barriers, lateral flow causes build-up of moisture updip from the faults and subsequent vertical migration. Conversely, when the faults are assumed to readily absorb water and transmit it downward, lateral flow is enhanced and relatively dry conditions are found near the faults.

(3) The hydrological characteristics of major faults at Yucca Mountain is extremely important because the flow field is strongly influenced by the hydrological character of the faults. Careful measurements of saturation and capillary pressure conditions in the rock masses near the faults in addition to the physical testing of the faults themselves, may allow much to be inferred concerning the long-term behavior in the faults in the hydrologic system.

(4) Non-uniform distribution of infiltration is likely at Yucca Mountain and leads to enhanced lateral flow in different parts of the mountain, 
more complex three-dimensional flow patterns, and the more likely existence of perched water in different parts of the mountain.

(5) The use of the site-scale model (and other models) to predict conditions in new boreholes as well as in the Exploratory Studies Facility is critical for understanding the site, ensuring the quality and accuracy of the model as well as for securing confidence by the public and the scientific community in the model. This process has started with use of the model for predicting conditions in borehole UZ \#16.

The calibrated site-scale model will eventually incorporate all available geological, geochemical, and hydrological data in order to estimate moisture, gas, heat, and chemical transport within the unsaturated zone at Yucca Mountain. Extensive analyses will be performed on the data to quantify statistically its variability across the model domain. The model will be used to investigate specific hypotheses and approximations, such as the influence of the grid resolution and orientation used to represent geological heterogeneities on the numerical results. Other sensitivity analyses will investigate the effect of spatial and temporal variation of infiltration, the effect of short- and long-term barometric variations, or the influence of the geothermal gradient on moisture- and gas-flows. Additionally, studies will be made of the effect of the equivalent continuum approximation in representing fracture-matrix interaction. The assumptions concerning the flow characteristics of the faults in the model domain have been evaluated to some degree in this report. However, additional evaluations of the effects of fault characteristic will be performed by expanding the model grid so that faults near the present model boundaries can be assessed. Much of this work is scheduled to be performed during FY95 and subsequent years, and will be discussed in future iterations of this report.

\section{ACKNOWLEDGMENT}

This work was prepared under U.S. Department of Energy Contract No. DE-AC03-76SF00098, and DE-AI08-92NW10874 administered by the Nevada Operations Office in cooperation with the U.S. Geological Survey, Denver. Review of this report by Z. Aunzo and Y. Tsang of LBL, and Bob Andrews and Srikanta Mishra of Intera is greatly appreciated. The generation of this grid would never have occurred without the work and advice of P. Fuller, LBL, and C. Lai, LBL. 
1. J. RULON, G.S. BODVARSSON, and P. MONTAZER, "Preliminary Numerical Simulations of Groundwater Flow in the Unsaturated Zone, Yucca mountain, Nevada," LBL 20553, Lawrence Berkeley Laboratory, 91 p. (1986).

2. J.S.Y. WANG and T.N. NARASIMHAN, "Hydrologic Modeling of Vertical and Lateral Movement of Partially Saturated Fluid Flow Near a Fault Zone at Yucca Mountain," SAND87-7070, Sandia National Laboratories and LBL-23510, Lawrence Berkeley Laboratory, 98 p. (1987).

3. J.D. OSNES and J.D. NIELAND, "Preliminary Numerical Simulations of the Pre-waste-emplacement Hydrology for the Yucca Mountain Site," Technical Letter Memorandum RSI/TLM-165, Research Specialists Inc., 27 p. (1990).

4. M.L. ROCKHOLD, B. SAGAR, and M.P. CONNELLY, "Multi-dimensional Modeling of Unsaturated Flow in the Vicinity of Exploratory Shafts and Fault Zones at Yucca Mountain, Nevada," Proceedings of the First International High Level Radioactive Waste Management Conference, Las Vegas, NV, pp. 1192-1199 (1990). American Nuclear Society, La Grange Park, Ill.

5. K.H. BIRDSELL, K. CAMPBELL, K.G. EGGERT, and B.J. TRAVIS, "Simulation of Radioactive Retardation at Yucca Mountain using a Stochastic Mineralogical / Geochemical Model," Proceedings of the First International High Level Radioactive Waste Management, Conference, Las Vegas, NV, pp. 153-162 (1990). American Nuclear Society, La Grange Park, Ill.

6. Y.W. TSANG, K. PRUESS, and J.S.Y. WANG, "The Role of Fault Zones in Affecting Multiphase Flow at Yucca Mountain," Proceedings of the Fourth International High-level Radioactive Waste Management Conference, Las Vegas, NV, April 26-30, 1993, pp. 660-666. American Nuclear Society, La Grange Park, Ill.

7. P. MONTAZER and W.E. WILSON, "Conceptual Hydrologic Model of Flow in the Unsaturated Zone, Yucca Mountain, Nevada," Water Resources Investigations Report 84-4355, U.S. Geological Survey, 55 p. (1984).

8. J.S.Y. WANG and T.N. NARASIMHAN, "Hydrologic Mechanisms Governing Fluid Flow in Partially Saturated, Fractured, Porous Tuff at Yucca Mountain," Water Resourc. Res., 21, pp. 1861-1874 (1985). 
9. R.B. SCOTT and J. BONK, "Preliminary Geologic Map of Yucca Mountain with Geologic Sections, Nye County, Nevada," Open -File Report 84-494, U.S. Geological Survey, scale 1:12,000 (1984).

10. C.S.WITTWER, G.S. BODVARSSON, M.P. CHORNACK, A.L. FLINT, L.E. FLINT, B.D. LEWIS, R.W. SPENGLER, and C.A. RAUTMAN, "Design of a Three-dimensional Site-Scale Model for the Unsaturated Zone at Yucca Mountain, Nevada," Proceedings of the Third International High Level Radioactive Waste Management Conference, Las Vegas, NV, pp. 263-271 (1992). American Nuclear Society, La Grange Park, Ill.

11. L.E. FLINT and A.L. FLINT, "The Influence of Long Term Climate Change on Net Infiltration at Yucca Mountain, Nevada," Proceedings of the Fourth International High Level Radioactive Waste Management Conference, Las Vegas, NV, April 26-30, 1993, pp. 152 to 159. American Nuclear Society, La Grange Park, Ill.

12. R.H. BROOKS and A.T. COREY, "Properties of Porous Media Affecting Fluid Flow," J. Irrigation and Drainage Div., Proc. Am. Soc. Civ. Eng., 92, IR2, 61-88 (1966).

13. M.Th. VAN GENUCHTEN, "A Closed-Form Equation for Predicting the Hydraulic Conductivity of Unsaturated Soils," Soil. Sci. Soc. Am. J., 44, 892-898 (1980).

14. E.A. KLAVETTER and R.R. PETERS, "Estimation of Hydrologic Properties of an Unsaturated Fractured Rock Mass," SAND84-2642, Sandia National Laboratories (1986).

15. K. PRUESS, "TOUGH2-A General-purpose Numerical Simulator for Multiphase Fluid and Heat Flow," LBL-29400, Lawrence Berkeley Laboratory, 103 p. (1990).

16. F.B. NIMICK and R.L. WILLIAMS, "A Three-dimensional Geologic Model of Yucca Mountain, Southern Nevada," SAND83-2593, Sandia National Laboratories, 72 p. (1984).

17. P.-L. TIEN, M.D. SIEGL, C.D. UNDEGRAFF, K.K. WAHI, and R.V. GUZOWSKI, "Repository Site Data Report for Unsaturated Tuff, Yucca Mountain," NUREG/CR-4110 or SAND84-2668, Sandia National Laboratories, 384 p. (1985).

18. R.B. SCOTT, R.W. SPENGLER, S. DIEHL, A.R. LAPPIN, and M.P. CHORNACK, "Geologic Character of Tuffs in the Unsaturated Zone at Yucca Mountain, Southern Nevada," in Role of the unsaturated zone in radioactive and hazardous waste disposal, J.W. MERCER, P.S.C. RAO, I.W. MARINE (eds), Ann Arbor Science, pp. 289-335 (1983). 
19. L.E. FLINT and A.L. FLINT, "Preliminary Permeability and Water-retention Data for Nonwelded and Bedded Tuff Samples, Yucca Mountain Area, Nye county, Nevada," Open-File Report 90-569, U.S. Geological Survey, 57 p. (1990).

20. MANAGEMENT and OPERATING CONTRACTOR (M\&O), "Yucca Mountain Project Draft Stratigraphic Compendium," October 11, 1994.

21. EG\&G ENERGY MEASUREMENTS, INC., "Yucca Mountain Site Characterization Project Site Atlas," October, 1993.

22. A.L. FLINT and L.E. FLINT, "Spatial Distribution of Potential Near Surface Moisture Flux at Yucca Mountain," in Proceedings of the Fifth International High Level Radioactive Waste Management Conference, Las Vegas, NV, May 22-26, 1994, pp. 2352-2358. American Nuclear Society, La Grange Park, Ill.

23. E.P. WEEKS, "Effect of Topography on Gas Flow in Unsaturated Fractured Rock: Concepts and Observations," Proceedings of the American Geophysical Union Symposium on Flow and Transport in Unsaturated Fractured Rock, pp. 165-170, (1990).

24. D.C. BUESCH, J.E. NELSON, R.P. DICKERSON, R.W. SPENGLER, "Development of 3-D Lithostratographic and Confidence Models at Yucca Mountain, Nevada," Proceedings of the Fourth International High Level Radioactive Waste Management Conference, Las Vegas, NV, April 26-30, 1993, pp. 943-948. American Nuclear Society, La Grange Park, 111.

25. C.S. WITTWER, G.S. BODVARSSON, M.P. CHORNAK, A.L. FLINT, L.E. FLINT, B.D. LEWIS, R.W. SPENGLER, and C.A. RAUTMAN, "Development of a Three-dimensional Site-Scale Model for the Unsaturated Zone at Yucca Mountain, Nevada," Radioactive Waste Management and Environmental Restoration, 1994, Vol. 19, pp.147-167. Harwood Academic Publishers GmbH, U.S.

26. C.S. WITTWER, G. CHEN, and G.S. BODVARSSON, "Studies of the Role of Fault Zones on Fluid Flow Using the Site-Scale Numerical Model of Yucca Mountain," Proceedings of the Fourth International High Level Radioactive Waste Management Conference, Las Vegas, NV, April 26-30, 1993, pp. 667-674. American Nuclear Society, La Grange Park, Ill.

27. W.J. CARR, "Regional Structural Setting of Yucca Mountain, Southwestern Nevada, and Late Cenozoic Rates of Tectonic Activity in Part of the Southwestern Great Basin, Nevada and California," Open-File Report 84-854, U.S. Geological Survey, 109 p. (1984). 
28. J.H. ROBISON, "Ground-water Level Data and Preliminary Potentiometric Surface Map of Yucca Mountain and Vicinity, Nye County Nevada," Water Resources Investigations Report 84-4197, U.S. Geological Survey, 8 p. (1984).

29. T.S. ORTIZ, R.L. WILLIAMS, F.B. NIMICK, B.C. WHITTET, and D.L. SOUTH, "A Three-dimensional Model of Reference Thermal-mechanical and Hydrological Stratigraphy at Yucca Mountain, Southern Nevada," SAND84-1076, Sandia National Laboratories, 96 p. (1985).

30. R.W. SPENGLER, C.A. BRAUN, R.M. LINDEN, L.G. MARTIN, D.M. ROSS-BROWN, and R.L. BLACKBURN, "Structural Character of the Ghost Dance Fault, Yucca Mountain, Nevada," Proceedings of the Fourth International High-level Radioactive Waste Management Conference, Las Vegas, NV, April 26-30, 1993, pp. 653-659. American Nuclear Society, La Grange Park, Ill.

31. EG\&G ENERGY MEASUREMENTS, INC., "Ground Level Map of Yucca Mountain," (1990).

32. J.M. GEMMEL, "Water Levels in Periodically Measured Wells in the Yucca Mountain area, Nevada, 1988," U.S. Geological Survey, OpenFile Report OFR-90-113, 47 p. (1990).

33. E.M. ERVIN, R.R. LUCKEY, and D.J. BURKHARDT, "Summary of Revised Potentiometric-Surface Map for Yucca Mountain and Vicinity, Nevada," Proceedings of the High Level Radioactive Waste Management Conference, Las Vegas, Nevada, April 26-30, 1993, pp. 1554-1558. American Nuclear Society, La Grange Park, Ill.

34. R.R. PETERS, E.A. KLAVETTER, I.J. HALL, S.C. BLAIR, P.R. HELLER and G.W. GEE, "Fracture and Matrix Hydrologic Characteristics of Tuffaceous Materials from Yucca Mountain, Nye County, Nevada," Sandia National Laboratories, SAND84-1471 (1984).

35. N.K. HAYDEN, J.K. JOHNSTONE, and R.P. PETERS, “Parameters and Material Properties for Hydrologic Modeling of the Topopah Spring Unit," Memo to distribution, Sandia National Laboratories (1983).

36. K. PRUESS, J.S.Y. WANG, and Y.W. TSANG, “On Thermohydrological Conditions Near High-level Nuclear Wastes Emplaced in Partially Saturated Fractured Tuff, Part 2. Effective Continuum Approximation," Water Resour. Res., 26(6), 1249-1261 (1990).

37. L.A. ANDERSON, "Water Permeability and Related Rock Properties Measured on Core Samples from the Yucca Mountain USW GU-3/G3 and USW G-4 Boreholes, Nevada Test Site, Nevada," U. S. Geological Survey Open-File Report 92-201. 
38. J.S.Y. WANG, "Variations of Hydrological Parameters of Tuff and Soil," Proceedings of the Third International Conference on High-Level Radioactive Waste Management, Las Vegas, NV, pp. 77-731. American Nuclear Society, La Grange Park, Ill. (1992).

39. P.H. NELSON, D.C. MULLER, U. SCHMISCHAL, and J.E. KIBLER, "Geophysical Logs and Core Measurements from Forty Boreholes at Yucca Mountain, Nevada," Geophysical Investigations Map MAP GP1001, U.S. Geological Survey (1991).

40. BURGER, PAUL A., and SCOFIELD, KEVIN M. "Perched Water At Yucca Mountain--Implications on the Exploratory Studies Facility, Nye County, Nevada," U.S. Geological Survey, Draft Water Resource Investigations Report 94-xxx.

41. FABRYKA-MARTIN, J.T., WIGHTMAN, S.J., MURPHY, W.J., WICKHAM, M.P., CAFFEE, M.W., MINZ, G.J., OUTHON, J.R., and SHARMA, P. "Distribution of Chlorine-36 in the Unsaturated Zone at Yucca Mountain: An Indicator of Fast Transport Paths," In Conference Proceedings FOCUS '93: Site Characterization and Model Validation, Las Vegas, NV, September 26-29, 1993.

42. GAUTHIER, JOHN H., WILSON, MICHAEL L., and LAFFER, FRANZ C. "Estimating the Consequences of Significant Fracture Flow at Yucca Mountain," Proceedings of the Third International conference on High-Level Radioactive Waste Management, Las Vegas, NV, pp.727-731. American Nuclear Society, La Grange Park, Ill. (1992). 


\title{
Appendix A:
}

\author{
List of reports on boreholes \\ used in the present study.
}


BENTLEY, C.B., "Geohydrologic Data for Well USW G-4 Yucca Mountain Area, Nye County, Nevada," U.S. Geological Survey Open-File Report 84-63, 48 p. (1984).

BENTLEY, C.B., ROBISON, J.H., and SPENGLER, R.W., "Geohydrologic Data for Well USW H-5 Yucca Mountain area, Nye County, Nevada," U.S. Geological Survey (1983).

CRAIG, R.W., JOHNSON, K.A., "Geohydrologic Data for Test Well UE-25p\#1, Yucca Mountain Area, Nye County, Nevada," U.S. Geological Survey Open-File Report 84-450, 63 p. (1984).

CRAIG, R.W., REED, R.L., and SPENGLER, R.W., "Geohydrologic Data for Well USW H-6, Yucca Mountain Area, Nye County, Nevada," U.S. Geological Survey Open-File Report 83-856, 35 p. (1983).

KUME, J. and HAMMERMEISTER, D.P., "Geohydrologic Data from Test Hole USW UZ-7, Yucca Mountain Area, Nye Country, Nevada," U.S. Geological Survey Open-File Report 88-465, 37 p. (1990).

LAHOUD, R.G., LOBMEYER, D.H., and WHITFIELD, M.S., Jr., "Geohydrology of Volcanic Tuff Penetrated by Test Well UE-25b\#1, Yucca Mountain Area, Nye County, Nevada," U.S. Geological Survey Water-Resources Investigations Report 84-4253, 44 p. (1984).

LOBMEYER, D.H., WHITFIELD, M.S., JR, LAHOUD, R.R., and BRUCKHEIMER, L., "Geohydrologic Data for Test Well UE-25b-1H, Nevada Test Site, Nye County, Nevada," U.S. Geological Survey Open-File Report 83-855, 48 p. (1983).

RUSH, F.E., THORDARSON, W., and BRUCKHEIMER, L., "Geohydrologic and Drill-hole Data for Test Well USW-H1, Adjacent to Nevada Test Site, Nye County, Nevada," U.S. Geological Survey Open-File Report 83-141, 38 p. (1983).

RUSH, F.E., THORDARSON, W., and PYLES, D.G., "Results of Hydraulic Tests in Well USW H-1, Nevada Test Site, Nye County, Nevada," U.S. Geological Survey Water-Resources Investigations Report 84-4032, 56 p. (1984).

SCOTT, R.B., and CASTELLANOS, M., "Stratigraphic and Structural Relations of Volcanic Rocks in Drill Holes USW GU-3 and USW G-3, Yucca Mountain Area, Nye County, Nevada," U.S. Geological Survey Open-File Report 84-491, 121 p. (1984).

SPENGLER, R.W., and CHORNACK, M.P., "Stratigraphic and Structural Characteristics of Volcanic Rocks in Core Hole USW G-4, with a Section on 
Geophysical Logs by Muller, D.C., and Kibler, J.E., Yucca Mountain Area, Nye County, Nevada," U.S. Geological Survey Open-File Report 84789, 77 p. (1984).

SPENGLER, R.W., and ROSENBAUM, J.G., "Preliminary Interpretations of Geologic Results Obtained from Boreholes UE25a-4, -5, -6, and -7, Yucca Mountain Area, Nevada Test Site," U.S. Geological Survey Open-File Report 80-929, 33 p. (1980).

THORDARSON, W., RUSH, F.E., SPENGLER, R.W., and WADDELL, S.J., "Geohydrologic and drill-hole data for test well USW H-3, Yucca Mountain area, Nye County, Nevada," U.S. Geological Survey Open-File Report 84-149, 28 p. (1984).

THORDARSON, W., RUSH F.E., and WADDELL, S.J., "Geohydrology of rocks penetrated by test well USW H-3, Yucca Mountain area, Nye County, Nevada," U.S. Geological Survey Water-Resources Investigations Report 84--4272, 38 p. (1984).

TIEN, P.L., SIEGL, M.D., Undegraff, C.D., WAHI, K.K., and GUZOWSKI, R.V., "Repository Site Data Report for Unsaturated Tuff," NUREG/CR-4110 or SAND84-2668, Yucca Mountain area, Nye County, Nevada, Sandia National Laboratories, 384 p. (1985).

WHITFIELD, M.S., JR, ESHOM, E.P., THORDARSON, W., and SCHAEFER, D.H., "Geohydrology of Test Well USW H-4, Yucca Mountain Area, Nye County, Nevada," U.S. Geological Survey Water-Resources Investigations Report 85-4030, 33 p. (1985).

WHITFIELD, M.S., JR, THORDARSON, W., and ESHOM, E.P., "Geohydrologic and Drill-hole Data for Test Well USW H-4, Yucca Mountain Area, Nye County, Nevada," U.S. Geological Survey Open-File Report 84-449, 39 p. (1984). 


\section{Appendix B}


Table A. Nevada State Plane coordinates of existing and proposed boreholes used for the site-scale model design.

\begin{tabular}{|c|c|c|c|}
\hline $\begin{array}{c}\text { Grid } \\
\text { Designation of } \\
\text { Center Node }\end{array}$ & $\begin{array}{l}\text { Nevada State } \\
\text { Plane North } \\
\text { Coordinate }(\mathbf{m})\end{array}$ & $\begin{array}{c}\text { Nevada State } \\
\text { Plane East } \\
\text { Coordinate }(\mathrm{m})\end{array}$ & Borehole Name \\
\hline 36 & 237550.58 & 170458.48 & USW GA1 \\
\hline 38 & 237385.61 & 170841.58 & USW G2 \\
\hline 103 & 235084.87 & 170755.30 & USW UZ1 \\
\hline 105 & 235051.73 & 172167.80 & UE 25 WT18 \\
\hline 112 & 234848.46 & 170992.95 & USW G1 \\
\hline 115 & 234773.52 & 171415.85 & USW H1 \\
\hline 129 & 234266.54 & 172558.01 & UE 25 UZ5 \\
\hline 132 & 234242.38 & 173138.64 & UE 25 WT4 \\
\hline 134 & 234077.84 & 172050.96 & UE 25 a 4 \\
\hline 147 & 233768.30 & 172137.36 & UE 25 a 5 \\
\hline 152 & 233670.13 & 170355.38 & USW H5 \\
\hline 157 & 233417.99 & 171627.28 & USW G4 \\
\hline 158 & 233446.16 & 172059.82 & UE 25 a 6 \\
\hline 159 & 233552.96 & 172354.80 & UE 25 a7 \\
\hline 162 & 233141.57 & 172623.47 & UE 25 a1 \\
\hline 194 & 232148.98 & 171880.11 & USW H4 \\
\hline 205 & 231849.33 & 171274.30 & USW WT2 \\
\hline 206 & 231902.84 & 171575.36 & USW UZ7 \\
\hline 211 & 231566.01 & 170177.46 & USW UZ6 \\
\hline 239 & 230594.03 & 170216.06 & USW H3 \\
\hline 257 & 229801.09 & 171827.70 & USW WT1 \\
\hline 265 & 229447.30 & 170225.65 & USW G3 \\
\hline a & 233246.18 & 172643.72 & UE 25 b1 \\
\hline b & 234304.51 & 172559.26 & UE 25 UZ4 \\
\hline
\end{tabular}


Table A. Nevada State Plane coordinates of existing and proposed boreholes used for the site-scale model design.

\begin{tabular}{|c|c|c|c|}
\hline $\begin{array}{c}\text { Grid } \\
\text { Designation of } \\
\text { Center Node }\end{array}$ & $\begin{array}{l}\text { Nevada State } \\
\text { Plane North } \\
\text { Coordinate (m) }\end{array}$ & $\begin{array}{c}\text { Nevada State } \\
\text { Plane East } \\
\text { Coordinate (m) }\end{array}$ & Borehole Name \\
\hline c & 237919.50 & 172066.88 & UE 25 WT6 \\
\hline d & 236043.11 & 173856.36 & UE 25 WT16 \\
\hline e & 228118.29 & 172581.39 & UE 25 WT17 \\
\hline $\mathrm{f}$ & 229419.94 & 170231.20 & USW GU3 \\
\hline 127 & 234439.05 & 171702.37 & USW UZ4 \\
\hline 126 & 234364.68 & 171579.54 & USW UZ5 \\
\hline i & 230297.68 & 168826.07 & USW WT7 \\
\hline j & 228225.37 & 168646.48 & USW WT10 \\
\hline $\mathrm{k}$ & 232653.49 & 168882.04 & USW H6 \\
\hline 1 & 230480.98 & 174188.48 & UE $25 \mathrm{p} 1$ \\
\hline $\mathrm{m}$ & 230762.82 & 173638.60 & UE $25 \mathrm{c} 1$ \\
\hline $\mathrm{n}$ & 230687.51 & 173624.38 & UE 25 c2 \\
\hline 0 & 230706.14 & 173600.33 & UE 25 c3 \\
\hline 140 & 234048.30 & 170890.69 & SD2 \\
\hline 166 & 233098.85 & 170488.36 & SD3 \\
\hline 170 & 232948.49 & 171512.53 & SD4 \\
\hline 183 & 232615.74 & 171966.64 & SD5 \\
\hline 189 & 232327.70 & 170497.50 & SD6 \\
\hline 213 & 231222.80 & 171011.09 & SD7 \\
\hline 210 & 231855.57 & 171788.33 & SD10 \\
\hline 219 & 231657.14 & 171986.45 & SD12 \\
\hline 280 & 228957.64 & 170732.41 & UZ10 \\
\hline 62 & 236399.06 & 171632.67 & USW G5 \\
\hline
\end{tabular}


Table A. Nevada State Plane coordinates of existing and proposed boreholes used for the site-scale model design.

\begin{tabular}{|c|c|c|c|}
\hline $\begin{array}{c}\text { Grid } \\
\text { Designation of } \\
\text { Center Node }\end{array}$ & $\begin{array}{c}\text { Nevada State } \\
\text { Plane North } \\
\text { Coordinate (m) }\end{array}$ & $\begin{array}{c}\text { Nevada State } \\
\text { Plane East } \\
\text { Coordinate (m) }\end{array}$ & Borehole Name \\
\hline \hline Caption: - number 36 to 280: existing and proposed borehole designation inside of \\
the model boundary; \\
- number " $\mathrm{a}$ " to " $\mathrm{o}$ ": boreholes outside of the model area. \\
\hline
\end{tabular}


Table B. Nevada State Plane coordinates for the 286 center nodes of the horizontal grid.

\begin{tabular}{|c|c|c|c|c|c|}
\hline $\begin{array}{c}\text { Grid } \\
\text { Designation } \\
\text { of Center } \\
\text { Node }\end{array}$ & $\begin{array}{c}\text { Nevada } \\
\text { State Plane } \\
\text { North } \\
\text { Coordinate } \\
\text { (m) }\end{array}$ & $\begin{array}{c}\text { Nevada } \\
\text { State Plane } \\
\text { East } \\
\text { Coordinate } \\
\text { (m) }\end{array}$ & $\begin{array}{c}\text { Grid } \\
\text { Designation } \\
\text { of Center } \\
\text { Node }\end{array}$ & $\begin{array}{c}\text { Nevada } \\
\text { State Plane } \\
\text { North } \\
\text { Coordinate } \\
\text { (m) }\end{array}$ & $\begin{array}{l}\text { Nevada } \\
\text { State Plane } \\
\text { East } \\
\text { Coordinate } \\
\text { (m) }\end{array}$ \\
\hline 12 & 238524.01 & 171000.40 & 157 & 233417.99 & 171627.28 \\
\hline 13 & 238286.41 & 171295.25 & 158 & 233446.16 & 172059.82 \\
\hline 14 & 238037.57 & 171554.95 & 159 & 233552.96 & 172354.80 \\
\hline 15 & 237785.17 & 171844.97 & 160 & 233374.22 & 172832.31 \\
\hline 16 & 237585.21 & 172159.61 & 161 & 233366.18 & 173292.50 \\
\hline 17 & 237338.16 & 172508.67 & 162 & 233141.57 & 172623.47 \\
\hline 18 & 237136.41 & 172838.48 & 163 & 233046.55 & 172978.21 \\
\hline 19 & 236900.78 & 173142.77 & 164 & 233249.26 & 169897.04 \\
\hline 20 & 236607.17 & 173495.58 & 165 & 233193.60 & 170161.03 \\
\hline 21 & 238584.31 & 170592.47 & 166 & 233098.85 & 170488.36 \\
\hline 22 & 238317.46 & 170822.39 & 167 & 233047.68 & 170826.34 \\
\hline 23 & 238146.95 & 170547.15 & 168 & 232990.59 & 171154.72 \\
\hline 24 & 237965.35 & 171045.34 & 169 & 232940.28 & 171373.22 \\
\hline 26 & 237814.26 & 171362.66 & 170 & 232948.48 & 171512.53 \\
\hline 27 & 237790.56 & 170754.23 & 171 & 232884.09 & 171772.41 \\
\hline 28 & 237637.86 & 171163.59 & 172 & 232830.02 & 172178.90 \\
\hline 29 & 237547.95 & 171614.15 & 173 & 232796.31 & 172413.83 \\
\hline 30 & 237262.19 & 171900.25 & 174 & 232840.00 & 172800.18 \\
\hline 31 & 237105.93 & 172339.93 & 175 & 232868.17 & 173240.05 \\
\hline 32 & 236910.06 & 172698.09 & 176 & 232832.59 & 169884.89 \\
\hline 33 & 236678.35 & 172969.03 & 177 & 232777.29 & 170145.85 \\
\hline 34 & 236364.94 & 173307.21 & 178 & 232725.02 & 170407.16 \\
\hline
\end{tabular}


Table B. Nevada State Plane coordinates for the 286 center nodes of the horizontal grid.

\begin{tabular}{|c|c|c|c|c|c|}
\hline $\begin{array}{c}\text { Grid } \\
\text { Designation } \\
\text { of Center } \\
\text { Node }\end{array}$ & $\begin{array}{l}\text { Nevada } \\
\text { State Plane } \\
\text { North } \\
\text { Coordinate } \\
\text { (m) }\end{array}$ & $\begin{array}{l}\text { Nevada } \\
\text { State Plane } \\
\text { East } \\
\text { Coordinate } \\
\text { (m) }\end{array}$ & $\begin{array}{c}\text { Grid } \\
\text { Designation } \\
\text { of Center } \\
\text { Node }\end{array}$ & $\begin{array}{l}\text { Nevada } \\
\text { State Plane } \\
\text { North } \\
\text { Coordinate } \\
\text { (m) }\end{array}$ & $\begin{array}{l}\text { Nevada } \\
\text { State Plane } \\
\text { East } \\
\text { Coordinate } \\
\text { (m) }\end{array}$ \\
\hline 35 & 236246.50 & 173686.78 & 179 & 232736.42 & 170780.49 \\
\hline 36 & 237550.58 & 170458.48 & 180 & 232614.40 & 171138.12 \\
\hline 37 & 237515.50 & 171001.63 & 181 & 232538.06 & 171368.93 \\
\hline 38 & 237385.61 & 170841.58 & 182 & 232555.53 & 171586.19 \\
\hline 39 & 237107.74 & 171122.73 & 183 & 232615.74 & 171966.64 \\
\hline 40 & 237293.42 & 171347.48 & 184 & 232542.80 & 172296.10 \\
\hline 41 & 237397.94 & 171452.01 & 185 & 232529.46 & 172643.75 \\
\hline 42 & 237075.44 & 171736.86 & 186 & 232512.68 & 173047.58 \\
\hline 43 & 236906.69 & 172178.14 & 187 & 232443.74 & 169897.55 \\
\hline 44 & 236589.36 & 172445.15 & 188 & 232413.05 & 170106.06 \\
\hline 45 & 236404.92 & 172758.55 & 189 & 232327.70 & 170497.50 \\
\hline 46 & 236149.84 & 173149.71 & 190 & 232305.48 & 170732.85 \\
\hline 47 & 235922.23 & 173464.17 & 191 & 232261.59 & 171105.83 \\
\hline 48 & 236938.10 & 171597.72 & 192 & 232174.36 & 171350.73 \\
\hline 49 & 237070.47 & 170629.53 & 193 & 232158.48 & 171564.06 \\
\hline 50 & 236759.38 & 171392.24 & 194 & 232148.98 & 171880.11 \\
\hline 51 & 236572.07 & 171834.41 & 195 & 232084.44 & 172219.39 \\
\hline 52 & 236725.11 & 171996.91 & 196 & 232228.02 & 172592.90 \\
\hline 53 & 236399.22 & 172232.17 & 197 & 232140.42 & 172997.62 \\
\hline 54 & 236260.08 & 172630.83 & 198 & 231836.30 & 172943.39 \\
\hline 55 & 235967.01 & 172952.96 & 199 & 231855.51 & 172531.53 \\
\hline 56 & 235708.19 & 173245.30 & 200 & 232077.73 & 169820.66 \\
\hline
\end{tabular}


Table B. Nevada State Plane coordinates for the 286 center nodes of the horizontal grid.

\begin{tabular}{|c|c|c|c|c|c|}
\hline $\begin{array}{c}\text { Grid } \\
\text { Designation } \\
\text { of Center } \\
\text { Node }\end{array}$ & $\begin{array}{c}\text { Nevada } \\
\text { State Plane } \\
\text { North } \\
\text { Coordinate } \\
(m)\end{array}$ & $\begin{array}{c}\text { Nevada } \\
\text { State Plane } \\
\text { East } \\
\text { Coordinate } \\
(\mathrm{m})\end{array}$ & $\begin{array}{c}\text { Grid } \\
\text { Designation } \\
\text { of Center } \\
\text { Node }\end{array}$ & $\begin{array}{c}\text { Nevada } \\
\text { State Plane } \\
\text { North } \\
\text { Coordinate } \\
\text { (m) }\end{array}$ & $\begin{array}{c}\text { Nevada } \\
\text { State Plane } \\
\text { East } \\
\text { Coordinate } \\
\text { (m) }\end{array}$ \\
\hline 57 & 235518.39 & 173604.18 & 201 & 232031.52 & 170030.42 \\
\hline 58 & 236799.89 & 170499.31 & 202 & 232017.78 & 170277.82 \\
\hline 59 & 236805.41 & 170896.55 & 203 & 231924.66 & 170651.15 \\
\hline 60 & 236625.62 & 170804.68 & 204 & 231855.26 & 171110.28 \\
\hline 61 & 236532.32 & 171205.65 & 205 & 231849.33 & 171274.30 \\
\hline 62 & 236399.06 & 171632.67 & 206 & 231902.84 & 171575.36 \\
\hline 63 & 236256.17 & 172089.30 & 207 & 231774.61 & 172213.67 \\
\hline 64 & 236056.21 & 172456.20 & 208 & 231592.38 & 169791.22 \\
\hline 65 & 236550.17 & 170374.63 & 209 & 231573.47 & 169951.93 \\
\hline 66 & 236376.08 & 170704.61 & 210 & 231855.57 & 171788.33 \\
\hline 67 & 236274.21 & 171126.10 & 211 & 231566.01 & 170177.46 \\
\hline 68 & 236250.13 & 171461.43 & 212 & 231429.68 & 170651.31 \\
\hline 69 & 236042.85 & 171916.63 & 213 & 231222.80 & 171011.09 \\
\hline 70 & 235928.50 & 172339.72 & 214 & 231133.93 & 171179.11 \\
\hline 71 & 235788.64 & 172796.70 & 215 & 231516.89 & 171347.14 \\
\hline 72 & 236381.82 & 170246.13 & 216 & 231576.63 & 171649.30 \\
\hline 73 & 236283.49 & 170577.71 & 217 & 231143.37 & 171595.25 \\
\hline 74 & 236030.56 & 171002.12 & 218 & 231203.12 & 171845.14 \\
\hline 75 & 235932.63 & 171390.25 & 219 & 231657.14 & 171986.45 \\
\hline 76 & 235863.94 & 171791.05 & 220 & 231212.92 & 172258.25 \\
\hline 77 & 235701.99 & 171704.36 & 221 & 231511.86 & 172591.63 \\
\hline 78 & 235735.33 & 172178.65 & 222 & 231185.26 & 172571.65 \\
\hline
\end{tabular}


Table B. Nevada State Plane coordinates for the 286 center nodes of the horizontal grid.

\begin{tabular}{|c|c|c|c|c|c|}
\hline $\begin{array}{c}\text { Grid } \\
\text { Designation } \\
\text { of Center } \\
\text { Node }\end{array}$ & $\begin{array}{l}\text { Nevada } \\
\text { State Plane } \\
\text { North } \\
\text { Coordinate } \\
\text { (m) }\end{array}$ & $\begin{array}{c}\text { Nevada } \\
\text { State Plane } \\
\text { East } \\
\text { Coordinate } \\
\text { (m) }\end{array}$ & $\begin{array}{c}\text { Grid } \\
\text { Designation } \\
\text { of Center } \\
\text { Node }\end{array}$ & $\begin{array}{l}\text { Nevada } \\
\text { State Plane } \\
\text { North } \\
\text { Coordinate } \\
\text { (m) }\end{array}$ & $\begin{array}{l}\text { Nevada } \\
\text { State Plane } \\
\text { East } \\
\text { Coordinate } \\
\text { (m) }\end{array}$ \\
\hline 79 & 235605.82 & 172599.95 & 223 & 231160.81 & 172910.02 \\
\hline 80 & 236062.87 & 170231.20 & 224 & 231499.54 & 172931.43 \\
\hline 81 & 236154.79 & 170438.92 & 225 & 231139.86 & 169691.85 \\
\hline 82 & 235933.99 & 170867.61 & 226 & 231121.48 & 169821.88 \\
\hline 83 & 235716.29 & 170433.29 & 227 & 231097.22 & 169975.82 \\
\hline 84 & 235784.50 & 170701.52 & 228 & 231075.45 & 170213.05 \\
\hline 85 & 235647.77 & 171224.54 & 229 & 230927.75 & 170684.48 \\
\hline 86 & 235541.98 & 172045.22 & 230 & 230751.33 & 171060.30 \\
\hline 87 & 235470.78 & 173042.13 & 231 & 230707.44 & 171328.75 \\
\hline 88 & 235596.25 & 170225.48 & 232 & 230704.22 & 171774.14 \\
\hline 89 & 235543.42 & 171076.92 & 233 & 230762.72 & 172008.52 \\
\hline 90 & 235469.93 & 171560.22 & 234 & 230785.89 & 172438.57 \\
\hline 91 & 235389.83 & 171901.27 & 235 & 230744.68 & 172867.20 \\
\hline 92 & 235411.58 & 172447.98 & 236 & 230671.63 & 169673.64 \\
\hline 93 & 235301.51 & 172886.94 & 237 & 230649.16 & 169864.68 \\
\hline 94 & 235275.99 & 173338.93 & 238 & 230631.49 & 170040.91 \\
\hline 95 & 235378.99 & 170608.79 & 239 & 230594.03 & 170216.06 \\
\hline 96 & 235457.11 & 170866.15 & 241 & 230504.12 & 170600.81 \\
\hline 97 & 235259.28 & 171390.95 & 242 & 230405.47 & 170890.48 \\
\hline 98 & 235154.39 & 171759.81 & 243 & 230323.59 & 171246.69 \\
\hline 99 & 235214.13 & 172323.29 & 244 & 230236.53 & 171725.25 \\
\hline 100 & 235084.44 & 172719.98 & 245 & 230281.83 & 171862.78 \\
\hline
\end{tabular}


Table B. Nevada State Plane coordinates for the 286 center nodes of the horizontal grid.

\begin{tabular}{|c|c|c|c|c|c|}
\hline $\begin{array}{c}\text { Grid } \\
\text { Designation } \\
\text { of Center } \\
\text { Node }\end{array}$ & $\begin{array}{c}\text { Nevada } \\
\text { State Plane } \\
\text { North } \\
\text { Coordinate } \\
(m)\end{array}$ & $\begin{array}{c}\text { Nevada } \\
\text { State Plane } \\
\text { East } \\
\text { Coordinate } \\
(m)\end{array}$ & $\begin{array}{c}\text { Grid } \\
\text { Designation } \\
\text { of Center } \\
\text { Node }\end{array}$ & $\begin{array}{c}\text { Nevada } \\
\text { State Plane } \\
\text { North } \\
\text { Coordinate } \\
\text { (m) }\end{array}$ & $\begin{array}{c}\text { Nevada } \\
\text { State Plane } \\
\text { East } \\
\text { Coordinate } \\
\text { (m) }\end{array}$ \\
\hline 101 & 235033.24 & 173128.98 & 246 & 230334.45 & 172121.06 \\
\hline 102 & 235232.91 & 170308.77 & 247 & 230365.12 & 172435.17 \\
\hline 103 & 235084.87 & 170755.30 & 248 & 230308.03 & 172920.34 \\
\hline 104 & 235193.45 & 171229.42 & 249 & 230079.44 & 169637.78 \\
\hline 105 & 235051.73 & 172167.80 & 250 & 230049.29 & 169920.14 \\
\hline 106 & 234944.24 & 172605.11 & 251 & 230018.78 & 170153.26 \\
\hline 107 & 234764.79 & 172980.57 & 252 & 230011.64 & 170318.44 \\
\hline 108 & 234783.86 & 173471.63 & 253 & 229985.60 & 170539.79 \\
\hline 109 & 234996.75 & 170173.38 & 254 & 229931.54 & 170764.00 \\
\hline 110 & 234880.09 & 170433.26 & 255 & 229867.50 & 171125.38 \\
\hline 111 & 234800.88 & 170740.59 & 256 & 229808.80 & 171545.80 \\
\hline 112 & 234848.46 & 170992.95 & 257 & 229801.08 & 171827.70 \\
\hline 113 & 235154.46 & 171044.02 & 258 & 229830.19 & 171991.01 \\
\hline 114 & 234627.83 & 171164.66 & 259 & 229886.91 & 172240.55 \\
\hline 115 & 234773.51 & 171415.85 & 260 & 229936.13 & 172553.78 \\
\hline 116 & 234967.46 & 171571.81 & 261 & 229973.94 & 172911.77 \\
\hline 117 & 234610.53 & 171861.83 & 262 & 229496.18 & 169526.10 \\
\hline 118 & 234809.77 & 172023.62 & 263 & 229466.02 & 169808.46 \\
\hline 119 & 234506.00 & 172279.92 & 264 & 229431.77 & 170047.30 \\
\hline 120 & 234721.28 & 172462.05 & 265 & 229447.30 & 170225.65 \\
\hline 121 & 234482.44 & 172845.90 & 266 & 229512.56 & 170522.48 \\
\hline 122 & 234543.78 & 173265.07 & 267 & 229476.88 & 170682.83 \\
\hline
\end{tabular}


Table B. Nevada State Plane coordinates for the 286 center nodes of the horizontal grid.

\begin{tabular}{|c|c|c|c|c|c|}
\hline $\begin{array}{c}\text { Grid } \\
\text { Designation } \\
\text { of Center } \\
\text { Node }\end{array}$ & $\begin{array}{c}\text { Nevada } \\
\text { State Plane } \\
\text { North } \\
\text { Coordinate } \\
\text { (m) }\end{array}$ & $\begin{array}{l}\text { Nevada } \\
\text { State Plane } \\
\text { East } \\
\text { Coordinate } \\
\text { (m) }\end{array}$ & $\begin{array}{c}\text { Grid } \\
\text { Designation } \\
\text { of Center } \\
\text { Node }\end{array}$ & $\begin{array}{c}\text { Nevada } \\
\text { State Plane } \\
\text { North } \\
\text { Coordinate } \\
\text { (m) }\end{array}$ & $\begin{array}{l}\text { Nevada } \\
\text { State Plane } \\
\text { East } \\
\text { Coordinate } \\
\text { (m) }\end{array}$ \\
\hline 123 & 234561.88 & 170211.36 & 268 & 229441.91 & 171032.26 \\
\hline 124 & 234499.09 & 170483.73 & 269 & 229402.12 & 171396.49 \\
\hline 125 & 234484.27 & 170949.28 & 270 & 229476.85 & 171832.61 \\
\hline 126 & 234364.68 & 171579.54 & 271 & 229498.78 & 172090.36 \\
\hline 127 & 234439.05 & 171702.37 & 272 & 229526.06 & 172354.88 \\
\hline 128 & 234282.32 & 172238.93 & 273 & 229526.06 & 172616.19 \\
\hline 129 & 234266.54 & 172558.01 & 274 & 229452.20 & 172878.04 \\
\hline 130 & 233268.02 & 171998.90 & 275 & 228982.11 & 169453.31 \\
\hline 132 & 234242.38 & 173138.64 & 276 & 228975.68 & 169716.94 \\
\hline 133 & 234218.67 & 171299.23 & 277 & 228954.63 & 169948.11 \\
\hline 134 & 234077.84 & 172050.96 & 278 & 228978.17 & 170218.34 \\
\hline 135 & 234017.97 & 172351.62 & 279 & 228981.91 & 170578.47 \\
\hline 136 & 233920.21 & 172764.36 & 280 & 228957.64 & 170732.41 \\
\hline 137 & 233947.31 & 173317.85 & 281 & 228909.11 & 171144.80 \\
\hline 138 & 234077.43 & 170200.47 & 282 & 229166.85 & 171593.23 \\
\hline 139 & 234060.12 & 170478.19 & 283 & 229203.76 & 171880.41 \\
\hline 140 & 234048.30 & 170890.69 & 284 & 229212.14 & 172201.12 \\
\hline 141 & 233870.31 & 171255.17 & 285 & 229208.74 & 172465.11 \\
\hline 142 & 233814.30 & 171469.92 & 286 & 229142.74 & 172712.50 \\
\hline 143 & 234042.79 & 171539.85 & 287 & 228448.96 & 169725.67 \\
\hline 144 & 233780.94 & 171675.05 & 288 & 228469.10 & 170207.63 \\
\hline 145 & 233958.77 & 171914.25 & 289 & 228497.63 & 170487.67 \\
\hline
\end{tabular}


Table B. Nevada State Plane coordinates for the 286 center nodes of the horizontal grid.

\begin{tabular}{|c|c|c|c|c|c|}
\hline $\begin{array}{c}\text { Grid } \\
\begin{array}{c}\text { Designation } \\
\text { of Center } \\
\text { Node }\end{array}\end{array}$ & $\begin{array}{c}\text { Nevada } \\
\text { State Plane } \\
\text { North } \\
\text { Coordinate } \\
\text { (m) }\end{array}$ & $\begin{array}{c}\text { Nevada } \\
\text { State Plane } \\
\text { East } \\
\text { Coordinate } \\
\mathbf{( m )}\end{array}$ & $\begin{array}{c}\text { Grid } \\
\text { Designation } \\
\text { of Center } \\
\text { Node }\end{array}$ & $\begin{array}{c}\text { Nevada } \\
\text { State Plane } \\
\text { North } \\
\text { Coordinate } \\
\text { (m) }\end{array}$ & $\begin{array}{c}\text { Nevada } \\
\text { State Plane } \\
\text { East } \\
\text { Coordinate } \\
\text { (m) }\end{array}$ \\
\hline \hline 146 & 233675.15 & 171973.10 & 290 & 228516.71 & 170821.94 \\
\hline 147 & 233768.30 & 172137.36 & 291 & 228507.42 & 171162.09 \\
\hline 148 & 233695.12 & 172534.97 & 292 & 228436.59 & 171737.87 \\
\hline 149 & 233691.89 & 173084.89 & 293 & 228843.10 & 171653.51 \\
\hline 150 & 233747.86 & 169966.43 & 294 & 228883.58 & 171962.62 \\
\hline 151 & 233710.87 & 170162.82 & 295 & 228452.10 & 172102.46 \\
\hline 152 & 233670.13 & 170355.38 & 296 & 228854.14 & 172343.45 \\
\hline 153 & 233615.63 & 170613.92 & 297 & 228446.92 & 172538.40 \\
\hline 154 & 233556.28 & 170906.80 & 298 & 228479.37 & 172785.08 \\
\hline 155 & 233489.89 & 171202.18 & 299 & 228800.62 & 172798.29 \\
\hline 156 & 233463.30 & 171401.95 & 300 & 228855.56 & 172592.63 \\
\hline
\end{tabular}

Table C. List of reports and data sources used for the design of contourand isopach maps.

\begin{tabular}{|c|c|c|}
\hline Borehole & Reference & $\begin{array}{c}\text { Hydrogeologic } \\
\text { Unit Map }\end{array}$ \\
\hline \hline UE 25 a1 & SAND 84-2668 & Tc,, , Tp \\
\hline UE 25 a 4 & OFR 80-929 & Tc, P \\
\hline UE 25 a5 & OFR 80-929 & Tc, P \\
\hline UE 25 a6 & OFR 80-929 & Tc, P \\
\hline UE 25 a7 & OFR 80-929 & Tc, P \\
\hline UE 25 b1 & OFR 83-855 & Tc,, Tp \\
\hline WE 25 c1 & WRIR 84-4253 $92-4016$ & P, Tp \\
\hline UE 25 c2 & WRIR 92-4016 & P, Tp \\
\hline UE 25 c3 & WRIR 92-4016 & P, Tp \\
\hline
\end{tabular}


Table C. List of reports and data sources used for the design of contourand isopach maps.

\begin{tabular}{|c|c|c|}
\hline Borehole & Reference & $\begin{array}{c}\text { Hydrogeologic } \\
\text { Unit Map }\end{array}$ \\
\hline UE 25 p1 & $\begin{array}{c}\text { WRIR 84-4248 } \\
\text { OFR 84-450 }\end{array}$ & $\mathrm{P}, \mathrm{Tp}$ \\
\hline UE 25 WT 4 & DSC, 1994 & $\overline{\mathrm{Tc}}, \mathrm{P}, \mathrm{Tp}$ \\
\hline UE 25 WT 6 & DSC, 1994 & - \\
\hline UE 25 WT 16 & DSC, 1994 & $\mathrm{P}, \mathrm{Tp}$ \\
\hline UE 25 WT 17 & $\overline{\mathrm{DSC}}, 1994$ & $\mathrm{Tc}, \mathrm{P}, \mathrm{Tp}$ \\
\hline UE 25 WT 18 & DSC, 1994 & $\mathrm{Tc}, \mathrm{P}, \mathrm{Tp}$ \\
\hline UE 25 UZ 4 & DSC, 1994 & $\mathrm{Tc}, \mathrm{P}, \mathrm{Tp}$ \\
\hline UE 25 UZ 5 & DSC, 1994 & Tc, $\mathrm{P}$ \\
\hline USW GA 1 & DSC, 1994 & Tc \\
\hline USW G1 & SAND 84-2668 & $\mathrm{Tp}$ \\
\hline USW G2 & SAND 84-2668 & $\mathrm{Tc}, \mathrm{P}, \mathrm{Tp}$ \\
\hline USW G3 & OFR 84-791 & $\mathrm{Tc}, \mathrm{P}, \mathrm{Tp}$ \\
\hline USW GU 3 & OFR 84-791 & $\mathrm{Tc}, \mathrm{P}, \mathrm{Tp}$ \\
\hline USW G4 & $\begin{array}{l}\text { OFR 84-789 } \\
\text { OFR 84-063 }\end{array}$ & Tc, P, Tp \\
\hline USW H1 & $\begin{array}{c}\text { OFR 83-141 } \\
\text { OFR 84-4032 }\end{array}$ & $\mathrm{P}, \mathrm{Tp}$ \\
\hline USW H3 & $\begin{array}{c}\text { OFR } 84-149 \\
\text { WRIR } 84-4272\end{array}$ & $\mathrm{Tc}_{\mathrm{c}} \mathrm{P}, \mathrm{Tp}$ \\
\hline USW H4 & $\begin{array}{c}\text { OFR 84-449 } \\
\text { WRIR 83-4030 }\end{array}$ & $\mathrm{Tc}, \mathrm{P}, \mathrm{Tp}$ \\
\hline USW H5 & OFR 83-853 & $\mathrm{Tc}, \mathrm{P}, \mathrm{Tp}$ \\
\hline USW H6 & OFR 83-856 & P, Tp \\
\hline USW UZ1 & OFR 90-351 & Tc \\
\hline USW UZ6 & DSC, 1994 & $\mathrm{Tc}, \mathrm{P}, \mathrm{Tp}$ \\
\hline USW UZ7 & OFR 88-465 & Tc, $\mathrm{P}$ \\
\hline USW UZ13 & OFR 90-362 & $\mathrm{P}$ \\
\hline USW WT1 & DSC, 1994 & $\mathrm{Tc}, \mathrm{P}, \mathrm{Tp}$ \\
\hline USW WT2 & DSC, 1994 & $\mathrm{Tc}, \mathrm{P}, \mathrm{Tp}$ \\
\hline \multicolumn{3}{|c|}{$\begin{array}{ll}\text { Caption: } & - \text { OFR, SAND, WRIR }=\text { reports, see reference list } \\
& \text { in Appendix A. DSC = Draft Stratigraphic Compendium, by M\&O, } \\
& \text { 1994. } \\
& - \text { Tc }=\text { Tiva Canyon; } \mathrm{P}=\text { Paintbrush; } \mathrm{Tp}=\text { Topopah Spring. }\end{array}$} \\
\hline
\end{tabular}


Table D. Depths to bottom of geological layers, elevations of hydrogeological unit boundaries, thickness, and water table data for the 34 boreholes used in the grid design.

\begin{tabular}{|c|c|c|c|c|c|c|c|}
\hline & $\begin{array}{c}\text { elevation } \\
\text { m.a.s.1. }\end{array}$ & $\begin{array}{l}\text { water } \\
\text { depth } \\
\text { m.b.g. }\end{array}$ & $\begin{array}{c}\text { watertable } \\
\text { m.a.s.l. }\end{array}$ & $\begin{array}{l}\text { Tot. } \\
\text { depth } \\
\text { m.b.g. }\end{array}$ & $\begin{array}{l}\text { vitric/ } \\
\text { zeol. } \\
\text { m.b.g. }\end{array}$ & $\begin{array}{c}\text { alluvium } \\
\mathrm{mb} . \mathrm{g}\end{array}$ & $\begin{array}{l}\text { Rain. } \\
\text { Mesa } \\
\text { m.b.g. }\end{array}$ \\
\hline UE 25 a1 & 1199.2 & 468.2 & 731 & 762.4 & 415.7 & 9.1 & \\
\hline UE 25 a4 & 1250.2 & & & 152.4 & & 9.1 & \\
\hline UE 25 a5 & 1236.7 & & & 148.5 & & 27.4 & \\
\hline UE 25 a6 & 1235.4 & & & 152.4 & & 6.1 & \\
\hline UE 25 a7 & 1220.9 & & & 137 & & 41.9 & \\
\hline UE $25 \mathrm{~b} 1$ & 1200.7 & 470 & 730.7 & 1219.9 & 422.2 & 45.7 & \\
\hline UE $25 \mathrm{C} 1$ & 1130.6 & 400.6 & 730 & 914.6 & 398.8 & & \\
\hline UE $25 \mathrm{C} 2$ & 1132.3 & & & 914.6 & 393 & 21.3 & \\
\hline UE 25 C3 & 1132.4 & & & 914.6 & 387.2 & 24.4 & \\
\hline UE 25 p1 & 1114.2 & 361.7 & 752.5 & 1805 & 352 & 39 & 52 \\
\hline UE 25 WT4 & 1169.2 & 438.5 & 730.7 & 481.6 & 334.4 & 15.5 & \\
\hline UE 25 WT6 & 1314.8 & 279.7 & 1035.1 & 383 & 368.8 & 51.8 & \\
\hline UE 25 WT16 & 1210.6 & 472.3 & 738.3 & 520.9 & $?$ & 41.8 & \\
\hline UE 25 WT17 & 1124.1 & 394 & 730.1 & 442.1 & $?$ & & \\
\hline UE 25 WT18 & 1336.3 & & & 622.7 & 475.2 & & \\
\hline UE 25 UZ4 & 1278.4 & & & 111.8 & & & \\
\hline UE 25 UZ5 & 1204.8 & & & 110.6 & $?$ & & \\
\hline USW GA1 & 1581.3 & & & 150.9 & $?$ & & \\
\hline USW G1 & 1325.8 & 572 & 753.8 & 1829.3 & 421.1 & 18.3 & \\
\hline USW G2 & 1553.9 & 524.9 & 1029 & 1830.9 & 518.6 & & \\
\hline USW G3 & 1480.5 & 749.9 & 730.6 & 1533.9 & & & \\
\hline USW GU3 & 1480.7 & & & 805.9 & 607.1 & & \\
\hline USW G4 & 1270.1 & 539.1 & 731 & 914.7 & 420 & 6.7 & \\
\hline USW H1 & 1303.1 & 572.1 & 731 & 1829 & 459 & & \\
\hline USW H3 & 1483.5 & 751.8 & 731.7 & 1219 & 521.2 & & \\
\hline USW H4 & 1248.7 & 518.4 & 730.3 & 1219.4 & 392 & & \\
\hline USW H5 & 1478.9 & 703.4 & 775.5 & 1219.2 & 647.7 & & \\
\hline USW H6 & 1302.1 & 526 & 776.1 & 1219.9 & 512.1 & 9.1 & \\
\hline USW UZ1 & 1349.5 & & & 387.1 & & 17.4 & \\
\hline USW UZ6 & 1501.2 & & & 575.2 & & & \\
\hline USW UZ7 & 1271.1 & & & 62.9 & & 6.7 & \\
\hline USW UZ13 & 1468.2 & & & 130.9 & & & \\
\hline USW WT1 & 1201 & 470.7 & 730.3 & 514.8 & 418.8 & 9.1 & \\
\hline USW WT2 & 1301.1 & 570.3 & 730.8 & 627.9 & 463.3 & 18.3 & \\
\hline
\end{tabular}


Table D. Elevations of hydrogeological unit boundaries, thickness, and water table data for the 34 boreholes used in the grid design (continued).

\begin{tabular}{|c|c|c|c|c|c|c|c|}
\hline (continued) & $\begin{array}{l}\text { Tiva w. } \\
\text { m.b.g. }\end{array}$ & $\begin{array}{l}\text { Tiva elev. } \\
\text { ma.s. }\end{array}$ & $\begin{array}{l}\text { Tiva-Hy- } \\
\text { dro thick- } \\
\text { ness } m \text {. }\end{array}$ & $\begin{array}{l}\text { Tiva } \\
\text { n.-w. } \\
\text { m.b.g. }\end{array}$ & $\begin{array}{l}\text { bedded } \\
\text { t. m.b.g. }\end{array}$ & $\begin{array}{l}\text { Yucca } \\
\text { n.-w. } \\
\text { m.b.g. }\end{array}$ & $\begin{array}{l}\text { Yucca } \\
\text { w. } \\
\text { m.b.g. }\end{array}$ \\
\hline UE 25 a 1 & 59.4 & 1139.8 & 50.3 & 73 & 82.3 & & \\
\hline UE 25 a 4 & 36.9 & 1213.3 & 27.8 & 45.9 & 46.6 & 54.6 & \\
\hline UE 25 a5 & 39 & 1197.7 & 11.6 & 42.3 & & 50.9 & \\
\hline UE 25 a 6 & 37.5 & 1197.9 & 31.4 & 44 & 45.5 & 51.6 & \\
\hline UE 25 a7 & 47.5 & 1173.4 & 5.6 & 52.1 & 53.2 & 59.3 & \\
\hline $\mathrm{UE} 25 \mathrm{~b} 1$ & 64 & 1136.7 & 18.3 & 73.1 & & & \\
\hline UE $25 \mathrm{Cl}$ & 79.3 & 1051.3 & 70.3 & 93 & 96 & & \\
\hline UE $25 \mathrm{C} 2$ & 76.2 & 1056.1 & 54.9 & & 88.4 & & \\
\hline UE $25 \mathrm{C} 3$ & 68.6 & 1063.8 & 44.2 & & 88.4 & & \\
\hline UE 25 p1 & 81 & 1033.2 & & & & & \\
\hline UE 25 WT4 & 82.3 & 1086.9 & 66.8 & 85 & 86.3 & 94.8 & \\
\hline \multicolumn{8}{|l|}{ UE 25 WT6 } \\
\hline UE 25 WT16 & 113.7 & 1096.9 & 71.9 & 122.2 & 138.7 & & \\
\hline UE 25 WT17 & 74.7 & 1049.4 & 74.7 & & & & \\
\hline UE 25 WT18 & 93 & 1243.3 & 93 & 104.5 & 110 & 128.9 & \\
\hline UE 25 UZ4 & 26.1 & 1252.3 & 26.1 & & 32.3 & 46.6 & \\
\hline UE 25 UZ5 & 27.4 & 1168.6 & 27.4 & & 37.2 & 50.6 & \\
\hline USW GA1 & 63 & 1518.3 & 63 & 68.4 & 74.2 & 101.2 & \\
\hline USW G1 & & & & 30.5 & 41.1 & & \\
\hline USW G2 & 60.9 & 1493 & 60.9 & 68.6 & 74.7 & 79.3 & 102.5 \\
\hline \multicolumn{8}{|l|}{ USW G3 } \\
\hline USW GU3 & 108 & 1370.7 & & 113.9 & 129.2 & & \\
\hline USW G4 & 36 & 1234.1 & 29.3 & 42.1 & 45.1 & & \\
\hline USW H1 & & & & 27 & 29 & 49 & \\
\hline USW H3 & 106.7 & 1376.8 & 106.7 & 119.5 & 123.1 & & \\
\hline USW H4 & 53 & 1195.7 & 53 & 61.6 & 65.2 & & \\
\hline USW H5 & 118.9 & 1360 & 118.9 & 147.8 & 149.4 & & \\
\hline USW H6 & 61 & 1241.1 & 51.9 & 79.3 & 82.3 & & \\
\hline USW UZ1 & 20.7 & 1328.8 & 3.3 & 25.6 & 32 & & \\
\hline USW UZ6 & 126.5 & 1373.2 & 128 & & & 147.4 & \\
\hline USW UZ7 & 27.4 & 1243.7 & 20.7 & 34.8 & 40.7 & & \\
\hline USW UZ13 & 100.3 & 1367.9 & 100.3 & 107.9 & 114 & & \\
\hline USW WT1 & 120.4 & 1080.6 & 111.3 & 132.3 & 144.2 & & \\
\hline USW WT2 & 61 & 1240.1 & 42.7 & 79.2 & 82.3 & & \\
\hline
\end{tabular}


Table D. Elevations of hydrogeological unit boundaries, thickness, and water table data for the 34 boreholes used in the grid design (continued).

\begin{tabular}{|c|c|c|c|c|c|c|c|}
\hline (continued) & $\begin{array}{l}\text { Yucca } \\
\text { n.-w. } \\
\text { m.b.g. }\end{array}$ & $\begin{array}{l}\text { bedded } t \text {. } \\
\text { m.b.g. }\end{array}$ & $\begin{array}{l}\text { Pah n.-w. } \\
\text { mb.g. }\end{array}$ & $\begin{array}{c}\text { bedded } \mathrm{t} . \\
\text { m.b.g. }\end{array}$ & $\begin{array}{l}\text { Topo. } \\
\text { n.-w. } \\
\text { m.b.g. }\end{array}$ & $\begin{array}{l}\text { Paint-Hydro } \\
\text { thickness m. }\end{array}$ & $\begin{array}{l}\text { Topo w. } \\
\text { m.b.g. }\end{array}$ \\
\hline UE 25 a1 & & & & & 84 & 24.6 & 401.5 \\
\hline UE $25 \mathrm{a} 4$ & & 58.2 & 83.8 & 85.4 & 96.6 & 59.7 & TD 152.4 \\
\hline UE 25 a5 & & 56.5 & 70 & 72.3 & 84.5 & 45.5 & TD 148.5 \\
\hline UE 25 a6 & & 57.4 & 61.5 & 69.2 & 73.7 & 36.2 & TD 152.4 \\
\hline UE 25 a7 & & 60.3 & 72.8 & 74.7 & 83.4 & 35.9 & TD 137.0 \\
\hline UE 25 b1 & & & 79.2 & 83.8 & & 19.8 & 405.4 \\
\hline UE 25 C1 & & & & & 98.5 & 19.2 & 398.8 \\
\hline UE 25 C2 & & & & & 96.6 & 20.4 & 393 \\
\hline UE 25 C 3 & & & & & 89.9 & 21.3 & 387.2 \\
\hline UE 25 p1 & & & & & & 0 & 381 \\
\hline UE 25 WT4 & & 103.3 & 121.6 & 132 & 138.7 & 56.4 & 343.5 \\
\hline UE 25 WT6 & & & & & & 0 & 107.3 \\
\hline UE 25 W'T16 & & & 173.1 & 175.3 & 181.4 & 67.7 & 319.7 \\
\hline UE 25 WT17 & & & & & & 0 & 289.5 \\
\hline UE 25 WT18 & & 146.3 & 168.6 & 212.4 & 218.7 & 120.7 & 475.2 \\
\hline UE 25 UZ4 & & 53 & 86.3 & & TD 111.8 & & \\
\hline UE 25 UZ5 & & 57.9 & 94.8 & 101.5 & TD 109.5 & 81.7 & TD 110.6 \\
\hline USW GA1 & & 142.7 & & & TD 150.9 & & \\
\hline USW G1 & & & & & 82.3 & -alluvium & 409.1 \\
\hline USW G2 & 148.7 & 151.8 & 222.7 & 231.5 & 232.2 & 171.3 & 512.4 \\
\hline USW G3 & & & & & & $?$ & \\
\hline USW GU3 & & & & & 130.4 & 22.4 & 396 \\
\hline USW G4 & & 51.3 & 57.3 & 69.5 & 72.8 & 36.8 & 410.1 \\
\hline USW H1 & & 58 & 85 & $?$ & $?$ & 85 & 454 \\
\hline USW H3 & & & & & 134.7 & 28 & 420.6 \\
\hline USW H4 & & & & & 76.8 & 23.8 & 370.9 \\
\hline USW H5 & & & 163.1 & 165.2 & 173.1 & 54.2 & 504.4 \\
\hline USW H6 & & & 88.4 & 91.5 & 100.6 & 39.6 & 398.3 \\
\hline USW UZ1 & & & 71.6 & 77.7 & 86.3 & $>65.6$ & TD 387.1 \\
\hline USW UZ6 & & & & & & 19.4 & $? 438$ \\
\hline USW UZ7 & & & 42 & 48.8 & 52.4 & 25 & TD 62.9 \\
\hline USW UZ13 & & & & & 121.3 & 21 & TD 130.9 \\
\hline USW WT1 & & & & & 149 & 28.6 & 409 \\
\hline USW WT2 & & & & & 85.6 & 24.6 & 372.5 \\
\hline
\end{tabular}


Table D. Elevations of hydrogeological unit boundaries, thickness, and water table data for the 34 boreholes used in the grid design (continued).

\begin{tabular}{|c|c|c|c|c|c|c|c|}
\hline (continued) & $\begin{array}{l}\text { Topo-Hydro, } \\
\text { thickness m. }\end{array}$ & $\begin{array}{l}\text { Topo. n-- } \\
\text { w m b.g. }\end{array}$ & $\begin{array}{l}\text { bedded } \mathrm{t} \\
\mathrm{m} \cdot \mathrm{b} . \mathrm{g}\end{array}$ & $\begin{array}{l}\text { Calico n.-w. } \\
\text { m.b.g. }\end{array}$ & $\begin{array}{l}\text { bedded } \mathrm{t} \\
\text { m.b.g. }\end{array}$ & $\begin{array}{l}\text { Prown.-w. } \\
\text { m.b.g. }\end{array}$ & $\begin{array}{l}\text { Prow w. } \\
\text { m.b.g. }\end{array}$ \\
\hline UE 25 a1 & 317.5 & 414.5 & 415.7 & 560 & & 711.3 & \\
\hline \multicolumn{8}{|l|}{ UE 25 a 4} \\
\hline \multicolumn{8}{|l|}{ UE 25 a5 } \\
\hline \multicolumn{8}{|l|}{ UE 25 a6 } \\
\hline \multicolumn{8}{|l|}{ UE 25 a7 } \\
\hline UE 25 b1 & 321.6 & 411.5 & 422.2 & 560.8 & 596.7 & 718 & \\
\hline UE $25 \mathrm{C} 1$ & 300.3 & 407 & $?$ & 515.9 & $?$ & 646 & \\
\hline UE $25 \mathrm{C} 2$ & 296.4 & 401.2 & $?$ & 509.5 & ? & 651.8 & \\
\hline UE $25 \mathrm{C} 3$ & 297.3 & 396.3 & $?$ & 497 & $?$ & 643 & \\
\hline UE $25 \mathrm{pl}$ & 300 & & & 422 & 436 & 546 & \\
\hline UE 25 WT4 & 204.8 & 351.1 & 351.7 & TD 481.6 & & & \\
\hline UE 25 WT6 & -alluvium & 112.5 & 116.7 & TD 383.0 & & & \\
\hline UE 25 WT16 & 138.3 & 325.5 & & TD 520.9 & & & \\
\hline UE 25 WT17 & 225.6 & & & 371.3 & & TD 442.1 & \\
\hline UE 25 WT18 & 261.5 & 493.8 & & $\downarrow \mathrm{TD} 622.7$ & & & \\
\hline \multicolumn{8}{|l|}{ UE 25 UZ4 } \\
\hline \multicolumn{8}{|l|}{ UE 25 UZ5 } \\
\hline \multicolumn{8}{|l|}{ USW GA1 } \\
\hline USW G1 & 326.8 & 427.8 & 434.4 & $\downarrow 529.1$ & 549 & 656.4 & \\
\hline USW G2 & 280.2 & 518.5 & 535.5 & $\downarrow 824.2$ & $?$ & 990.1 & \\
\hline USW G3 & $?$ & & & & & $\downarrow$ & \\
\hline USW GU3 & 265.6 & 428.7 & 430.6 & 459.3 & 475.6 & 607.1 & \\
\hline USW G4 & 337.3 & 428.8 & 429.6 & 519.8 & 536.9 & 682 & \\
\hline USW H1 & 369 & & 459 & 549 & 566 & 701 & \\
\hline USW H3 & 285.9 & 424.3 & & 438 & 453.2 & 579.1 & \\
\hline USW H4 & 294.1 & 399.9 & & 480.1 & 495.9 & 689.8 & \\
\hline USW H5 & 331.3 & 517.9 & 521.2 & 573 & 592.8 & 682.8 & \\
\hline USW H6 & 297.7 & 410.3 & 419.5 & 444.4 & 458.4 & 538 & \\
\hline \multicolumn{8}{|l|}{ USW UZ1 } \\
\hline USW UZ6 & 290.6 & & & 483 & & TD 575.2 & \\
\hline \multicolumn{8}{|l|}{ USW UZ7 } \\
\hline \multicolumn{8}{|l|}{ USW UZ13 } \\
\hline USW WT1 & 260 & 418.8 & 421.8 & TD 514.8 & & & \\
\hline USW WT2 & 286.9 & 394.1 & 397.2 & 463.3 & 485.8 & 615.7 & TD 627.9 \\
\hline
\end{tabular}


Table D. Elevations of hydrogeological unit boundaries, thickness, and water table data for the 34 boreholes used in the grid design (continued).

\begin{tabular}{|c|c|c|c|c|c|c|c|}
\hline (continued) & $\begin{array}{l}\text { bedded t. } \\
\text { m.b.g. }\end{array}$ & $\begin{array}{c}\text { Bullf.n.-w. } \\
\text { m.b.g. }\end{array}$ & $\begin{array}{l}\text { Bullfrog } \\
\text { w. m.b.g. }\end{array}$ & $\begin{array}{l}\text { Bull.n.-w. } \\
\text { m.b.g. }\end{array}$ & $\begin{array}{c}\text { bedded } t \\
\text { m.b.g. }\end{array}$ & $\begin{array}{l}\text { Tram n.-w. } \\
\text { m.b.g. }\end{array}$ & $\begin{array}{l}\text { bedded } t \\
\text { m.b.g. }\end{array}$ \\
\hline $\mathrm{UE} 25$ a1 & & TD 762.4 & & & & & \\
\hline \multicolumn{8}{|l|}{ UE 25 a4 } \\
\hline \multicolumn{8}{|l|}{ UE 25 a5 } \\
\hline \multicolumn{8}{|l|}{ UE 25 a6 } \\
\hline \multicolumn{8}{|l|}{ UE 25 a7 } \\
\hline UE 25 b1 & 719.7 & 869.5 & & & 878.6 & & \\
\hline UE $25 \mathrm{Cl}$ & $?$ & 821.6 & 828 & TD 914.6 & & & \\
\hline UE $25 \mathrm{C} 2$ & $?$ & 829 & $?$ & TD 914.6 & & & \\
\hline UE 25 C3 & $?$ & 814 & $?$ & TD 914.6 & & & \\
\hline UE $25 \mathrm{p} 1$ & 558 & 683 & & & 690 & & \\
\hline \multicolumn{8}{|l|}{ UE 25 WT4 } \\
\hline \multicolumn{8}{|l|}{ UE 25 WT6 } \\
\hline \multicolumn{8}{|l|}{ UE 25 WT16 } \\
\hline \multicolumn{8}{|l|}{ UE 25 WT17 } \\
\hline \multicolumn{8}{|l|}{ UE 25 WT18 } \\
\hline \multicolumn{8}{|l|}{ UE 25 UZ4 } \\
\hline \multicolumn{8}{|l|}{ UE 25 UZ5 } \\
\hline \multicolumn{8}{|l|}{ USW GA1 } \\
\hline USW G1 & 662.5 & 793.2 & & & 804.7 & & \\
\hline USW G2 & 1000.4 & 1067.9 & & & 1089.4 & & \\
\hline USW G3 & & & $\downarrow$ & & 800.2 & & \\
\hline USW GU3 & 611.1 & 666 & 776 & 797.7 & 803.8 & & \\
\hline USW G4 & 684 & 780 & & & 839.9 & TD 914.7 & \\
\hline USW H1 & 707 & 820 & & & 832 & & \\
\hline USW H3 & 581.3 & 609.6 & 708.1 & 746.5 & $\downarrow \quad 755$ & 1095.8 & 1108.6 \\
\hline USW H4 & 693.4 & 806 & & & 812.1 & 1154.7 & 1164.2 \\
\hline USW H5 & 689.8 & 826.9 & & & 835.8 & 1040 & 1043 \\
\hline USW H6 & 574.1 & 678.2 & & & 687.3 & 874.5 & 877.2 \\
\hline \multicolumn{8}{|l|}{ USW UZ1 } \\
\hline \multicolumn{8}{|l|}{ USW UZ6 } \\
\hline \multicolumn{8}{|l|}{ USW UZ7 } \\
\hline \multicolumn{8}{|l|}{ USW UZ13 } \\
\hline \multicolumn{8}{|l|}{ USW WT1 } \\
\hline USW WT2 & & & & & & & \\
\hline
\end{tabular}


Table D. Elevations of hydrogeological unit boundaries, thickness, and water table data for the 34 boreholes used in the grid design (continued).

\begin{tabular}{|c|c|c|c|c|c|}
\hline (continued) & $\begin{array}{l}\text { control } \\
\text { m.a.s.l. }\end{array}$ & $\begin{array}{l}\text { Topo. elev. } \\
\text { m.a.s.l. }\end{array}$ & $\begin{array}{c}\text { Unsat.thick. } \\
\mathrm{m} .\end{array}$ & $\begin{array}{c}\text { Calico thick. } \\
\mathrm{m}\end{array}$ & $\begin{array}{c}\text { Vitr-zeol. elev } \\
\text { m.a.s.l. }\end{array}$ \\
\hline UE 25 a1 & $\overline{436.8}$ & $\overline{797.7}$ & 469.2 & $\overline{67.7}$ & $\overline{783.5}$ \\
\hline $\mathrm{UE} 25$ a4 & 1097.8 & & & & \\
\hline UE 25 a5 & 1088.2 & & & & \\
\hline UE 25 a6 & $\overline{1083.0}$ & & & & \\
\hline UE 25 a 7 & 1083.9 & & & & \\
\hline UE 25 b1 & -19.2 & 795.3 & 470.7 & $\overline{65.3}$ & 778.5 \\
\hline UE $25 \mathrm{C} 1$ & 216.0 & 731.8 & 400.6 & 1.8 & 731.8 \\
\hline UE 25 C2 & 217.7 & $\overline{739.3}$ & 402.3 & 9.3 & 739.3 \\
\hline UE $25 \mathrm{C} 3$ & 217.8 & 745.2 & 402.4 & 15.2 & 745.2 \\
\hline UE 25 p1 & -690.8 & 723.2 & 384.2 & -6.8 & 762.2 \\
\hline UE 25 WT4 & 687.6 & 825.7 & & & 834.8 \\
\hline UE 25 WT6 & 931.8 & 1155.7 & & & 946.0 \\
\hline UE 25 WT16 & 689.7 & 889.3 & & & \\
\hline UE 25 WT17 & 682.0 & 823.8 & & & \\
\hline UE 25 WT18 & 713.6 & 861.1 & & & 861.1 \\
\hline UE 25 UZ4 & 1166.6 & & & & \\
\hline UE 25 UZ5 & 1094.2 & & & & \\
\hline USW GA1 & 1430.4 & & & & \\
\hline USW G1 & -503.5 & 892.9 & 595.8 & 162.9 & 904.7 \\
\hline USW G2 & -277.0 & 1041.5 & 823.9 & 311.5 & 1035.3 \\
\hline USW G3 & -53.4 & & & & \\
\hline USW GU3 & 674.8 & 1084.7 & 750.7 & 354.7 & 873.6 \\
\hline USW G4 & 355.4 & 860.0 & 540.1 & 130.0 & 850.1 \\
\hline USW H1 & -525.9 & 849.1 & 573.1 & 119.1 & 844.1 \\
\hline USW H3 & 264.5 & 1062.9 & 753.5 & 332.9 & 962.3 \\
\hline USW H4 & 29.3 & 877.8 & 518.7 & 147.8 & 856.7 \\
\hline USW H5 & 259.7 & 974.5 & 748.9 & 244.5 & 831.2 \\
\hline USW H6 & 82.2 & 903.8 & 572.1 & 173.8 & 790.0 \\
\hline USW UZ1 & 962.4 & & & & \\
\hline USW UZ6 & 926.0 & & & & \\
\hline USW UZ7 & 1208.2 & & & & \\
\hline USW UZ13 & 1337.3 & & & & \\
\hline USW WT1 & 686.2 & & & & 782.2 \\
\hline USW WT2 & 673.2 & & & & $\overline{837.8}$ \\
\hline
\end{tabular}

